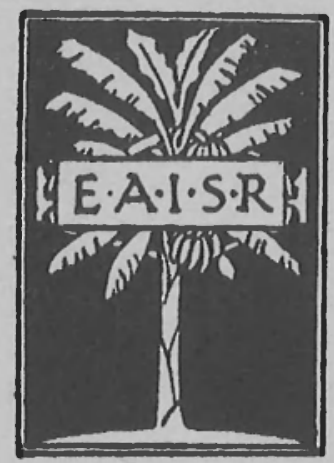

\title{
THE TRADE OF
}

\section{LAKE VICTORIA}

V. C. R. FOR D

EAST AFRICAN STUDIES NO. 3 


\title{
EAST AFRICAN STUDIES
}

\author{
DISTRIBUTION \\ In East Africa \\ EAST AFRICAN LITERATURE BUREAU
}

P.O. BOX 2022, NAIROBI, KENYA

Outside East Africa

KEGAN PAUL TRENCH TRUBNER \& CO. LTD.

43 GREAT RUSSELL STREET

LONDON, W.C.1

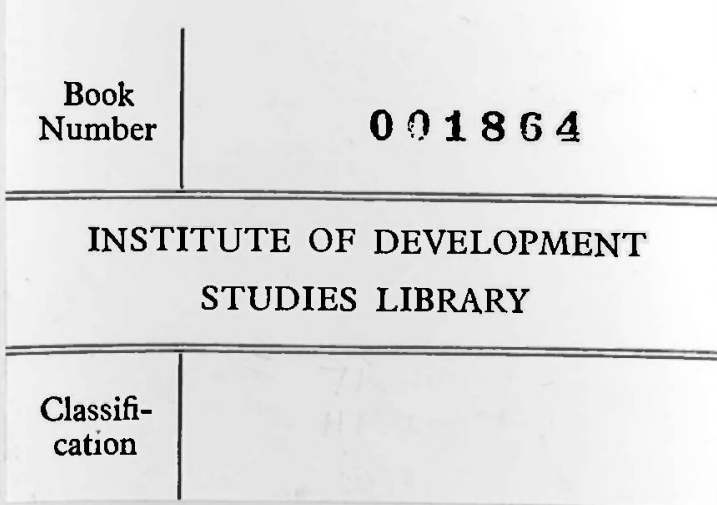




\section{EAST AFRICAN STUDIES}

Already published

No. 1. Land Tenure in Buganda, by A. B. Mukwaya. 2 s.

No. 2. The Indigenous Political System of the Sukuma, by H. Cory. 3s. 6d.

No. 3. The Trade of Lake Victoria, A Geographical Study, by V. C. R. Ford. $11 \mathrm{~s}$.

Forthcoming Titles

JinJa TRANSFormed, by C. and R. Sofer.

Labour Migration in Southern Tanganyika, by P. Gulliver.

\section{EAST AFRICAN LINGUISTIC STUDIES}

No. 1. An Introduction to the Study of Iraqw, by W. H. Whiteley. 10s. 6d.

\section{OTHER PUBLICATIONS}

Already published

Economic Development and Tribal Change, edited by A. I. Richards. 30s. Cambridge. Heffers. 1954.

\section{Forthcoming}

Bwamba : A Structural-Functional Analysis of a Patrilineal Society, by E. H. Winter. Cambridge. Heffers.

Alur SocieTY: A Study of Processes and Types of Domination, by A. W. Southall. Cambridge. Heffers.

Bantu Bureaucracy : A Study of Conflict and Change in the Political Institutions of an East African People, by L. A. Fallers. Cambridge. Heffers.

Orders for the whole series may be placed with the following :-

East African Literature Bureau, P.O. Box 2022 , Nairobi, or Messrs. Kegan Paul Trench Trubner \& Co., Ltd., 43 Gt, Russell St., W.C.1. 


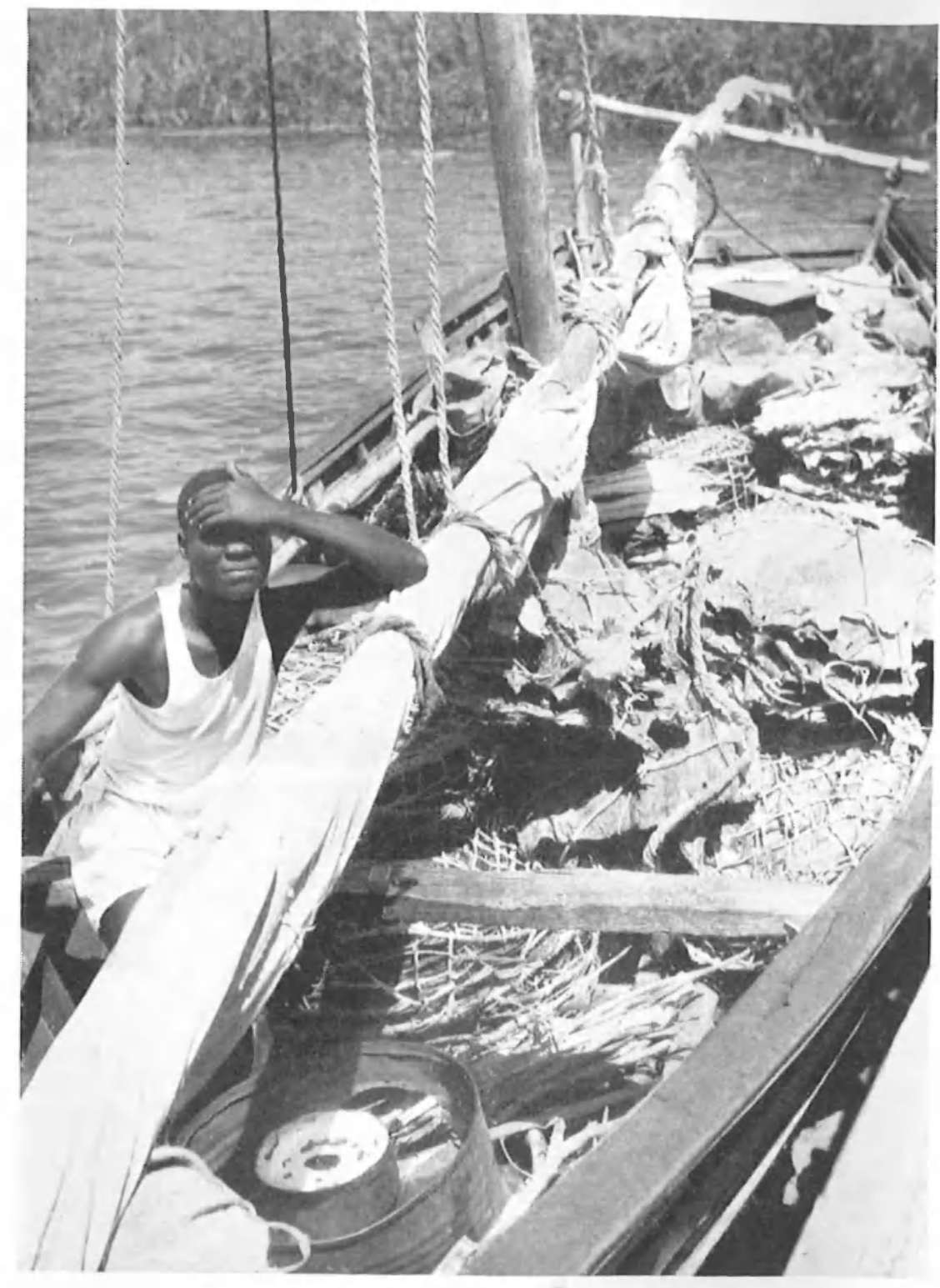

1 Fishing karua, Asembo Bay, Central Nyanza Kenya Colony. This small dhow is loaded with dried "ngege" and lung-fish brought from the Speke Gulf and Baumann Gulf. Note the lack of any accommodation for the crew and the typical galley, an old tin can filled with earth. The roural wheel-shaped baskets containing the dried ngege are to be seen as well as the more shapeless bundles of dried lung-fish. 


\section{THE TR A D E O F}

\section{A K E V I C T O R I A}

A GEOGRAPHICAL STUDY

BY

V. C. R. FOR D, M.A.

Lecturer in Geography in the Queen's University of Belfast

(Formerly Lecturer in Geography in the University College of East Africa)

\begin{tabular}{|c|}
\hline INSTITUTE \\
OF \\
DEVELOPMENT \\
STUDIES \\
LIDRARY
\end{tabular}

1

EAST AFRICAN INSTITUTE OF SOCIAL RESEARCH, KAMPALA, UGANDA 


\section{P R E F A C E}

$\mathrm{T}$ HE marginal lands of Lake Victoria are some of the most densely populated and most highly productive in East Africa. The trade of these lands has played a major role in the economy of the two British dependencies, Kenya Colony and the Uganda Protectorate, and the British mandated territory of Tanganyika. In 1947 with the approaching establishment of an East African High Commission and the amalgamation of certain services common to East Africa, it seemed opportune for a survey of the trade of Lake Victoria to be made. This survey was completed in 1950 when it was presented as a thesis for the M.A. degree of the University of London. The original work has now been revised and abridged slightly.

The work has been done chiefly in two ways. First, by study of the records kept in the headquarters in Nairobi of the Kenya and Uganda Railways and Harbours section of the East African Railways and Harbours. In particular, use has been made of the Hollerith data for the years 1948 and 1952. These statistics record every movement of goods, however small, indicating in code the place of origin, the place of destination, the type of commodity, its rate class and the amount of revenue earned. All weights are recorded in pounds and values in cents. Secondly, a protracted journey was made by boat, car and at times by foot, around the lake in the period January to March 1949. The opportunity was taken of seeing at first hand something of the regions from which the lake traffic is derived and of talking to government officers and of reading some of the great wealth of material which lies unpublished and buried in innumerable files in government offices. Use has also been made of material in the Colonial Office Library not easily accessible in East Africa.

The Annual Reports of the Uganda Railway, later the Kenya and Uganda Railways, have been a source of much statistical information. The early reports give very detailed statistical information but changes in format have prevented complete records from being available throughout the period under review. In many cases the figures have been declared to be approximate only, and frequent discrepancies have been encountered. Nevertheless these approximate figures, as they were the only ones available in detail for each port, have had to be used for compiling the maps.

At times data have been available from several sources, e.g. the railway, the customs and the agricultural departments. With no indication of their basis of compilation, these figures have frequently been greatly at variance and the choice has had to be made of the most likely set of figures as circumstances dictated. The joint customs union of Kenya and Uganda did not publish its returns in a manner which allowed the trade of the two countries to be separated, and it was not possible to estimate on a customs basis the lake trade between Kenya and Uganda. Likewise the habit of the Tanganyika Customs posts of not differentiating between the Kenya and Uganda traffic, but of recording it jointly, defeated detailed analysis. The official Trade Reports of the three territories do not distingus the traffic at individual ports, but consolidate ocean, lake and train returns under one head.

The two dhow traffic maps have been drawn from statistics obtained from the very detailed files which have been kept for over twenty years in the Nairobi headquarters of the railway. In the period 1933-1940 the dhow industry, although an organisation without official support, presented a serious challenge to the railway boats on Lake Victoria. The dhow traffic was essentially a phenomenon of the years between 1926 and 1940. This was a period when the littoral of Lake Victoria was developing and was also a 
period when rating differences between the two railway systems of East Africa made conditions favourable for the growth of a competitive form of transport. Although the dhow traffic forms a side chapter in the main history of the trade of the lake, the full story cannot be understood without an account of the brief period of the importance of the dhows. The very close documentation of the dhow trade is the result of its history and reflects the serious view then taken by the Kenya and Uganda Railways of this alternative form of transport.

It remains to acknowledge the help of all those who have made it possible to write and publish this work. I am greatly indebted both to the Research Grants Committee of Makerere College and to the East African Institute of Social Research for jointly sharing the cost of publication. To the Council of Makerere College I must express my gratitude for a term's leave of absence to enable the material to be presented to the University of London, and for generous help towards the cost of the fieldwork. My senior colleague, Professor S. J. K. Baker, M.A., who suggested the subject, has at all times given gladly and generously of his advice and time, and his criticism and above all his encouragement are very gratefully recorded. The final form of the maps is the result of the many hours of careful work by the draughtsman of the Geography Department of Makerere College, Mr. A. Serubiri, whose patience in interpreting my pencilled draughts should be placed on record. Grateful acknowledgements are made to George Philip and Son Ltd., for permission to reproduce the map of place names from the essay "The Trade of Lake Victoria and its Marginal Lands", published in their book Geographical Essays on British Tropical Lands, and to draw heavily upon that essay for the content of the fourth chapter of this book. Much is owed to the help given by many officials of the East African Railways and Harbours, and for their permission to examine records stored in Nairobi, in particular Sir Reginald E. Robins, C.M.G., O.B.E., the former Member for Transport in the East African High Commission, J. H. Collier-Wright, Esq., M.A., and to the personnel of the Rating Section. The number of government officers whose time and good nature were trespassed upon is legion, but in particular the following should be mentioned : T. S. Jervis, Esq., N. V. Rounce, Esq., and the late W. Lynne-Watt, Esq., M.B.E., all of the Colonial Agricultural Service, the District Commissioners of Bukoba and Musoma and the Customs Officers at Bukoba, Mwanza, and Musoma. Finally, to my sister, Miss W. M. Ford, B.A., I would like to make acknowledgment for the very great help she has given in many hours of careful criticism and proof-reading.

Belfast,

June 1955.

V.C.R.F. 


\section{TABLE OF CONTENTS}

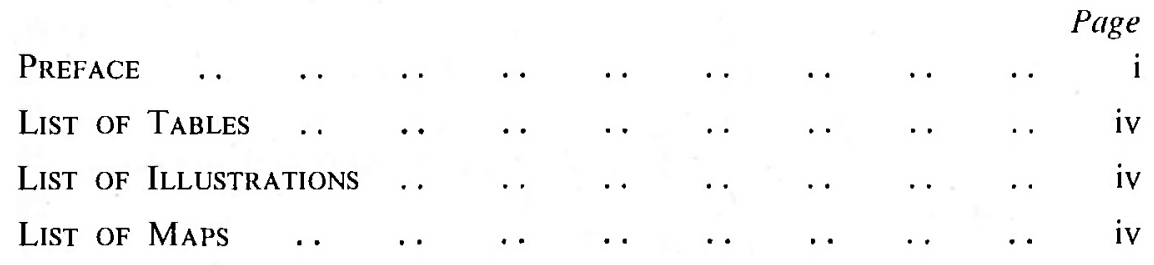

Chapter

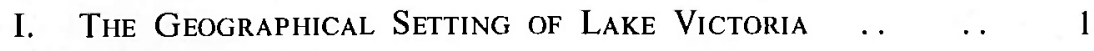

Size and Position

Relief and Drainage of the Lake Plateau

The Coastline and the Islands of Lake Victoria

The Climates of the Lands Marginal to Lake Victoria

The Vegetation Divisions of the Lake Basin

Limits of the "Lake Victoria " Zone

The Bukoba Region

The Basin of the Middle and Lower Kagera River

The Southern Buganda and Busoga Region

The Nyanza Region

The Musoma Region

The Mwanza Region

II. The Historical Geograpily of the Trade of lake $\begin{array}{llllllllll}\text { VICTORIA } & . & \ldots & \ldots & \ldots & \ldots & \ldots & \ldots & \ldots & 18\end{array}$

The Trade before the Advent of the Railway

The Early Railway Period, 1902-1921

The Period of Railway Expansion, 1922-1931

The Phase of Recovery and Adjustment, 1932-1939

The War Period, 1939-1945

III. The Dhow Trade of Lake Victoria : Its Rise and Decline

Origins and Organization of the Dhow Trade

The Challenge of the Dhows

The Victory over the Dhows

The Dhows in Eclipse

IV. The Trade of Lake Victoria at the Present Day .

General Considerations

The Sugar Trade

The Maize Trade

The Coffee Trade

The Rice Trade

The Timber Trade

The Millets Trade

The Cotton Trade

The Cotton-Seed Trade

The Ghee Trade

The Groundnut Trade

The Oil Seeds, Beans, and Tobacco Trades

The Fishing Industry

The Trade in Imported Goods

Conclusion

Select Bibliography 


\section{LIST OF TABLES}

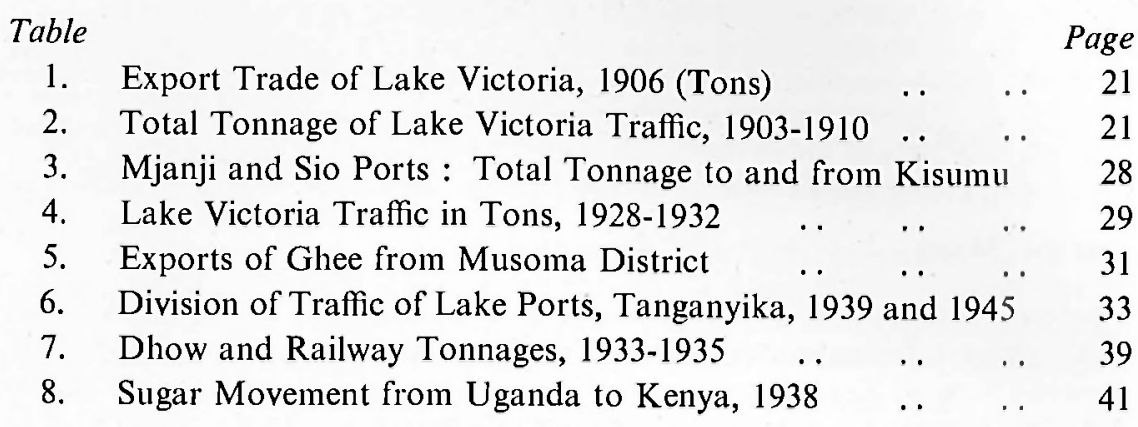

Plate

\section{LIST OF ILLUSTRATIONS}

1. Fishing Karua, Asembo Bay, Central Nyanza

Facing Page

Frontispiece

2. Loading Sugar at Port Bell, Uganda, January $1949 \quad$.. 10

3. Dry Dock, East African Railways and Harbours, Kisumu .. 10

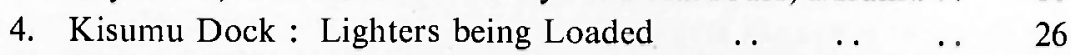

5. The Steam Tug Buganda and Train of Lighters leaving $\begin{array}{lllllllll}\text { Mwanza } & . & \text {. } & \text {. } & \text {. } & \text {. } & \text {. } & \text {. } & 26\end{array}$

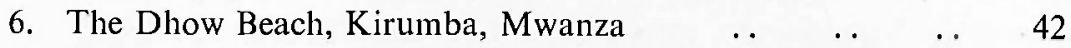

7. Fishing Canoes, Asembo Bay, Central Nyanza $\quad$. $\quad$.. 42

\section{MAPS}

in pocket at end

1. Place Names

2. Lake Victoria Total Traffic 1913-1914

3. Lake Victoria Total Traffic 1919-1920

4. Lake Victoria Total Traffic 1926

5. Lake Victoria Total Traffic 1932

6. Lake Victoria Total Traffic 1938

7. Lake Victoria Total Traffic 1944

8. Lake Victoria Dhow Traffic 1938 and 1951

9. Lake Victoria Total Traffic 1952

10. Lake Victoria Commodity Traffic 1952 : Sugar, Maize, Coffee, Rice

11. Lake Victoria Commodity Traffic 1952: Timber, Millets, Cotton, Cotton-Seed 


\section{CH A P T E R I}

\section{THE GEOGRAPHICAL SETTING OF LAKE VICTORIA}

\section{Size and Position}

Lake Victoria occupies a shallow depression on the East African Plateau, stretching from $0^{\circ} 20^{\prime} \mathrm{N}$. of the Equator to $3^{\circ} \mathrm{S}$., and from $31^{\circ} 41^{\prime} \mathrm{E}$. to $34^{\circ} 52^{\prime} \mathrm{E}$. The height of the lake above sea-level is 3,720 feet, and its maximum depth is little more than 270 feet. The lake is roughly square in shape, its eastern shores being prolonged eastwards both in the north by the Kavirondo Gulf and in the south by the Speke Gulf. In area the lake is 26,828 square miles, approximately the same area as that of Scotland. Its greatest length in a north to south direction is about 250 miles and from west to east its greatest breadth is roughly 200 miles. The coastline is well in excess of 2,000 miles in length.

\section{Relief and Drainage of the Lake Plateau}

Lake Victoria rests centrally on that portion of the East African Plateau which lies between the eastern and western branches of the Rift Valley system. This major relief feature is here called the Lake Plateau. Except to the north, where the land falls away to the swamp basin of Lake Kioga and the valley of the Nile, the land rises away from the lake. To the east the highlands of the Mau in Kenya rise to over 9,000 feet, extending southwards into Tanganyika in highlands between 6,000 and 8,000 feet in height. The fall of ground westwards to the lake is gentle and the highland changes gradually into a region of low plain broken here and there by residual hills of crystalline character. To the south-east this plain merges into the vast dry plains of the Serengeti. To the north and north-west the Mau passes into the broad fertile plateau of the Uasin Gishu at a height between 6,000 and 8,000 feet and dominated to the north-west by the great volcanic mass of Mount Elgon.

To the south of Lake Victoria, breached by Smith Sound, is a belt of low hill country, much of it consisting of granite intrusions about 4,000 to 5,000 feet above sea-level. This country serves as a divide between the lake area and the vast level surface which is so marked a feature of the plateau of Western and Central Tanganyika.

To the west of the lake the land rises to culminate at a distance varying from 150 to 200 miles in the highlands which overlook the Western Rift Valley. In Uganda there are large areas of low-lying country fringing the lake, particularly in the lower valleys of the Katonga and Kagera rivers. Westwards the great level erosion surface, between 4,000 and 5,000 feet, which is so well developed in Ankole and on the flat tops of the Buganda hills, replaces the lake shore lowlands. This erosion surface rises westwards to over 6,000 feet in the mountainous area of kigezi in the south-west of Uganda and to much greater heights in the uplifted mass of Ruwenzori which overlooks the valleys of Lakes Albert andEdward. In the south-west of the lake, steep cliffs mark its junction with the parallel ridge and valley country of Bukoba. The Bukoba area stretches inland at a height of 4,000 to 5,000 feet for fifty miles, merging into the higher country in the west of Karagwe and Ruanda-Urundi, a continuation southwards of the Kigezi country. 
The lake occupies a shallow depression resulting from a probable downwarping of the plateau, with uplift of the highlands marginal to the east and the west, at the time of the formation of the rift valleys. The lake, which in the past has fluctuated considerably in area, merely represents the gathering ground of water in the lowest portion of the plateau. Its northeastern extension, the Kavirondo Gulf, is thought by some to have been initiated by faults, a well-marked scarp bounding it to the north, and a less pronounced one to the south. ${ }^{1}$ The drainage pattern of the Lake Plateau suggests that prior to the formation of Lake Victoria the rivers of this portion of East Africa flowed westwards to the Congo system. Warping of the plateau has affected the drainage to the north and west of the lake, producing a profound difference in character between the rivers entering the lake in the east and those on the west.

To the east and north-east of Lake Victoria the rivers maintain a course similar to that of the pre-lake period, and the rivers flowing through well cut valleys are deep, broad and at times swift in character. Such rivers are the Sio, the Nzoia and the Yala which enter the lake north of the Kavirondo Gulf, the Nyando and the Sondo which enter the gulf south of Kisumu, the Gori reaching the lake in Karungu Bay, the Mara with its wide estuary at Musoma and the Suguti to the south of Musoma. All these rivers rise in the highlands to the east and the majority maintain their flow throughout the year.

To the south of Lake Victoria the drier conditions and the proximity of the watershed to the lake have resulted in few rivers, all short, and the majority maintaining their flow only during the wet season.

To the north and particularly to the north-west, the rivers are very different in character. The downward tilting of the plateau to the east has reversed the rivers and brought about drowning of the valleys, the majority of which are today long swamps choked with papyrus. Lake Kioga and the valley of the River Katonga are examples of this type of drainage. Some of the rivers, particularly those of the Lake Kioga system, have re-established their original flow westwards, others such as the Katonga and the Kagera have portions of their course draining eastwards to Lake Victoria and portions draining westwards to the Western Rift Valley. East of Kampala the streams draining northwards to the Lake Kioga system rise in some cases within a mile of the shore of Lake Victoria. Of the western rivers flowing into Lake Victoria, the Kagera alone is an open flowing river. The Kagera, rising in the highlands of Karagwe and Ruanda-Urundi, has in its upper course developed a drainage system which is strongly adjusted to the tilted structure of the Karagwe-Ankolean sediments, which strike roughly north-south across country. In its lower course the Kagera is wide and has entrenched its bed. The stream is exceedingly swift and the meandering of the river makes it a most difficult one to navigate. A sand bar across its mouth is a further obstacle to navigation, and a broad belt of papyrus and thick forest fringing its banks impedes the vision of the officers navigating the tugs which use the river as far west as Nyakanyasi. The Katonga contrasts markedly with the Kagera. The former river is nothing more than a great choked papyrus drain, and only in the wet season when the river rises across the swamp road is it possible to obserye any flow of water.

\section{The Coastline and the Islands of Lake Victoria}

The drowning of the river valleys in the north-west has resulted in a number of long gulfs and channels, e.g., Murchison Bay and Salisbury Channel, which penetrate the lake shore area and lie between the islands

I. R. M. Shackleton, "A Contribution to the Geology of the Kavirondo Rift Valley", Quarterly Journal of the Geological Society, Vol. 106, 1950, p. 345. 
and the mainland. The island groups, such as those of the Sese Islands and those of the Buvuma group, are essentially those higher portions of the plateau which have not been submerged with the formation of the lake. Many of them rise with steeply cut cliffs from the lake and are crowned with hills which resemble those of the Buganda mainland. Ukerewe Island, the largest island in Lake Victoria, is separated from the mainland by a very narrow strait which is crossed by a causeway. Ukara Island has, like its neighbour Ukerewe Island, a series of rocky hills and granite outcrops in the centre. To the south-west, the islands of Luwondo and Maisome which lie across the Emin Pasha Gulf are, like Kome Island South, upstanding portions of the submerged plateau. The long line of the Bumbireh Islands which stretches from north to south along the Bukoba coast is a detached portion of the ridge and valley country which characterises the coastal area of Bukoba District. Submergence too, is the cause of the long ria-like opening of Smith Sound and Mwanza Gulf. This prolongation of the lake southwards for nearly forty miles cuts through low granite hill country which rises around it on all sides, granite rocks, such as the Bismarck rocks at Mwanza, rising here and there from the waters of the Gulf.

The character of the lake coastline is very varied. Along the Bukoba coast the high ridges of the Bukoba Sandstone make a steep cliff-bound coast, the cliffs rising 200-300 feet above lake level. North of the Kagera River the character of the coast changes to low swampy country floored with lake alluvium. This is a zone of papyrus swamp, of lagoons, e.g. Lake Nabugabo, and of forest, e.g. the Tero Forest to the immediate north of the mouth of the Kagera. With the exception of the sheltered bays of the southern portion of the Emin Pasha Gulf and the more sheltered channels of the Buganda area, the whole west coast of Lake Victoria is exposed to the full force of the dominant south-east winds and papyrus along the actual lake fringe is rare. The muddy bottom of the lake is in many places replaced by sand, and the bays, e.g. Bukoba Bay, have open sandy beaches. Further round the coast the northern shores of the lake are approached by the hill country of Mengo District and the southern part of Busoga District. Here the coastline varies between swampy forest-covered flats and flat topped hills with steep sides separating the swampy valleys and rising up to 500 feet above lake level. Passing to the north-east, the incidence of papyrus increases and the low flat clay plains which edge the Kavirondo Gulf and form the broad triangular plain of Uyoma on the north side of the mouth of the Kavirondo Gulf are all deeply fringed with papyrus. In South Nyanza the coast of the open lake is dominated by the mountains of Usengere and Gemba, which rise steeply 3,000 feet above the lake level, and which contrive, with the hilly islands of Rusinga and Mfangamu, to conceal the southern approach to the narrow opening of the Kavirondo Gulf. From Ukerewe Island to Karungu the eastern coast of the lake is fringed by reedy bays, which give way inland to low country rising gradually eastwards. On this stretch of the coast many of the bays are fringed with "black cotton " clay soils, or by lake sands, some of which penetrate far inland, e.g. the lowland area of Mugango, fifteen miles south of Musoma and north of the Suguti River. Character is given to the east coast by the frequent hill masses of granite, schist and gneiss, which, rising above the general level of the coastal area, form hilly peninsulas and make headlands to the bays. These continued inland as hill ridges serve to separate the river valleys, e.g. the peninsulas of Jkerewe and Majita which flank respectively the southern and the northern shores of the Baumann Gulf. To the south-east of the lake the great embayment of the Speke Gulf forms a stretch of sheltered shallow water with reed-fringed shores and a muddy bottom. At its western end, both to the north and south. the Gulf is bordered by crystalline hill country, but at its head in the east, it passes into the great clay plains of Ushasi, Nata and Ikoma, an area largely thorn bush and infested by tsetse-fly, which may have been formerly under the waters of the 
lake. The southern coast of the lake west of the Mwanza Gulf is backed by broken hill country, much of it granitic and covered with bush. The coastline, rocky and difficult of access, is sheltered and the waters of the area are a considerable source of fish.

\section{The Climates of the Lands Marginal to Lake Victoria}

The portion of the Lake Plateau with which this account is concerned is not marked by great regional variations in temperature. The whole zone, lying within equatorial latitudes has mean annual temperatures which lie between $70^{\circ} \mathrm{F}$. and $75^{\circ} \mathrm{F}$. Temperatures show a tendency to rise to over $80^{\circ} \mathrm{F}$. with distance from the lake, particularly to the south and south-east over the drier plains. Lower temperatures are found in the highland country, as for instance, in the hill country of Kisii in Southern Nyanza where mean annual values varying between $60^{\circ} \mathrm{F}$. and $65^{\circ} \mathrm{F}$. are to be found. Though the range between the coldest and warmest months shows little seasonal variation, the range being in the order of $3^{\circ} \mathrm{F}$. or $4^{\circ} \mathrm{F}$., there is considerable diurnal variation. At Entebbe the annual mean minimum temperature is $63.3^{\circ} \mathrm{F}$. and the annual mean maximum temperature is $78.6^{\circ} \mathrm{F}$, making a mean daily range for the year of $15.3^{\circ} \mathrm{F}$. At Ukiriguru, 15 miles due south of Mwanza, the annual mean minimum temperature is $58^{\circ} \mathrm{F}$. and the annual mean maximum temperature is $88^{\circ} \mathrm{F}$, giving a mean daily range for the year of $30^{\circ} \mathrm{F}$. The cool nights are offset by the long hours during the day when temperatures remain steady at $70^{\circ} \mathrm{F}$. or above. But differences in temperature, though they may produce minor changes in the plant assemblages of the various vegetation regions of the lake basin, are not the prime controls in the distribution of vegetation belts around the lake or of the agricultural activities.

Unquestionably rainfall is the climatic control of over-riding importance. Its amount and its seasonal distribution influence to a marked degree the economy of the various regions around Lake Victoria. The seasonal distribution of the rainfall varies from locality to locality, and occurs with the passage over the area concerned of the inter-tropical convergence zone. ${ }^{1}$ The inter-tropical convergence zone is that in which the south-east monsoon and the north and north-east air currents meet. The air current from the south-east is often moist and unstable, whilst that from the north and northeast, coming from the desert areas, is dry and more stable. Lake Victoria and the swamps of Uganda provide a large water surface from which occurs considerable evaporation, some four to five millimetres a day. ${ }^{2}$ The presence of these water bodies gives rise to unstable conditions in the air masses which blow over them, and a convectional element in the rainfall is attributable to this fact.

In the northern half of the lake region the rain falls throughout the year with only a slight seasonal variation. From the middle of December to the middle of March the area falls under the dry stable north-east winds and drier conditions are experienced, although occasional thunderstorms break the drought and no month is completely dry in this period. From the middle of March to the middle of May is a period of heavy rainfall, a period known generally as the "long rains". This is followed from June to September by a dry period which is far less pronounced than that of the period December to March. Rain occurs frequently, resulting from unstable conditions in the south-east air current which is then dominant. A second period of heavier rainfall follows in October and November. This second rainfall maximum,

1. J. P. Henderson. Some Aspects of Climate in Uganda with special reference to Rainfall, 1949, Vol. II, No. 5 ,

2. Ibid. p. 7 . 
known as the "little rains", is not so well marked as the "long rains" and at times fails to occur. This rainfall regime which is prevalent over the northern part of the lake can be summarised as one in which rain comes throughout the year, but in which two peaks of rainfall occur soon after the equinoxes.

In the southern lake area, and more especially those parts of Tanganyika which fringe the lake on the east and south-east, the rainfall is more seasonal in its occurrence. The rain begins in late October or early November and continues until May. At times there is a tendency to drier conditions in January and February. The heaviest falls are in March. A dry season, which is pronounced, occurs from June to August, the period when the south-east winds are at their maximum. In this southern region the rainfall tends to be concentrated into one long period from late October to May, followed by a single dry season in the middle of the year. In this southern belt the reliability of the rainfall is less certain than that to the north, and failure of the rains occurs from time to time, as for instance in the year 1949, which was disastrously dry.

The marked differences in the rainfall amounts received by the various regions of the lake basin can be attributed to the predominant easterly component in both the southern and northern air masses. From Bukoba District to the Nyanza Province of Kenya, the western and northern coasts have heavy rainfall, varying from 50 inches a few miles inland to over 80 inches in the island groups, such as the Sese Islands. In the north-western parts, violent thunderstorms in the night and the early morning are frequently responsible for such rainfall, whilst to the south-west in the Bukoba District a great proportion of the rain comes in the morning.

The mean annual rainfall decreases inland from the west coast of the lake, the approximate rate of fall being of the order of one inch per mile. A dry belt extending southwards from western Busoga through most of Buganda into Ankole, western Bukoba and Biharamulo Districts succeeds the wet lake fringe. Here the rainfall is about 40 inches a year, heavier amounts falling on the higher hill country which forms the boundary between the Belgian Congo and British territory. From a rainfall point of view the highland area of Kisii and North Mara which lies across the Kenya-Tanganyika border can be included in the western and northern region of the lake. This east coast area has heavy rainfall, much of it orographical in character.

In the south and south-east of the lake area rainfall conditions are very different. In this area there is a tendency for the marginal lands of the lake to take on some of the rainfall characteristics of the dry semi-arid plains which stretch away to the south-east and south in Central Tanganyika. The rainfall is low, only exceeding 40 inches in the islands of Ukerewe and Ukara, whilst to the east of the Speke Gulf the rainfall is little above 30 inches a year.

\section{The Vegetation Divisions of the Lake Basin}

\section{8}

Lake Victoria and its marginal lands can be divided by a line running from the Emin Pasha Gulf in the south-west to Karungu Bay in the northeast. To the north and west of this line rainfall is irpexcess of 45 inches along the coast and is relatively reliable. To the south and east of this line rainfall, with few exceptions, is below 45 inches and is subject to considerable fluctuations. This fact is reflected in the agricultural practices which distinguish the northern and western coast belt from the southern and eastern belt, and in the distribution of vegetation. 
The area to the north and west of the line receives the full benefit of the rainfall derived from the great expanse of lake. In Bukoba the dry sandstone ridges with their poor soils support a poor short grass vegetation and the swampy valleys between the ridges have a thick jungle of thorn bushes, palms and papyrus. This unusual vegetation is a reflection of the soil conditions of the zone, for on the patches of better soil which occur, it is common to find trees, such as Maesopsis eminii and Markhamia platycalyx, which are typical of the trees further to the north. Northwards the Bukoba zone merges into the lower valley of the Kagera River and from here stretching northwards, the coastal fringe of the lake has a natural vegetation succession which comprises thick rain forest in the low swampy valleys passing through tall grass on the hill flanks to forest again on the hill tops. These forests, e.g., the Tero Forest on the north bank of the mouth of the Kagera River and the Mabira Forest on the left bank of the Nile between Kampala and Jinja, are some of the principal timber regions of Uganda and Western Tanganyika. The swamps are choked with papyrus and along their fringes the two palms, Phoenix reclinata and Raphia buttorum, are very common. Inland this coastal fringe merges into a region which occupies most of the southern portion of the Districts of Northern Nyanza in Kenya, Mbale, Busoga and Mengo in Uganda, together with the eastern portion of Masaka. This belt is one of tall elephant grass country, Penmisetum purpureum, growing between 6 to 10 feet in height in those places where it is undisturbed. Characteristic of this belt of tall grass savannah are the valuable "mvule" trees, Chlorophora excelsa, and the stately " mwafu" trees, Conarium schweinfurthii. In this belt the swamps, which occupy much of the valley area in Uganda, are a mass of papyrus, sedge and water lilies, and their edges are fringed with the aforementioned palms. West of this belt of tall savannah the belt of low rainfall, which as described runs through northern Buganda and most of Ankole, results in a short grass savannah area covered with considerable amounts of acacia thorn bush. It serves to separate the elephant grass area of the western region of Bunyoro and Mubende from its counterpart in the east.

The character of the vegetation to the south and east of the lake is markedly different. West of Mwanza Gulf and east of the Emin Pasha Gulf the vegetation is mainly that of the " miombo "type, the dominant vegetation association being that of Brachystegia-Isoberlimia woodland. To the south and east of this region is the great "cultivation steppe" of Sukumaland and Nyamwezi, an area supporting a dense population of people and animals. It is largely devoid of surface water and of vegetation other than very short cropped grass and planted clumps of Cassia siamea. The "cultivation steppe" is separated from the southern shore of the Speke Gulf by a belt of granitic hill country. Little natural vegetation remains, except on the hill tops, where a mixture of cacti and euphorbias is common. Near Mwanza coconut palms planted by man give an exotic touch to the vegetation. This coastal fringe to the southern shore of the Speke Gulf merges north-eastwards into very arid thorn bush country to the east of the Speke Gulf. The drier condition of the eastern side of Lake Victoria is evident from the vegetation of the Musoma section of the coast. Associations of xerophytic plants such as euphorbia, prickly pear, aloes and sisal cover the small granite hills which are a feature of this strip of coast. Inland, acacia thorn bush becomes dominant, though short grass between the trees is very suitable for grazing. Much of the bush in this district is tsetse-fly infested.

The low shore flats of the Kavirondo Gult are drier than the hilly country immediately to the north or south and the vegetation has much in common with that of the Musoma coast fringe. To the south of the Gulf the dry fringe gives way inland to the wetter woodland and grass country of the Kisii hills, and to the north the rolling country of North Nyanza gradually assumes the vegetation character of the western side of the lake. 


\section{Limits of the "Lake Victoria" Zone}

A consideration of the trade of Lake Victoria leads to a consideration of the limits of the hinterlands of the lake ports. In a broad sense they might be defined as including all those areas which habitually use the lake as part of their system of communication with other areas and for which the lake provides the most convenient means of pursuing trade. If such a definition is accepted, the question of alternative means of tapping areas adjacent to the lake must be carefully taken into account. The construction of railways to and around the lake has had a very important control upon the volume and the flow of lake traffic, and the economic boundaries of the lake must not be considered as static. When the only rail outlet from the lake was Kisumu, Lake Victoria can be considered to have included within its economic boundaries "in extenso", the whole of Uganda, much of the Nyanza Province of Kenya, and the whole of the Lake Province of Tanganyika. The construction of a railway line from Tabora to Mwanza in 1928 not only divorced from the lake's economic sphere most of the trade of the important agricultural area of Sukumaland, but created, in addition, a traffic divide between Mwanza and Kisumu, a divide which varies in position from time to time and from commodity to commodity. The construction of the Uganda extension of the railway which reached Kampala in 1931, and the construction of the branch lines from Tororo to Soroti, and Kisumu to Butere, for many purposes narrowly restricted the northern boundary of Lake Victoria's economic sphere of influence. Traffic passing southwards from Uganda to Tanganyika and vice versa is unaffected by these railway developments, but much of the traffic of Eastern Uganda and of Northern Nyanza now by-passes the lake on its way to and from the Kenya coast. It is no longer possible to assess the economic development of Uganda by a study of its lake traffic alone, nor is it really possible to assess the areas from which the lake traffic is derived, as much of the traffic flow from Port Bell to Kisumu results from purely arbitrary diversions of traffic by the authorities from the railway to the alternative lake route.

With these limitations in mind an attempt may be made roughly to outline those marginal areas of Lake Victoria whose trade is represented to a greater or lesser degree in the traffic of the lake. In the west, south of the River Kagera, a line drawn parallel to the coast at a distance of thirtyfive miles includes most of the productive areas of Bukoba and Biharamulo Districts. North of the Kagera the zone widens to include those portions of south-east Ankole which are tapped by the main road running from Bukakata to the Belgian Congo. In a broad sense, all that area of Uganda lying between the Katonga and Kagera Rivers falls within the sphere of Bukakata, but the bulk of the traffic comes from the eastern portion of the Masaka District. In Mengo District an arbitrary line running forty miles inland from the lake shore to the Nile will enclose an area which is typical of the country from which the major portion of the present lake traffic of Uganda is derived. It includes roughly the "elephant grass" zone of Buganda. A network of roads converges upon Kampala, and commodities brought by lorries to the town, there reach railhead. Goods destined for Kenya are then allocated on purely economic or administrative grounds either to rail or lake traffic. Extension of the radway line from Kampala westwards to Mityana, without doubt, will affect the traffic of the port of Bukakata and to a lesser extent that of Port Bell. In the above circumstances the proportion of lake traffic derived from far afield in Uganda will vary from time to time as the density of traffic on the railway dictates. Since it is somewhat fruitless to attempt to delimit the section of Uganda north and east of Kampala which falls regularly within the economic sphere of Lake Victoria, it is perhaps better to denote an area representative of that from which most of the traffic is likely to come. East of the Nile, in Busoga, much 
of the lake shore lies in a closed sleeping sickness area, now forming a belt of forest. Both the railway and the settlement swing away from the lake east of Jinja. Very little lake traffic comes from the Busoga area except sugar which is grown and manufactured a few miles to the north-east of Jinja. From Jinja a line drawn parallel to the lake shore at a distance of approximately twenty-five miles and continued to Kisumu will include most of those parts of the Districts of Busoga, Mbale and Northern and Central Nyanza which can be said to have an outlook to the lake. This narrow restriction is due to prohibited settlement on much of the coast of Busoga and to the alternative routes supplied by the Jinja-Nairobi and the Kisumu-Butere railway lines.

Kisumu, and to a lesser degree, Mwanza, being outlets for the lake and served by single railway lines, have hinterlands which though varying from commodity to commodity, can be said to extend to the coast of the Indian Ocean. Only a fraction of the traffic of Kisumu is derived from the area immediately to the east, though considerable quantities of goods of an East African and foreign origin pass through the port from Nairobi which functions as a distributing centre, or come direct to Kisumu which also has a large distribution trade.

South of Kisumu a line joining the south-eastern corner of the Kavirondo Gulf, i.e., the mouth of the Nyando River, to the north-western corner of the Speke Gulf, delimits an area roughly thirty miles in width between it and the lake, in which economic development has resulted in some measurable form of trade. Finally the line runs at a distance of some thirty to forty miles parallel to the southern shore of Speke Gulf and the eastern side of Smith Sound and Mwanza Gulf. It here includes the coastal belt which directly focuses upon the port of Mwanza, and also a portion of that part of the Sukuma steppe which, though tapped by the railway linking the area to the south and away from the lake, contributes a portion of its products to lake traffic. West of the Mwanza Gulf a narrow belt of perhaps fifteen miles along the coast, and cut off by bush to the south, finds its main outlet through the lake services.

Within these limits so defined there are a number of regions which can be differentiated, and the remainder of this chapter is devoted to a description of the more important of them.

\section{The Bukoba Region}

In the south-west, the Bukoba region is unique among the regions around Lake Victoria. It comprises a long strip of country, some 70 miles in length from north to south and about 30 miles wide from east to west. It is divided longitudinally by long parallel ridges and valleys, the latter swampy and draining northwards to Lake Ikimba and the River Kagera. The region rises by steep sandstone cliffs several hundreds of feet above lake level, and presents the appearance of rolling flat-topped ridge country. The Bukoba Sandstone, a fine-grained compact rock, interbedded with shales and penetrated by thick sills of dolerite, is the dominant rock in the region. Earlier peneplanation levelled the area and scattered a mantle of loose rock material over the surface. ${ }^{1}$ Rejuvenation of the area by uplift has caused the streams to dissect the zone into ridges, whilst tilting of the area has checked the later flow of the rivers and produced swampy conditions in the valleys.

The soils which have developed are strongly controlled by the lithology of the area. The sandstone has yielded a thin covering of almost pure sand, poor in bases. In those areas where the shale and dolerite occur, soils of a better quality, fine sandy clays, have been produced. Transport of soil has 1. An excellent account of the Bukoba area is to be found in the essay by G. Milne, "Essays in Applied
Pedology, III Bukoba ". East African Agricultural Journal, Vol. IV, 1938. 
brought about mixing and at irregular intervals patches of better soils. These areas of better soil are limited and most of the Bukoba region is covered with exceptionally poor soils. The heavy rainfall of the region, which averages 75 inches a year, together with the high temperatures averaging $68^{\circ} \mathrm{F}$., ensures rapid decomposition of humus and the heavy leaching of soluble soil components. The presence of hard "murram" pans and flatlying flaggy shale beds ensures that nowhere is there a shortage of water.

The patches of better soil rigidly control the settlement pattern. Trial and error has revealed that the poorer soils are incapable of being continuously cropped. Their use as areas for pasturing cattle and goats and for the collection of firewood has resulted in their metamorphosis from forest into open common-land, covered with thin, wiry and exceptionally poor grass. Patches are tilled about once in eight or nine years for a quick catch crop such as groundnuts.

In striking contrast, the settled areas present a picture of intense fertility. These areas may vary from small pockets of a few hundred acres to long strips of several miles, usually found on or just below the crests of the ridges. The fertility of these soils has been built up through generations of careful husbandry. The basic crop of the area is the banana, a deep rooting plant which freely circulates the mineral water of the soil. Constant mulching of the ground with banana leaves and the addition of refuse, wood-ash and cattle manure has built up the initial fertility of the soil. The cattle, housed at night in the houses of the people and partly stall-fed there, are fed on the stems of the banana and weeds carried to them. Intercropping of the ground with legumes and small annuals such as onions, tomatoes, pumpkins and beans, etc., ensures a system of polyculture.

The Haya, who are the tribe inhabiting the district, occupy permanent heritable holdings, and each fertile plot is carefully handed on from generation to generation. These fertile plots are less than one-fifth of the area of the Bukoba District, and upon them a dense population of 301,665 people (1948 census) is mainly crowded. In some areas the population is over 400 per square mile and it averages about 180 over the whole district.

In the banana gardens is grown the considerable quantity of robusta coffee which forms the principal export of the area and provides the Haya with an income well above subsistence level. The mulching of the ground with banana leaves forms an essential part of the system under which the coffee is cultivated. Coffee has been cultivated in the Bukoba area for many generations, but production on a large scale began with the German administration in the early years of the century, and has developed until today the crop exported varies between 6,000 and 8,000 tons a year. Picking and hulling of the crop has not in the past been very well performed, and the quality of the crop has suffered. The formation of the Bukoba Native Coffee Board, to organise the industry by controlling the quality of the coffee and its marketing, was achieved in 1947. The industry is now established on a co-operative basis.

Bukoba town is a small settlement sited on a sand flat at the foot of cliffs, which here swing back from the coast to form a large, exposed, crescent-shaped bay. The port consists of a pier sheltered by a breakwater, and the approach to the pier is particularly exposed to onshore winds.

\section{The Basin of the Middle and Lower Kagera River}

To the north of the Bukoba region the land falls away to the basin of the River Kagera. In the lower portion of the basin, lake deposits of recent origin are to be found, continuing northwards as a narrow fringe to the lake as far as Masaka. Much of the area is covered with the remnants of thick forest which in former times must have covered much larger areas of 
Uganda. The soils are often grey sticky clays or grey sandy loams. The houses are rather of the modern Ganda pattern, the square mud huts only occasionally being replaced by the typical cone-shaped grass hut of the Haya. The Kagera is used for extracting the timber from the region, though some of it goes by road to Bukoba.

Westwards the Kagera emerges from the hill country of Ankole. In this region the rocks are the shales and quartzites of the Karagwe-Ankolean system, overlying the metamorphic crystalline Basement Complex which dominates the Buganda region to the north-east. Folding of the KaragweAnkolean beds was accompanied by intrusion of granites. Later erosion of the overlying sedimentary beds has exposed the granitic cores, forming what has been termed " arena " country. The granite centre is surrounded by a ring of scarps fluted in form and having the appearance of downland country. The granite intrusions are responsible for the presence in the region of minerals, particularly tin ore. Mining occurs on both sides of the Uganda-Tanganyika border west of Nyakanyasi, the port on the Kagera which serves the mines.

Ankole lies in the dry belt of low rainfall, 30-40 inches, and is not well endowed with surface water. The vegetation is principally short grass studded with thorn bush and euphorbia. Much of the area is infested with tsetse-fly. The drier parts of Ankole are cattle country grazed by the herds of the Hima. The outlet for such crops as are marketed is through the port of Bukakata.

\section{The Southern Buganda and Busoga Region}

Stretching northwards from the forests fringing the north bank of the lower Kagera River is a region bordering the lake which occupies eastern Masaka District. Beyond the Katonga River this region is continued eastwards into the southern parts of Mengo and Busoga Districts. In that portion which lies within the Province of Buganda there are large areas floored by the crystalline Basement Complex. Consisting of gneisses, schists and quartzites, this series of very ancient rocks has also been intruded by igneous material, mainly granite. An erosion level which bevels the hills is here to be found between 4,200 and 4,500 feet, and lower erosion levels occur at 4,000 feet and at the present lake level. Thick "blankets " of ironstone or laterite have been developed upon these levels. The ironstone occurs in thick sheets around much of the shores of Lake Victoria, and since it tends to hold the water, its presence has a controlling nature upon the occurrence of springs. When it is found close to the surface good wells are easily constructed. Tilting of the region has checked the flow of water in the broad valleys which lie between the steep-sided hills and only where drains have been cut through the thick papyrus swamps is any water movement usually visible. East of the Nile, granites later than the Karagwe-Ankolean rocks in age are dominant. Here the country is more open and rolling in character than in Buganda. To the north the country falls in height to the levels of the Lake Kioga basin and swamps are larger and more extensive.

Weathering of the soils under the high temperature and rainfall conditions which characterise this region proceeds to a very great depth, and the mantle of soil usually covers a very thick loyer of rotted parent rock. The soils form a series or " chain " which commonly can be traced from the hill-tops to the swamp valleys. This catenary eharacter of the soils is a frequent feature of the regions around the lake. In Buganda and Busoga the catena is somewhat as follows : murram on the hill-tops, succeeded by a zone of red earths on the hill flanks. The red earths are usually deep and when first cultivated have a good texture and supply of organic material, but after a few years of cultivation their structure breaks down and soil 


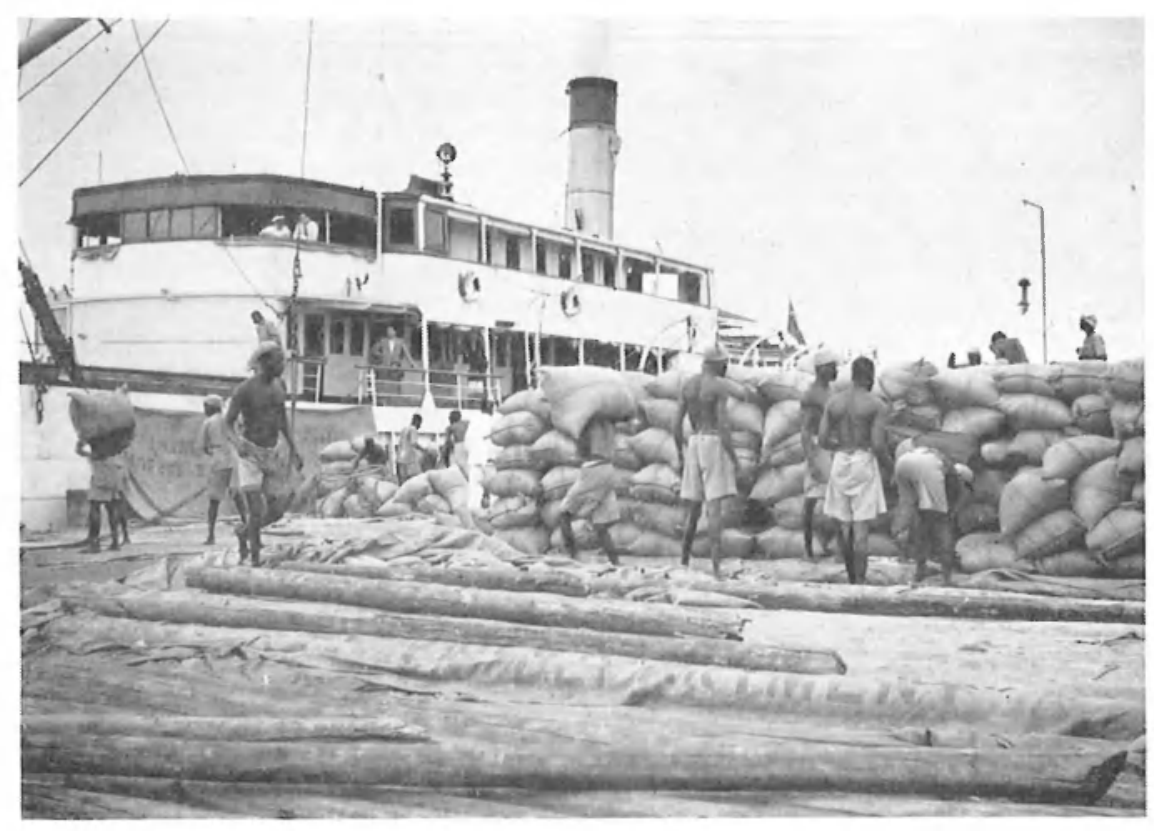

2 Loading sugar at Port Bell, January 1949. This consignment packed in bags of $2200 \mathrm{lbs}$, was all shipped to Tanganyika. The boat is the S.S. Usoga, a cargopassenger boat, which like its sister ship the S.S. Rusinga, sails round the lake once a week, calling at Port Bell, Bukakata, Bukoba, Mwanza and Musoma and resting at Kisumu for two days.

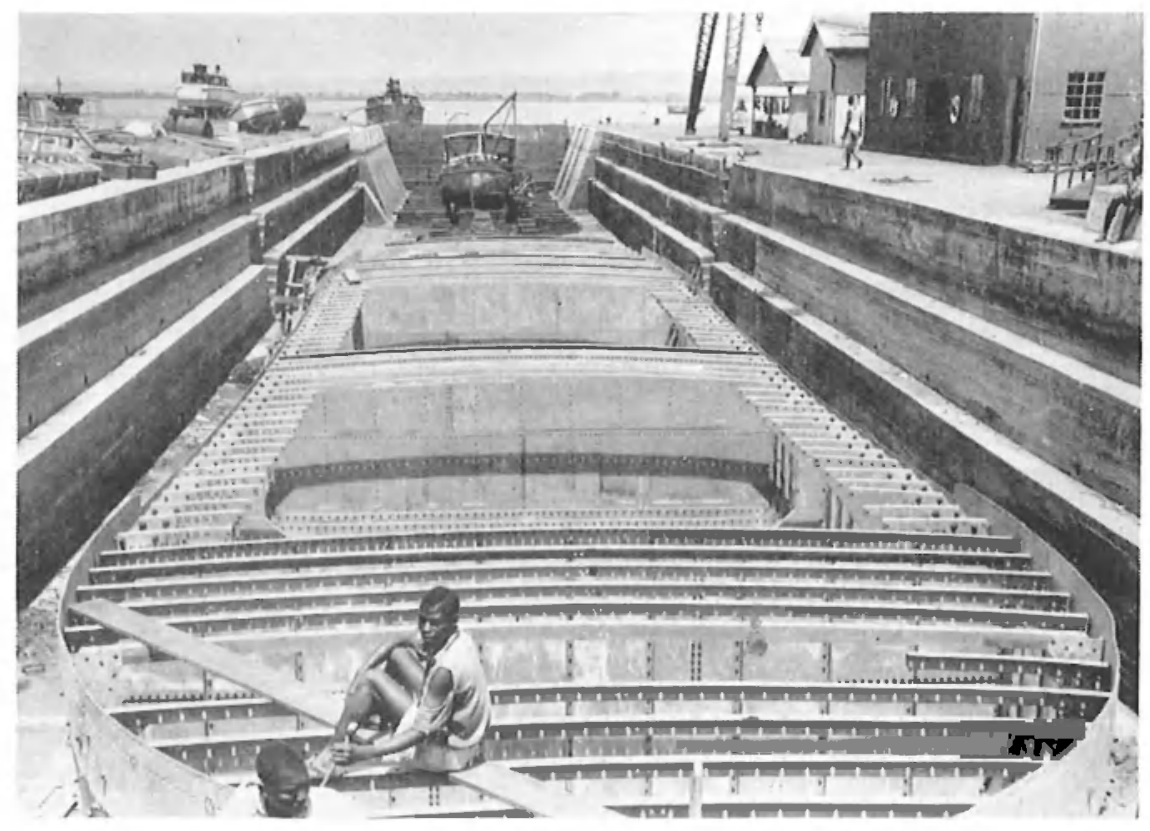

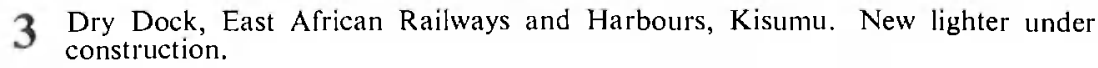


erosion begins. The soils grade in colour from grey on the highest part of the hillslope through chocolate-brown soils to deep red at their lowest point. Further down the hillside the red earths pass into dark sandy soils which border the swamp fringes and grade off into the lowest of the swamp soils. The swamp soils comprise sticky blue clays overlain by a dark sandy soil which contains a great deal of organic material. Around the shores of Lake Kioga in the north of Busoga the two lowest members of the catena are widespread. The true swamp soils, thick sticky clays, are very unsuitable for cultivation, but the swamp fringe soils are often sandy to great depths and produce good crops in years of fair rainfall.

Within this region the zone nearest to the lake tends to have a thick forest cover. In Busoga the withdrawal of the population from the lake fringe, because of the presence of sleeping sickness, has allowed much land formerly cultivated, to revert to forest, and at this point the shore belt of forest broadens. Inland the area has a rich cover of tall grasses, elephant grass being dominant. Large trees are found usually in single stands, often growing close to the individual houses or springing up at the base of old termite mounds. Uncultivated land is quickly covered by a secondary growth of bushes, woody shrubs such as the purple flowering Acanthus, young saplings and tall grass.

Settlement within the region consists of small individual holdings on which are built the square mud and wattle houses of the Ganda and the Soga. The settlement is dispersed; the only nucleated settlements are the groups of small Indian-owned shops, which are to be found at the road junctions. There is a tendency for the people to avoid settling the hilltops, where usually a thick mantle of murrain is to be found. The houses are sited principally on the red earth soils of the hill flanks, but pressure on the land results in settlement extending down to the swamps.

The staple food of the people is the banana, and the permanent banana garden surrounds the house. Coffee plots too are permanent. The rest of the holding is divided into land resting, and land under cultivation of annual crops. The introduction of cotton as a commercial crop has led, in the last 40 years, to an increased cultivation of land. An increasing population has resulted in far less land being available today for shifting cultivation. Consequently, much land is cultivated for too long a period, and in some areas, particularly close to Kampala, soil erosion is a serious problem. The land is cleared in the dry period of January and February, after the cotton crop is harvested, new land being burnt over. Food crops of beans and groundnuts are sown with the March rains, and are followed in May and June by the cotton sowing. Further sowings of cotton, as late as September in the south of Mengo District, take place when the beans are cleared. The cotton harvest begins about the middle of December, and from then until late January, the population is busy picking the bolls and carrying them to the ginneries. The average size of a cotton plot is about three-quarters of an acre.

Government control of cotton growing is enforced, restrictions being placed on the seed used and the marketing of the lint. The cotton ginning industry was formerly run almost entirely by Indians, who also form the principal trading element in the population. Today a number of ginneries are owned and worked by African co-operative societies.

Indians own the largest areas of alienated land which are under plantation cultivation. There are two such large areas given up to the cultivation of sugar cane. The first sugar factory was opened ind 924 at Kawolo, between Jinja and Kampala, and the second in 1929 at Kakira, nine miles north-east of Jinja. Both these areas are close to the lake shore. Here, on an average, temperatures stay above $70^{\circ} \mathrm{F}$., the critical temperature for sugar cane, for periods of at least 14 hours a day. The seasonally well distributed rainfall ensures even growth of the cane and steady output. Labour both in the 
fields and in the factories is largely immigrant; the Ruanda and the people of West Nile District, with their respective homelands well beyond what is usually considered as the sphere of influence of Lake Victoria, form the core of the labour supply. The factories are quite large plants and are run on power obtained chiefly by burning the crushed cane trash. These two sugar factories both lie along the Kampala-Nairobi railway line and they provide sugar not only for Uganda, but are the chief sources of sugar for much of Kenya and of Western Tanganyika.

Other alienated areas within this region are usually under tea or coffee cultivation, and are found within a 40-mile radius of Kampala or in the Masaka area. Tea is consumed mainly within the Protectorate, the habit of tea drinking amongst the Africans providing a ready sale for all tea produced. Plantation coffee is small and the bulk of the coffee export of this region is of the "robusta" variety grown on the small plots of the Africans. Cultivation is general throughout the districts of Mengo and Masaka, with a tendency for heavier production in the latter area. The marketing of the coffee, its grading, hulling and export, are all controlled by government ordinance and rigorous standards are applied.

Within this area are three major centres of population, Masaka, Kampala and Jinja. Masaka, the administrative centre for the Masaka District, lies approximately half-way between Kampala and Mbarara, the chief town centre of Ankole. Masaka forms a convenient centre for the population of the district, the major portion of the people being found in the east. It is linked by road to Bukoba and to the lake port of Bukakata, 20 miles to the east. Bukakata is merely a pier with a station staff and the produce passing through Bukakata is processed in the Masaka neighbourhood. Bukakata is difficult to approach at low water, but the raising of the lake level by the Nile dam at Jinja will increase the depth.

Kampala, the chief commercial town in Uganda, is connected by a radial system of roads to all portions of the Protectorate and is about seven miles from its lake outlet, Port Bell. Formerly the terminus of the long, tortuous railway line which connects Uganda to Kenya, Kampala is now linked by railway to Mityana in the west. The town is expanding at a very rapid rate and has most of the features associated with modern towns. The considerable Indian population, which as elsewhere, forms the trading element, gives the town something of an Indian character. Light industries, such as the processing of tobacco, are scattered in and around the town, and much further development of these industries is likely to take place as the needs of the urban population grow.

Jinja, the third town, is expanding rapidly and is the headquarters of the Eastern Province administration. In the near future it will become an industrial centre, as here the Nile is dammed and hydro-electric power is available in quantities sufficient for industrial purposes. At present Jinja lies between the two sugar factories and has a tobacco packing factory. The Kampala-Jinja-Tororo-Kenya trunk road has been largely straightened, macadamised, and converted into a modern arterial road. This road carries very heavy lorry traffic, particularly in the cotton ginning season, and it is expected to be of major importance in the industrial development of Jinja and of the Protectorate.

\section{The Nyanza Region}

One of the long arms of Lake Kioga, the River Mpologoma, serves as the boundary between the region of Buganda and Busoga and the area to the east. Around the River Sio the land is flat and forms a low plain but rises away from it to give place to rolling upland country which is dissected by numerous perennial streams. Here, bounded on the east by the Nandi 
Escarpment, by the lake in the south, and tapering northwards to the high plateau country east of Mount Elgon, is an area which is a northern subdivision of what can be called the "Nyanza Region". The region comprises much of the administrative districts in Kenya of North and Central Nyanza. Like that of the Uganda region to the west it has a well distributed rainfall. There is the same division of the year into the "long rains " and the "short rains". Inland towards Kakamega the total fall is about 75 inches a year and the interval between the long and heavier rains and the short rains is very short. Nearer the lake shore and the lower ground, rainfall decreases and the months of December to February are much drier than inland. The soils are of great inherent fertility, but pressure of population on the land, resulting in the continuous cropping of the ground and the cultivation of slopes that ought not to be cultivated, is threatening the area with serious consequences. The area is very densely populated, the density ranging from 120 to 250 per square mile in every location and in the locations of Bunyore and Maragoli in North Nyanza reaching a figure of 766 per square mile. ${ }^{1}$ The tribes comprise the Bantu Luhya, mainly to be found in North Nyanza, and the Nilotic Luo people to the south.

The Luhya are principally cultivators. Their huts of the traditional circular pattern are grouped in family units. Around the huts are the banana patches and the vegetable patches of the wives. The arable fields or plots adjoin the homestead, whilst cattle are grazed on communal grazing grounds. Crops grown are principally cereals, finger millet (eleusine), sorghum, maize and rice, the latter in the swamp areas. There is a tendency towards maize monoculture because of the money which its sale brings, and a dangerous inclination to try to obtain two crops a year, with the consequent impoverishment of the soil.

The Luo areas to the south differ in the greater number of cattle per head of population and the greater interest of the people in cattle keeping and fishing rather than in agriculture. On the flats fringing the lake, groundnuts bulk largely in the crops grown. Cotton, formerly a cash crop, has suffered eclipse in recent years because of the quicker and easier returns to be had from maize and rice crops. The shallow, muddy Kavirondo Gulf was, until overfished, a very rich fishing ground. Today many of the Luo men are to be found in fishing camps far south along the eastern shore of Lake Victoria, engaged in catching and importing fish, crudely dried, into the densely populated area to the north of the Kavirondo Gulf.

The area is served by two railways : to the north the Kenya-Uganda line which crosses the Uasin Gishu Plateau, and to the south-east the KisumuButere line which runs north-westwards from Kisumu for approximately 40 miles. It is the area to the west of this second line which today provides the traffic for the small ports between the Uganda border and Kisumu, though fish landed at these ports penetrates far inland by the network of secondary roads and by the use of native buses for transport.

The principal town of the region is Kisumu which is not only the administrative centre for the Nyanza Province of Kenya, but is also the chief port on Lake Victoria. Founded at the beginning of the century as the terminus of the railway, it was a small thriving town until the extension of the railway line to Uganda was completed in 1931. By diverting much of Kisumu's traffic, this extension led to a period of decline which was only partly offset by the rush in the "middle thirties" to the "gold area of Kakamega. Recovery from the depression and war-time expansion of trade has led to considerable development of the town. Today it is a thriving industrial, commercial and administrative centre of a prosperous and thickly populated Province.

It is situated at the north-east corner of the Kavirondo Gulf, on a ridge

1. N. Humphrey, The Liguru and the Land (Nairobi : Government Printer, 1947), pp. 2-9. 
which slopes steeply to the dock area and to the east falls away to the very flat clay Kano Plains, drained by the River Nyando. The town is laid out on a rectangular pattern. The lake shore is occupied by the extensive docks, repair sheds, storage sheds, oil installations and railway facilities which are the raison d'etre of the town. Running parallel to this zone is a long road of factories abutting on to the railway line. The industries reflect many aspects of the lake trade. There are mills engaged in milling maize, hulling rice, and crushing groundnuts and simsim for their oil, factories curing hides and skins, ice factories producing ice for fish packing, timber yards and engineering works, some specializing in the supply of mining materials. From this road the trading section of the town stretches up the hill, the main street consisting of modern shops, whilst the side streets conform to the pattern of the typical East African Indian bazaar of small corrugated-iron roofed shops. Kisumu, as a commercial centre of importance, has a large distributing trade with all parts of the Lake Victoria region. On the crest of the ridge is the residential area, both Indian and European, and away from the town to the north is the African location.

Behind Kisumu are the Kano Plains, dry and dusty in the dry season and swampy and intractable in the wet season. Along the Kisumu-Nairobi railway line between Kibos and Muhoroni is a plantation sugar area owned by small Indian cultivators. ${ }^{1}$ The sugar factory is at Miwani about halfway between Kibos and Muhoroni. The bulk of the Miwani sugar is sent eastwards and the produce of this area does not enter into lake trade to any great extent. Much "jaggery", unrefined sugar, is produced by the small growers.

To the south of the Kavirondo Gulf is the isolated but important area of South Nyanza which forms the southern sub-division of the "Nyanza Region". The lake shore area consists of heavy black clay soils which are stiff to cultivate. Ploughing is common and the area is a heavy producer of groundnuts ; cotton production, as elsewhere in the Luo areas, has suffered a decline. In the Luo areas cattle are numerous and ghee ${ }^{2}$ is an important product of the area. Inland towards Kisii the land rises into rolling, well dissected and well watered hill country, between 5,000 and 6,000 feet above sea-level. Of late years the Kisii people have become very heavy producers of maize. Very large quantities of maize and other grains find their way out of the area by lorries to the piers which comprise the ports of Homa Bay and Kendu Bay on the Kavirondo Gulf.

The highland area of Kisii is continued over the frontier into the district of North Mara in Tanganyika. Here in the highlands the fertile red volcanic soils varying from light loams to clay loams are intensively cultivated. A heavy cattle population has led to much ploughing of the area because of the availability of oxen for ploughing. Since the land varies in height between 4,700 and 6,000 feet above sea-level, the rainfall is good, averaging in a year between 55 and 65 inches.

The people, who belong to the Kuria Federation of Chiefdoms, are mixed farmers, but the cultivation of maize is rapidly increasing in area. Maize began to be grown first in about 1936 as a food for the labour employed in the mines of the Musoma area, but it has to compete with cheap Kenya maize imported through the lake ports. The main grain crop of the people is eleusine, and sweet potatoes are the chief root crop. Cattle and cattle products-ghee and hides-are the main source of cash, with maize second in importance. The area, which is the granary for the Musoma District, is capable of great development, with careful control, as a mixed farming area.

1. Kibos is five niles and Muloroni thirty miles east of Kisumu.

2. Ghee is a form of clarified butter. 


\section{The Musoma Region}

Between the highland area of North Mara and the lake shore are two zones which, though part of the Musoma Region, are separated from it by the Mara River. They comprise a coastal belt and a belt of country lying north of the Mara River between the highlands to the east and the coastal belt to the west. The coastal area forms the Girango Federation of Chiefdoms and has a low variable rainfall, amounts fluctuating between 27 and 35 inches a year. The soils are either light sands or the black cotton clay soil. The bulk of the people are Luo who have penetrated peacefully from South Nyanza. Though cattle-owning people, they are, as further north, keen users of the plough. The area is a famine area, and is at times fed by food from the highland area. Cattle provide the chief source of cash, though the people migrate as labourers. The middle belt has a rainfall of about 40 inches and is a thickly populated area, with a high stock density. The soils vary from light sandy loams, derived from granite and characteristic of the hillsides, to thick black clays in the valleys. Eleusine and sorghum are the chief food crops, but ghee production is the chief source of cash.

South of the Mara River, the Musoma region falls into three types of country. In general the district slopes gently westwards to the lake, with an average fall of 1,500 feet from east to west. The first type of country is along the shore. Here the ground has gentle and medium slopes which are broken by granite kopjes. The soils are very light sands derived from the granites and are easily eroded. Along the river valleys clays occur. The area has light rainfall like the coastal area of North Mara and the natural vegetation is xerophytic; small bushes of acacia and occasional small deciduous trees are interspersed with colonies of aloes, sanservia and euphorbia intermixed with tall coarse grass. The lake area has a heavy population, the presence of fish and water being a great attraction. This is particularly true of the heavily eroded peninsula of Majita to the immediate north of the Baumann Gulf. Rice is cultivated along the shores of the lake, and in Majita forms the chief cash crop of the people. Further to the north of Majita, cotton is an important cash crop, and at Mugango, 15 miles south of Musoma, a ginnery serves this northern extension of the cotton area of the Lake Province of Tanganyika. The light soils are reflected in the secondary importance of eleusine and sorghum, bulrush millet forming the chief food crop of the people, together with the cultivation of large quantities of cassava and sweet potatoes in the wet sandy soils close to the lake.

The second type of country is the hill belt which occupies the central area of the district, stretching eastwards from about 10 miles inland. This area is composed principally of the eight chiefdoms of the Zanaki Federation. The hills are irregular masses, usually with slopes of a medium nature rising about 500 to 600 feet above the general level of the country, individual peaks rising another 500 feet above the general level of the hills. Many of them are granitic and it is in this area that gold reefs, such as those of Buhembe mine, 25 miles east of Musoma, are being worked. The area because of its greater elevation has more rain than the coastal belt, the mean annual rainfall increasing to a figure between 35 and 40 inches. The soils, though only of medium quality, comprise a range from light loams to heavy clays and are more resistant to erosion than those of the coastal belt. The area has a well-wooded cover of small deciduous broad-leaved trees and grass is good. The Zanaki, an industrious, wealthy cattle people who are also good cultivators, are spread evenly over the region, whichis not overpopulated. The food crop is eleusine but ground nuts form the chief cash crop. Cotton is not popular.

The third type of area in the Musoma region comprises the great clay plains made of black heavy clays commonly known as "mbuga" soils. These areas, if they have a good rainfall and the clay is leavened with an 
admixture of loam and sand, are highly fertile and good crops can be grown, as for instance, cotton in the Guta area of Usashi. Others, such as the plains of Bwassi found along the south bank of the Mara 20 miles east of Musoma, are good groundnut areas or cattle country, much of the ghee from Musoma District coming from this region and its neighbour to the east, Ngruimi. In the drier areas the "mbuga" soils are famine areas much covered with acacia thorn bush, rich in game but fly-infested, e.g. the Nata and Ikoma Plains.

\section{The Mwanza Region}

The final region of economic importance in the Lake Victoria zone is that which fringes the southern coast of the lake for a distance inland of approximately 30 to 40 miles. East of the Mwanza Gulf and Smith Sound the Mwanza-Tabora railway line diverts much of the traffic of Mwanza and Kwimba Districts away from the lake. Before the opening of the line in 1928 , the influence of the lake on trade extended much further south than it does today. In describing the region south of the lake it is necessary to mention the character of the "cultivation steppe" of Sukumaland which lies behind the coastal belt in the south-east. Although the steppe is part of a great natural region which stretches south of the lake for over a hundred miles, the bulk of it divorced from any physical or economic contact with Lake Victoria, yet undoubtedly there is a proportion of lake traffic which is derived from this area. It would be difficult in the present state of knowledge to delimit any fixed traffic divide, though the bulk of the traffic which actually comes from the area is most likely to derive from the part within fifty miles of the lake.

The coastal belt falls within the Districts of Mwanza and Kwimba and comprises broken rocky granite tor country. There is a distinct gradation of soils from the granite outcrops to the valley floors. The hilltop is covered with patches of scrub and the soils are thin dark grey loams. On the upper hill slopes brownish-red loams follow which merge on the lower hill slopes into grey sands on a murrain subsoil. The valley floors are covered with black heavy clay, which has calcareous concretions at depth. In this area the rainfall, which is about 30 inches a year, is concentrated between the months of November and June. The hill slopes with their lighter soils are cultivated for the main food crops, bulrush millet and cassava, sorghums being grown on the heavier soils in the valleys. The chief cash crops are cotton and rice. The growing of cotton is encouraged by the Government as part of the economic effort of the Province ; the distribution of seed and the cultivation and marketing of the cotton are all controlled by the Government. Ginning is in the hands of the Indians, the ginning season lasting from July to late September. Rice is grown in small basins which hold up storm water. The rice, germinated in seed beds, is planted out by hand in the small basins after the ground has been well dug and puddled. The yields of rice areas dependent on storms for their water are apt to fluctuate a great deal from year to year. Better yields come from the rice areas which are fed by water seepage from the hill slopes or from the lake itself. The many small settlements along the Speke Gulf and along the lake shore west of the Mwanza Gulf are served by tugs and lighters and motor launches of the East African Railways and Harbours system, and by dhows.

Ukerewe Island may be considered as lying within this coastal belt. In area it is 110 square miles and it has a population which in density exceeds 250 per square mile. The well-distributed and heavy rainfall has led to heavy cultivation both of food and cash crops. Lack of grazing and the presence of East Coast Fever prevent large numbers of stock being kept. The island has a serious soil erosion problem, which is aggravated by the eagerness of 
the Kerewe to grow cotton. There is an essential need for a balanced system of cropping and maintenance of soil fertility. On the small island of Ukara the dense population has evolved a very admirable and elaborate system of crop rotation, but only when the soil has been all but completely ruined. There is very urgent need in Ukerewe to adopt a similar system before the land reaches exhaustion point. Fishing is a great source of wealth to the people and fish is a major item in their diet.

Behind the southern coastal belt of Lake Victoria is one of the most interesting areas in East Africa. Stretching all the way from Mwanza to Tabora is a region so gently undulating that much of it appears quite flat. In this area of poor to moderate rainfall, 28 to 35 inches per annum, water is only obtained from springs and holes in the sandy river beds. The rivers are seasonal and for much of the year are dry. Into this area, the "cultivation steppe" of Sukumaland and Nyamwezi, is packed a dense human population and a great concentration of stock. Land pressure is acute and it is difficult to rest land from cultivation or from grazing. Schemes are on foot to re-settle the people in the bush areas to the west by first providing them with large earth tanks and small valley-dams to create a water supply; and the cattle are to follow the people after the bush has been cleared and the tsetse-fly driven out. The people are industrious cultivators and the area produces valuable crops of cotton and rice. The willingness of the people to sell their cattle has made this region a most valuable source of meat for areas such as Bukoba, where cattle are relatively few and the income of the people high enough to allow meat to figure in their diet. Luo cattle traders from as far afield as South Nyanza also find their way into Sukumaland to buy cattle for the Luo who are very great meat eaters.

Mwanza, which is the chief centre of trade in the southern part of the lake, is second in importance to Kisumu as an outlet from the lake. The town makes a striking contrast with Kisumu, for despite its connection by rail to the coast at Dar-es-Salaam, it is clear that development has not been great. Situated on sandy flats on the east side of the Mwanza Gulf and hemmed in by granite tors, the town is hot, dusty and not very healthy. The pier, though served by a railway siding, is small and the dock area has none of the installations which characterise that of Kisumu. Although there is a big Indian bazaar, there is a marked absence of commercial offices and factories, other than a few small rice mills and cotton ginneries.

In presenting a broad picture of some of the regions which especially influence the trade of Lake Victoria, it must be emphasised that it is not these regions alone which contribute to the trade of the lake. Accurate delimitations of the economic influence of the lake would require an estimate of the hinterland of at least each major port. This would involve a calculation of the hinterlands as they varied from commodity to commodity. In the absence of statistical information on the origin of traffic for each port, it is clearly impossible to determine with accuracy the hinterland of Lake Victoria, and a broad survey of the regions most likely to supply the traffic has therefore been presented in its place. 


\section{CHAPTER II}

\section{THE HISTORICAL GEOGRAPHY OF THE TRADE OF LAKE VICTORIA}

\section{The Trade before the Advent of the Railway}

The discovery in 1858 by Speke of the great lake which he called Victoria Nyanza confirmed the existence of one of Africa's greatest natural features, which had long been suspected by the geographers. Of the unhappy controversy which raged over this discovery, nothing need be said here, except to mention that the argument was finally settled by the circumnavigation of the lake in 1875 by H. M. Stanley, It is to Stanley that we owe our first knowledge of the trade of the lake, or rather of its lack of trade. Stanley, in a remarkable passage, forecast vividly the trade which in large measure has come to pass. He recognised the unifying influence that the lake should have upon its marginal lands and their peoples, but he made it abundantly clear that intercourse between one part of the lake and another was nonexistent 80 years ago, largely as a result of "the murderous hate with which man beholds man in the beautiful lands around Lake Victoria". "For the period of the next 20 years most of our information is derived from missionary sources, and they provide us with only casual references to trade. Apart from the missionaries, the only outside influence of any importance was that of the Arab slave traders. The main slave routes lay to the south of the lake basin, with the chief centre at Tabora. But there was one important zone of Arab influence within the lake basin-the country of Buganda, the area which had also attracted the early missionaries.

The trade carried on by the Arab and half-caste merchants from Zanzibar consisted mainly in the barter of guns, ammunition, cloth and beads in exchange for ivory and slaves. ${ }^{2}$ The chief centre for the ivory was SouthWest Uddu (now Buddu), ${ }^{3}$ though other ivory was obtained by trade with Lango and Busoga. The route of this trade was southwards, the slaves, captives taken in the wars of Mutesa, King of Buganda, and his chiefs against neighbouring tribes, and the ivory being taken to Zanzibar via Unyanyembe (Tabora). The long journey was shortened by a voyage across the lake by canoe to Kagei on the southern shore of the lake a few miles north of the present Mwanza. ${ }^{4}$ In 1882, Rubaga (a suburb of Kampala), formed the most northerly depot for this traffic. ${ }^{5}$. From there, in batches perhaps as many as 200 at a time, the slaves were transported by canoes provided by Mutesa, to Kagei, whence they reached the main slave depot at Unyanyembe. We are told on the authority of the then chief of Kagei that the size of this traffic was annually about 1,000 slaves.

As time went on other traders appeared, notably the ex-missionary Stokes 6 who, turning to trading in ivory, brought up in 1889 a boat in sections from the coast, and assembled it on the lake. It is a sign of the growing trade with Buganda that we read of the appearance in 1882 of an Arab dhow. ${ }^{7}$ This reference, the earliest I have traeed, is important in view of the claims put forward by the Indian dhow owners of Mwanza in 1939, that the dhow trade of Lake Victoria was of considerable antiquity. Even after 1890 ,

I. H. M. Stanley, Through the Dark Continent, 1878, Vol. I, p. 223.

2. C. T. Wilson and R. W. Felkin, Uganda and the Egyprian Sudan, 1882, Vol. I, p. 189

4. Wilson and Felkin, op. cir. p. 189.

5. Ibid.

6. R. P. Ashe, Chronicles of Uganda, 1894, p. 124

R. P. Ashe, Two Kings of Uganda, 1890, 2nd edition, p. 43 
however, dhows were supplemented by canoes. In fact it would appear from Ashe that there was perhaps only one dhow, belonging to an Arab, Said bin Saif.

After 1890 events moved rapidly. Prior to this date all contact from the coast with the Buganda Kingdom had been from the south. The northern route had been closed, as it not only entailed the difficult journey across the Masai steppe, but also those who followed it came up against the Ganda tradition which forbade entry into the country through Busoga. Bishop Hannington, in ignorance of this tradition, lost his life in the first attempt to approach Buganda by this route. European penetration into East Africa was developing and in 1895 the old firm of Boustead and Ridley were the first to launch a steamer on the lake. ${ }^{1}$ In that year a 32-feet steam launch Kenia No. 1 was launched, having been carried by porters from the coast to Nassa, but it was wrecked in the process of launching. The following year, 1896, the experiment was repeated successfully, the steam launch Kenia No. 2 being put into commission. ${ }^{2}$ This was followed the next year by the similar building and launching of the 36-feet steam launch Ruvenzori which as late as 1933 was still in commission, being used in connection with the fishing trade at Kisumu. The authorisation of the construction of the Uganda Railway had been given in July 1895, and by 1899 the railway had reached Kikuyu. In that year a steam launch of 65 feet driven by a water tube boiler was taken by rail to Kikuyu and then carried in sections to Kisumu by porters, where it was assembled and launched. This boat, the Kampala, registered at Lloyds as 35 tons was, after a chequered career, bought by the Uganda Railway and ran as the tug Huseni until 1937.

The construction of the Uganda Railway had as its objective the suppression of the slave trade by bringing law and order into the interior of Africa. It is interesting to note that it was considered that the only chance the railway had of becoming remunerative, was in civilizing the dense population of the Lake Victoria basin. It followed naturally then that early consideration should be given to the placing of steamers upon the lake and of a port at the terminus of the railway. The Imperial British East Africa Company had earlier contracted for a 500-ton steamer, the William Mackinnon, to be carried in sections to the lake and launched. The sections of this boat were abandoned between the coast and the lake, and it was several years before the parts were re-collected and assembled at Kisumu, the boat having in the meanwhile been purchased by the Uganda Government. It was launched in 1900 by the District Commissioner at Kisumu, C. W. Hobley, and for many years provided a passage between Port Florence (the old name for Kisumu) and Entebbe. It was joined three years later by the Winifred, a 700 -ton vessel capable of nine knots, and in 1904, by the Sybil, a sister ship to the Winifred. These last two boats were capable of carrying 150 tons of cargo and 20 passengers, and with their launching a new era begins in the development of the Lake Victoria basin.

\section{The Early Railway Period, 1902-1921}

The completion of the railway line from Mombasa to Port Florence enabled goods traffic to begin on January 15th, 1902 , and passenger traffic on March 1st of that year. A special down rate of one penny per ton-mile was instituted for all classes of goods other than ammunition, firearms, ivory and spirits, the intention being in particular to Toster agricultural development within the two territories.

1. P. H. Clarke and C. W. Hobley, First Steamers and Molor Cars in Kenya, East Africa, March 2nd, 1932, 2. . 590 . Letter and comments.

3. C. G. Whitehouse, "The Building of the Kenya and Uganda Railway", Uganda Jomnal, Vol. 12, 1948 p. 14. 
During the period of railway construction a complete survey of the whole coastline of the British half of Lake Victoria was made, and the outline of the Kavirondo Gulf elucidated. Port Florence was chosen to be the terminus of the line in preference to the original choice of Port Victoria nearer the Uganda border. ${ }^{1}$ An early map of Kisumu ${ }^{2}$ published by the Admiralty in 1902 shows quite clearly the disadvantage which is common to many of the lake ports - the extreme shallowness of the water. The approach to Kisumu is shown as being on an average nine feet in depth with several shoals of mud with only five to six feet clearance.

At very much the same period that British influence was extending over Uganda and Kenya, German penetration into Tanganyika was progressing, and German settlement sprang up around the southern shores of Lake Victoria. Emin Pasha had founded Bukoba and laid the foundations of today's coffee industry of that area. ${ }^{3}$ These early German settlements at first relied upon their supplies coming from Tabora by porters to Mwanza where they were shipped by their own dhows on the lake. Even in Kampala German traders were so well able to obtain supplies in this way that British traders could not compete."

The opening of the Uganda Railway altered this. At first, traffic on the new railway was nearly all 'up country', less than five per cent. of the traffic flow being seawards. This naturally reflected the opening up of a new colony, the emphasis being on imports needed for the development of the territory, exports of necessity being small because of the general lack of development. It was realised that this was only a temporary phase and as early as 1901 we find Sir Guildford Molesworth prophesying that :

"With the completion of the railway, the whole lake coastline of

800-1,000 miles with the adjoining fertile and populous districts will be opened up by water communications to rail traffic. And as the Uganda Railway will be first to tap the lake, the trade of these districts will naturally gravitate into this channel, which will become the established trade route."5

The truth of that last remark was not perhaps realised in 1901, but it is the first indication of a problem that by 1928 was to become of major importance in the relations between the two railways of Tanganyika and Kenya and Uganda.

Development of the lake zone was rapid, particularly in Uganda and in the German area to the south and south-west of the lake. In Uganda the external trade of the Protectorate increased in value from a total of $£ 94,717$ in $1902-03$ to $£ 314,385$ in $1905-06$, imports increasing from $£ 62,538$ in 1902-03 to $£ 108,204$ in 1905-06. ${ }^{6}$ Expansion in traffic was mainly in the import of goods such as provisions, spirits, tobacco, building materials, machinery, cotton goods, apparel, hardware, paper, cement, and in exports of chillies, coffee, hides and groundnuts. Trade began to develop with adjacent territories and in 1905-06 ivory and rubber " in transit" from the Congo passed through Uganda to the value of $£ 4,619$ and $£ 7,610$ respectively. ${ }^{7}$

The ports in those early days were eight in number, Kisumu, Jinja, Munyonyo (the fore-runner of Port Bell), Entebbe, Bukoba, Mwanza, Shirati and Karungu. In 1906 the total export trade of the lake was 5,482 tons, which showed a remarkable increase over 1905, for which the total

1. C. G. Whitehouse, "The Building of the Kenya and Uganda Railway ", Uganda Journal, Vol.12, 1948, p. 5. 3. T. S. Jervis. "A History of Robusta Coffee in Bukoba "' Tanganyika Notes and Records, December 1939.

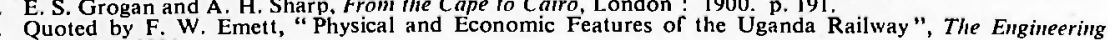
Magazime, 1901 .

Colomial Anmual Report, No. 525, 1905-06, Cmd. 3285-12. The figures for 1905-06 show a favourable balance of trade. a feature which has consistently characterised the foreign trade of the Uganda Protectorate.

7. lbid. 
was 2,603 tons. It is perhaps of interest to note the regional distribution and the content of the early export trade as outlined in the table below :-

TABLE 1

EXPORT TRADE OF LAKE VICTORIA, 1906 (tons) ${ }^{1}$

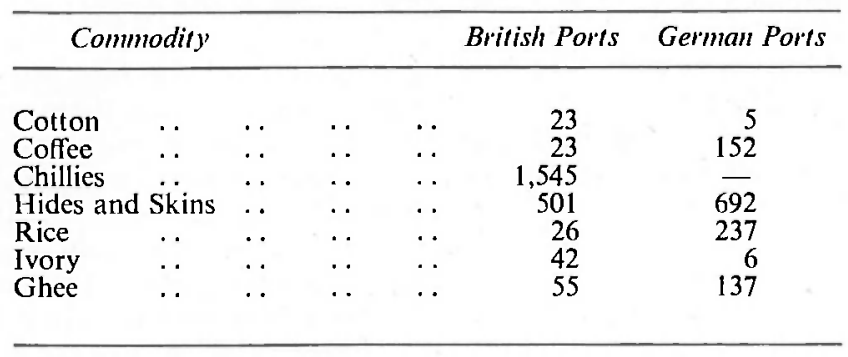

Note the relative proportions at that time of the various commodities and their distribution. Cotton production then was in its infancy, and the British traffic was largely made up of chillies grown extensively in Busoga and exported from Jinja. One notes the early importance of Bukoba coffee, Mwanza rice, and the surprising export of hides and skins from Bukoba of 692 tons. Today very few cattle are to be found in Bukoba District and the area imports cattle from Sukumaland for consumption.

It is in 1906 that we have the first indications that trade was developing faster than the facilities of the lake services." At Mwanza goods lay for months waiting transport, despite the fact that the Uganda Government leased the Sir William Mackinnon to the railway. Port facilities were, however, improved by the completion in that year of the Kisumu dock, and piers at Entebbe, Mwanza and Jinja. Imports during 1906 were 5,481 tons, principally of manufactured goods and building materials. Entebbe was the largest importing port for British territory, with a total of 2,077 tons, much of this probably being material for the construction of Entebbe.

The years of 1907-10 were years of marked expansion and must have filled the early supporters of the railway with very high hopes. Despite consecutive years of poor rainfall which seriously affected the crops of groundnuts and chillies, the appearance of the new crop, cotton, which was unaffected by the droughts, enabled total tonnages carried, as expressed in the figures of the Uganda Railway, to show a steady rise as the following table shows :-

TABLE 2

TOTAL TONNAGE OF LAKE VICTORIA TRAFFIC, 1903-1910 3

\begin{tabular}{|c|c|c|c|c|c|c|c|c|}
\hline & & $1903-4$ & $04-5$ & $05-6$ & $06-7$ & $07-8$ & $08-9$ & $09-10$ \\
\hline From the Coast .. & . & 1,374 & 3,919 & 5,481 & 6,782 & 7,129 & 9,440 & 8,830 \\
\hline To the Coast $\ldots$ & . & 745 & 2,603 & 5,485 & 7,646 & 6,968 & 8,853 & 9,888 \\
\hline TOTAL & . & 2,119 & 6,522 & 10,966 & 14,428 & 14,097 & 18,293 & 18,718 \\
\hline
\end{tabular}

The next four years, 1910-1914, reflect through the figures of lake traffic the amazingly rapid development of Uganda and the opening up of the wealthy Kavirondo area. By 1910 cotton production in Uganda had assumed

1. Anmual Report of the General Manager of the Uganda Railway 1905-06.

2. Ibid.

Anmual Report of the General Manager of the Uganta Railway 1909-10. 
what was for the economic conditions of the time a phenomenal size, and the rapidly developing area around Masaka necessitated the creation of the new port of Bukakata, ${ }^{1}$ destined to have at the present day the largest traffic of any port other than Kisumu and Mwanza.

The same year, 1910, saw the opening of two new ports on the Kavirondo Gulf-Asembo Bay and Homa Bay. In the first five years after the arrival of the railway at Port Florence, 1902-1907, there would appear to have been little development within the Kavirondo Province (renamed Nyanza Province in 1947). It is true that Karungu was one of the first ports, but its trade was little more than that involved by the presence there of the first administrative centre of South Kavirondo. In the early days the naked tribesmen of the Kavirondo area confined their requirements to iron and brass wire, beads and cowrie shells for ornamental use, and ostrich feathers and buffalo hides for ceremonial purposes. Clothing was not used and the sale of cotton goods was small, though blankets were popular. The completion of the railway saw much of the Indian labour turning to trading activities, and small Indian shops sprang up even in the remotest parts of the Kavirondo Province. But the trade of these small Indian shops consisted primarily in the sale of cheap ornaments, all of which had to be conveyed within the district by porterage or ox-cart transport.

The great drought of 1907 was, however, the turning point. ${ }^{2}$ Hitherto, the staple food of the Luo had been red mtama, little of which was marketed, the bulk being consumed by the grower, ivory, hides and skins being the only products exported from the area. The drought caused a famine in Kisumu and necessitated the importation into the area of maize and beans, thus beginning the cultivation of those crops in Kavirondo. The following year white sim-sim was introduced, the seed coming from Jinja, and later yellow sim-sim from China. So rapidly did trade develop that the position changed from one of no exports in 1908 to one of 28,000 tons being moved downrail from the zone in $1912 .{ }^{3}$ To tap the densely populated hinterland of North Kavirondo, occupied by the Luhya, Sio was established as a port in 1910 , and was followed in 1912 by the opening of the complementary port of Mjanji.

This rapid increase of trade continued to tax the transport services to the utmost. Despite the addition of the Clement Hill (1,100 tons) in 1906 and the Nyanza (1,146 tons) in 1907 to the lake flotilla, old German files of 1913 complain about the inadequacy of the service and bring forward proposals for the construction of a branch to Mwanza from the German railway at Tabora. In October 1913, the German Consul at Mombasa addressed a letter to the Governor of German East Africa pointing out that the Uganda Marine would have great difficulty in coping with greater freights, and that if a German railway were to be constructed to tap the lake, the Uganda Marine would withdraw their freight service from the German part of the lake. To some extent though, the German authorities were to blame for the congestion, as they were not co-operative in improving port facilities. Bukoba was particularly handicapped by its poor harbour, though a breakwater was begun in 1912 .

By 1912 Uganda-grown cotton was playing the dominant role in the trade of the Protectorate which it has done over since. The Busoga Railway from Jinja to Namasagali was completed and opened on January 1st, 1912, opening up a new field for cotton growing in the Lake Kioga area, and this was further enhanced by the establishment dering that year of the first cotton experimental station, at Kadunguru in Teso. The same year saw an expansion in cotton ginneries in Uganda. Hitherto, apart from a small ginnery

1. Anmual Report of the General Manager of the Uganda Railway 1909-10.

3. Anural Report of the General Manager of the Uganda Railway 1912-13.

4. Sessional Paper No. 4. 1933, p. 7, Sec. vii. Legislative Council, Tanganyika Territory. 
which operated at Entebbe, the only ginneries available had been the Uganda Company's ginnery at Kampala-a power driven ginnery erected in 1906 - and the British East Africa Corporation's ginnery at Kisumu. This entailed, as cotton growing expanded, considerable head porterage of seed-cotton between Jinja and Munyonyo, and Jinja and Entebbe. The lack of communication between Kampala and its port, other than a monorail operated by the Uganda Company, and ox-cart transport, further complicated the position. ${ }^{1}$ In 1912 a cotton ginnery was opened at Jinja and others were set up in the Lake Kioga area. By 1914-15 the number of cotton ginneries in the Protectorate had expanded to twenty. These new ventures are clearly reflected in the drop of tonnages imported from intermediate ports by Kampala and Entebbe, imports to Entebbe falling from 3,166 tons in $1911-12$ to 1,524 tons in the following year.

Between 1905-06 and 1911-12 there occurred a change in relative values of exported goods from Uganda. In the first year the value of exported cotton was $£ 1,089$ - a trivial sum compared with the value of chillies, $£ 19,036$, hides and skins, $£ 35,515$, and rubber, $£ 5,695$. By 1911-12 cotton exceeded in value all other exports together-cotton $£ 230,850$, compared with $£ 136,725$ other goods (hides and skins, $£ 52,382$; chillies, $£ 16,658$; simsim, $£ 7,048$; ghee, $£ 5,819$, and rubber, $£ 4,442){ }^{2}$

The serious outbreak of sleeping sickness around the northern and north-western shores of the lake necessitated the conversion of all steamers from wood to oil fuel, so that it was no longer necessary to risk lives by cutting fuel for the boats on the islands where sleeping sickness was rampant. ${ }^{3}$

Examination of the map which shows the total traffic carried by railway craft during the period 1913-14 illustrates clearly the development which was general around the lake shores. Already through European exploitation of the zone practically all the present-day major centres had come into being. Kisumu handled in that year 55,942 tons, the vast majority of this being transit traffic which had not originated at Kisumu. The other large ports, Jinja, Port Bell and Mwanza handled 19,827, 17,401 and 12,506 tons respectively. Entebbe and Bukoba, the only other ports of size, lagged far behind the others, respective tonnages being 6,158 and 5,186 .

The prime interest of the map lies not so much in the actual size of the individual ports but in their distribution. At this early stage the dominance of Uganda in lake trade was fully established. Bukoba was clearly becoming the outlet for a prosperous agricultural region, whilst the size and isolation of Mwanza on the southern shore of the lake emphasised its role as the sole gateway from the lake to the large densely populated steppe region of Sukumaland and Nyamwezi to the south, and as the focus for the tratfic of the coastal fringe of the Speke Gulf. The comparatively recent development of the eastern lake shore and the Kavirondo Gulf is reflected in the small traffic of those ports. The poorer resources of the eastern lake regions are revealed in this early evidence of slower development, but the map gives no indication, other than the foundation of the outlets, of the future importance of the Kavirondo Gulf area.

The outbreak of war with Germany in August 1914, caused an interruption in the economic development of the Lake Victoria zone. By 1914 trade had so expanded that in the year 1913-14 traffic to the coast from the lake, 32,150 tons, was in excess of traffic to the lake from the coast, 27,609 tons. This expansion, necessitating the construction of the two large boats the Usoga and the Rusinga, which today provide the main lake service, was not restricted to British territory. The main Geman development was at Mwanza and Bukoba, but a beginning had been made at Musoma in open-

1. Vide "Mengo Notes", Ugancla Journal, Vol. 13, pp. 82 and 87, for a contemporary account of transport conditions between Kampala and Munyonyo.

2. H. B. Thomas, and R. Scolt, Uganda, London : 1935, p. 347. $1911-1912$ 
ing up the large German area to the east of the lake. The principal traffic from German territory was in groundnuts from the Mwanza area. In the year ending March 31st, 1914, 8,104 tons of goods were carried from Mwanza to Kisumu, and the principal commodities were as follows : ginned cotton, 662 tons; cotton seed, 1,030 tons; rice, 527 tons; groundnuts, 4,505 tons ; hides, 597 tons and ghee, 24 tons.

Despite its bad anchorage, Bukoba, the other German centre of importance, had by 1914 become one of the principal lake ports. Two commodities characterise the trade of Bukoba at this time-coffee, and hides and skins. The trade in hides and skins had grown by 1914 to 1,046 tons out of a total for the whole lake of 2,523 tons. This traffic was to suffer an eclipse during the war period from which it never recovered, leaving coffee as the principal export. Under German encouragement production of coffee in the Bukoba District had increased until in 1914, out of a total of 1,045 tons of coffee exported from the lake ports to Kisumu, Bukoba provided 430 tons. This production was practically all native-grown coffee of the "robusta" variety. It is interesting in this respect to contrast the production of coffee in Bukoba District with Uganda production. Cotton had become the African cash crop in Uganda, and the production of coffee was mainly from non-native plantations and was the "arabica" variety. There had been a long established African production of "robusta" coffee in the Sese Islands, leading to a considerable trade with the mainland in the 19th century, the coffee being used for chewing ; but the evacuation of the islands, on account of sleeping sickness, had put an end to a promising trade which in 1902 had an export value of $£ 892.1$ Uganda coffee in the bulk, then, was "arabica", originally planted as a temporary crop among the rubber trees on European estates, and in 1913 there were 10,000 acres (including coffee under rubber) on European plantations. ${ }^{2}$ For the most part, the early plantations were in $\mathrm{Kyagwe},{ }^{3}$ and the opening of the port of Kibanga in 1913 was to serve this coffee zone, 98 tons of coffee being shipped in that year. * About 1912, European plantations were opened up rapidly in Masaka, Mubende and Busoga Districts, the developments in Bunyoro and Toro coming slightly later. Port Bell was the main Uganda outlet for this coffee export, handling 394 tons in 1913-14.

The outbreak of hostilities threw into marked relief the essential unity of the lake basin and the serious consequences resulting from political disunity within the zone. The immediate consequence of the war was the total cessation of all traffic between the southern lake ports and Kisumu, and the resulting decline in the tonnages of the commodities peculiar in the main to the German areas, viz., rice, groundnuts, hides and skins, coffee and beeswax. More serious however, for the railway authorities, was the inevitable dislocation of traffic from the British zone. In September 1914, the Rusinga, finally completed and launched, joined the lake flotilla, the whole of which was concentrated at Port Bell. All steamers were fitted with guns and armed, and all were taken over for lake patrol work, with the exception of two left for ordinary traffic. ${ }^{5}$ At the same time a slump in the world price of raw cotton resulted in a certain proportion of the crop being lost, as the native growers were unwilling to carry the crop any great distance for a low price. Seed cotton ceased to be sent to the Kampala and Entebbe ginneries and cotton seed became a drug upon the market. At the same time the reduced buying of cotton resulted in a decrease in the quantity of the machinery which was being imported for what had lijtherto been the rapidly developing ginning industry.

During 1915-16 the situation seriously deteriorated. The railway authorities were left with only the Clement Hili, the Rusinga, the steam tug Huseni

1. J. D. Tothill (ed.), Agriculture in Uganda, London : 1940, p. 291

2. Ibit.l., p. 315

4. Ibid., p. 315.

4. Anmal Report of the General Manager of the Uganda Railway 1913-1914. 
and two 50-ton lighters; all other craft were placed at the disposal of the Navy. German attacks upon the railway line in the neighbourhood of Voi at times brought traffic nearly to a standstill. During November and December 1915, the export trade of Uganda practically ceased. From November 1915 to September 1916, there occurred a period of great congestion, and the trade of Uganda was carried on only by the storing of goods in godowns all along the line. In June 1916, a total of 9,143 tons of goods were held up for transport at the various ports on Lake Victoria and Lake Kioga.

The capture of Mwanza in July 1916, however, ensured the restoration of normal conditions on the lake by December of that year, and the resumption of trade, considerably reduced in the case of Mwanza, with the exGerman ports. The rice mills on Ukerewe Islands were repaired and trade restored. The coffee trade of Bukoba was resumed more vigorously than before as shown by a comparison of the 1916-17 figure of 980 tons with that of 430 tons for 1913-14.

Despite the cessation of actual hostilities on Lake Victoria, the trade of the region remained upset by the continuance of the war elsewhere in East Africa and Europe. The flotilla reverted to the military control on January 1st, 1917, and for the rest of the war traffic was handled by two boats assisted by tugs and lighters. It is significant that the traffic was easily moved by this reduced flotilla.

The severe U-boat warfare towards the end of the war resulted in a restriction on both the imports and the exports of East Africa, a situation which was prolonged into the period of peace. The lack of ocean-going shipping and the shortage of goods in Europe suitable for import into East Africa reacted severely upon the commercial life of East Africa ; and the curtailment of exports from the territories inevitably led to a reduction of purchasing power.

To make matters worse, 1917 and 1918 were years of drought and severe famine in East Africa and resulted in a considerable decrease in the availability for export of country produce. The following year, 1919-20, is noteworthy for the price fetched by Uganda cotton on the Liverpool market, the price rising to $59.15 \mathrm{~d}$. a pound, and frequently averaging $50 \mathrm{~d}$. a pound. ${ }^{1}$ This inflated market price should be remembered in comparing values of exported cotton. In 1911-12 20,000 bales were exported at a value of $£ 230,850$ and in 1918-19 36,000 bales at a value of $£ 965,951$. The explanation in the immediate post-war period of the steep rise in the value of exports, although the actual volume of traffic was below pre-war levels and many ships of the flotilla were laid up, lay clearly in the boom market.

In 1920-21 the sellers' market crashed in a world-wide trade depression with a catastrophic fall in prices. Uganda cotton growers encouraged by the high prices of the previous year had increased the area under cotton from 155,000 to 207,000 acres and the crop jumped in a single year from 47,000 to 81,000 bales. It was singularly unfortunate that this record crop should have coincided with a fall in world prices, and the Uganda Government had to enter the market as a buyer in order to preserve confidence amongst the growers. ${ }^{2}$ In commodities not subsidised in this way by the Government, there was a sharp decline in export, particularly in hides and skins which fell from 5,425 tons in $1919-20$ to 1,434 tons in $4920-21$, and to 213 tons for the nine months ending December 31 st, 1921.

The end of the financial year of the railway was changed from the 31 st March to the 31st December at the end of 1921, and that is a convenient date to close the first period of the railway age, as 1922 saw a revival of trade and an improvement in traffic.

The map which shows the total traffic carried by railway craft during

1. H. B. Thomas and R. Scott, Uganda, London : 1935, p. 132.
2. Ibid., p. 132 . 
the year ending 31st March, 1920, is worth comparing with that previously described for 1913-14. Of the six intervening years, four had been occupied by war and two by the aftermath of war. The comparison reveals the stagnation, and in some cases the decline, in the development of the lake regions. The total traffic passing through Kisumu had fallen by 11,266 tons to 44,676 tons. Perhaps the most striking feature of the map is the depression of Mwanza, and in contrast, the maintenance of the trade of Bukoba at nearly pre-war level. The early growth of the Uganda ports of Jinja and Port Bell had been checked and the decline of Entebbe with the firm establishment of Kampala as the commercial capital had become apparent. Depression of trade emphasised the difference in the wealth of natural resources of the eastern and the western shores. Whilst on the western and northwestern shores a few minor ports show signs of expansion, e.g., Bukakata, Kibanga, and Mjanji, the eastern region shows a decay of the little development which had previously been achieved. Musoma, now established as the headquarters of the British administration in the region, alone shows any signs of life. The decline of trade in the Tanganyika frontage on the eastern side of the lake in contrast with the position on the western shores of the lake results mainly from the fact that the less favourable character of the area failed to attract the British to carry on the efforts of the Germans. More difficult of explanation is the depression in the Kavirondo area. The answer probably is that with the distraction of war, administration had in the main failed to maintain its hold on what were then admittedly primitive peoples, and that the lack of consumer goods resulted in a decline in the interest of the Luo in growing extra crops for export.

Briefly, the end of the first period saw the lake services carrying a total volume of traffic which was less than the traffic carried at the beginning of the war. After the steady growth of trade in the first twelve years this set-back was serious and disheartening, but the picture was not completely black. The confidence of the cotton growers in Uganda was such that despite the world market, the export of cotton for the nine months March to December, 1921, was the highest then on record, 13,322 tons, ${ }^{1}$ and there was also an increase in the export of coffee, groundnuts, and cotton seeds, with the result that those nine months saw the heaviest rate of export traffic then on record, 28,987 tons being shipped to Kisumu from all ports.

\section{The Period of Railway Expansion, 1922-1931}

The next period, 1922-1931, was one of economic recovery and expansion of trade which culminated in the extension of the two railway systems of East Africa. One extension, that to Jinja in 1928 and its later continuation to Kampala in 1931, diverted much traffic from the lake; and the second extension, also completed in 1928, from Tabora to Mwanza, opened up a second outlet to the lake region and thus introduced complications into the flow of trade. The period came to an end, as did the earlier phase, with a great world-wide depression of trade.

From 1922-24, the trade of the lake zone recovered from the effects of the war and its aftermath, and boats previously laid up were brought back into commission in 1924 to cope with a serious state of traffic congestion. In 1922 total lake traffic for the year approximated to that of 1913-14, the amount being 55,722 tons. By the end of 1924 traffic had more than doubled $(122,517$ tons in that year), and by 1926 iPhad trebled, reaching the figure of 162,689 tons. This expansion can be related to a succession of good climatic years which led to large maize crops in Kavirondo and a great expansion of cotton production in Uganda.

1. Ammal Report of the General Manager of the Uganda Railway for the year ending 31/12/1921. 


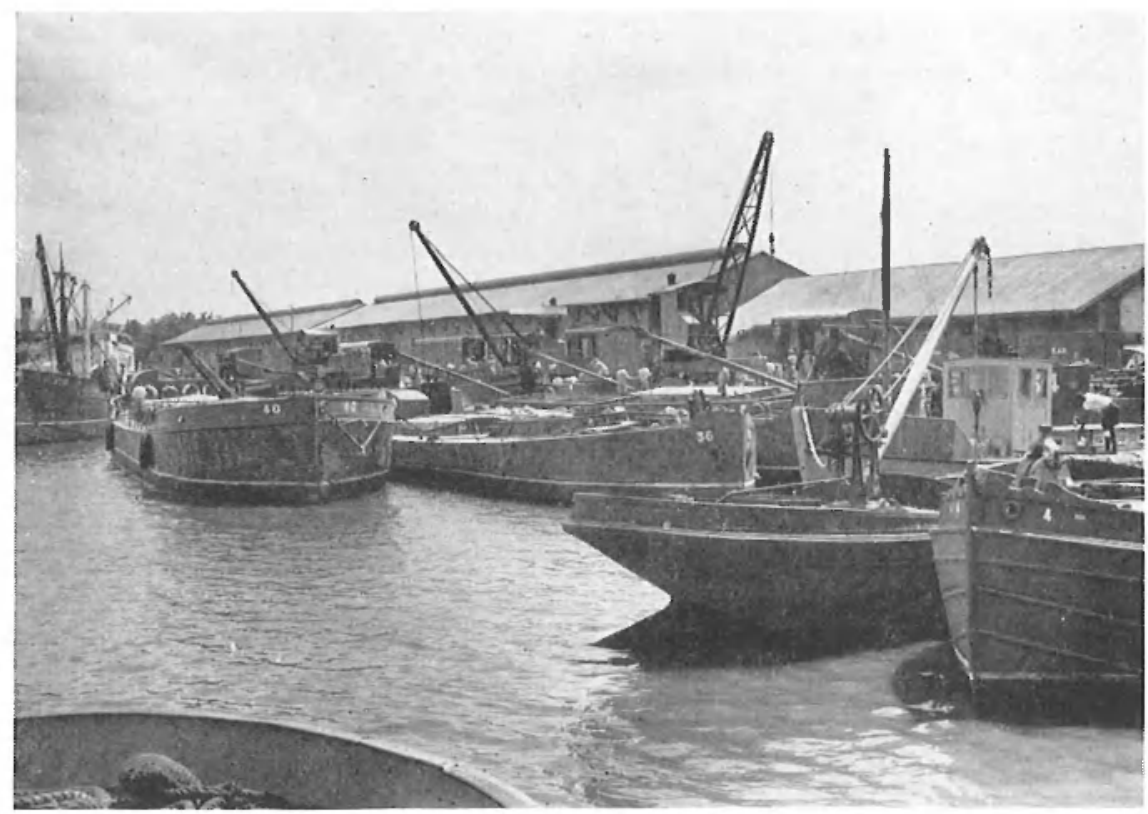

4 Kisumu Dock: lighters being loaded. Note the railway siding alongside the dock and the travelling cranes.

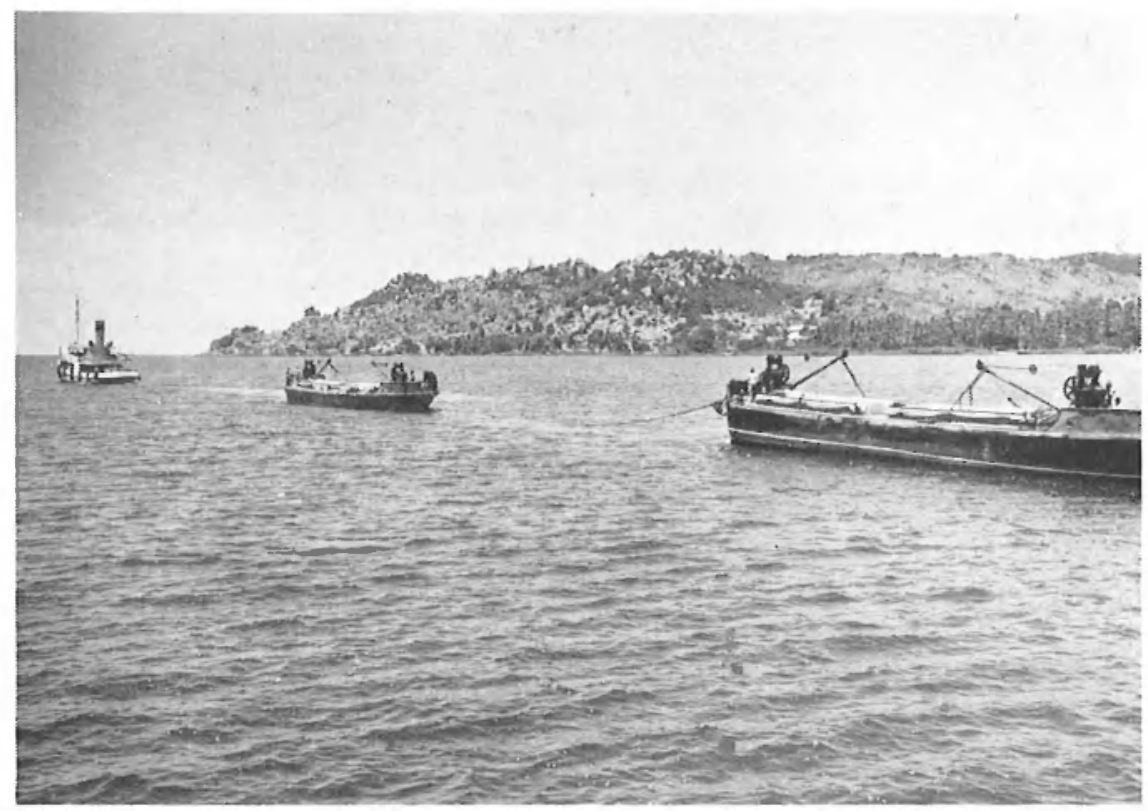

5 The steam tug Buganda and train of lighters leaving Mwanza en route for Nungwe and Bukoba. This is typical of the tug and lighter service which carries the traffic of many of the lake ports. Two tugs operate in the open lake and one in the Kavirondo Gulf. On the extreme right of the background is the dhow beach at Kirumba. 
of the hinterlands of these two ports. The hinterland of Mjanji comprised much of the plains stretching northwards between Mount Elgon and Lake Kioga, whilst that of Sio was narrowly confined to the area, difficult of access, between the two large rivers, the Sio and the Nzoia. The development of Musoma and the Kavirondo Gulf ports is clearly visible, though the lack of any good transport service in the Gulf must have retarded development, particularly of the southern ports of Homa Bay and Kendu Bay.

The year 1928 is an important one in the history of lake trade. In that year the port of Mwanza was linked by rail to the Tanganyika Central Railway, and the Kenya and Uganda Railway reached Jinja. ${ }^{1}$ The effect of this railway development was an immediate decline in the tonnage carried on the lake. The authorities realised that these new transport developments would have an adverse effect upon lake traffic. and this resulted in a search for new ports and in particular close examination of the Kagera River as a possible new outlet for the developing district of Ankole and for the Province of Ruanda which at that time was perhaps optimistically expected to develop as the Belgian "Kenya".

An improved tug and lighter service was given to the Kavirondo Gulf area in 1928, resulting in the enormous increase of 593 per cent. in the traffic of the small ports of the Kavirondo Gulf with Kisumu for 1929 as compared with 1925. As was to be expected however, the completion of the Kisumu to Butere railway line on 1st November, 1930, resulted in a diversion of traffic from Asembo Bay and contributed its share to the sharp decline in the traffic of the local ports of the Gulf in 1930 and 1931.

Other ports developed during the period of 1928-29 were the timber ports of Sango Bay and Katimeru, opened on behalf of the Uganda Government. All these new ventures, combined with an increase of trade at those ports unaffected by railway construction, offset for a time the adverse situation created particularly by the railway extensions in Uganda. The ports affected by the new railways were Jinja, Buluba, Mjanji and Mwanza. These four ports together in 1926 had a traffic with Kisumu amounting to 92,297 tons. This traffic shrank in the first nine months of 1928 to only 10,549 tons. In the case of Mwanza the traffic declined steeply mainly as a result of the movement of groundnuts and cotton by railway to Dar-esSalaam. From this date it would be true to say that the fertile districts of Kwimba and Mwanza cease to play a major part in lacustrine trade. The following tonnage figures for Mwanza pier show the decline clearly, 21,672 tons in 1926,17,861 tons in 1927, 12,316 tons in 1928 and 10,101 tons in 1929.

Similar declines are to be observed in the figures for Jinja and Mjanji. At Jinja the total traffic with Kisumu declined from 66,442 tons in 1925 to 3,722 tons in 1928 and 1,005 tons in 1929. At Mjanji the decline was so severe that it ceased to be a regular port of call for steamers and a tug and lighter service was substituted. A comparison is interesting with its neighbouring port of Sio which, separated to the south-east by the River Sio, was unaffected by the railway extension.

TABLE 3

MJANJI AND SIO PORTS : TOTAL TONNAGE TO AND FROM KISUMU

\begin{tabular}{|c|c|c|c|c|c|c|c|}
\hline Port & & & 1925 & 1926 & 1927 & 1928 & 1929 \\
\hline Mjanji & . & $\ldots$ & 14,971 & 12,528 & 7,325 & 282 & 71 \\
\hline Sio & . & $\ldots$ & 334 & 730 & 765 & 920 & 1,433 \\
\hline
\end{tabular}

1. The title of the Ugunda Railway was altered to that of the Kenya and Uganda Railway in 1926. 
In 1928 the total lake traffic naturally showed a reduction over that of 1927, and the slow general decline continued until 1930, despite a partial recovery during 1929 due to the increase in trade at ports not served by the railway, and the buoyant market which from 1927-29 had been increasingly stimulating the export of such commodities as hides and skins and tin. ${ }^{1}$

In 1931 the railway extension from Jinja to Kampala was completed and much of the traffic of Port Bell diverted to the railway. At the same time the slump which had been forecast by falling prices in 1930, culminated in 1931 in the "economic blizzard" which affected the whole world. These two factors are clearly reflected in the following table :-

TABLE 4

LAKE VICTORIA TRAFFIC IN TONS, 1928-1932

\begin{tabular}{|c|c|c|c|c|c|c|}
\hline & & 1928 & 1929 & 1930 & 1931 & 1932 \\
\hline Inward to Kisumu & . & 57,996 & 70,038 & 55,258 & 25,845 & 27,672 \\
\hline $\begin{array}{l}\text { Outward from } \\
\text { Kisumu }\end{array}$ & .. & 41,738 & 59,334 & 44,557 & 15,809 & 9,537 \\
\hline $\begin{array}{c}\text { Intermediate Port } \\
\text { Traffic } \quad . .\end{array}$ & .. & 8,730 & 11,264 & 10,334 & 5,489 & 3,123 \\
\hline TOTAL & .. & 108,464 & 140,636 & 110,149 & 47,143 & 40,332 \\
\hline
\end{tabular}

The year 1931 then is a clear date in the trade of Lake Victoria, marking both the end of railway development with its inevitable repercussion on the flow of trade, and also a catastrophic fall in total trade which was associated with the world depression.

\section{The Phase of Recovery and Adjustment, 1932-1939}

The phase 1932-1939 began with a trade depression which, combined with the completion of a phase of railway development, resulted in a great fall in the trade of Lake Victoria. Trade was recovering rapidly when in 1939 war once again occurred and brought unusual conditions which require separate treatment.

Comparison of the maps showing total traffic for 1926, 1932 and 1938 shows plainly the depression and recovery of trade during this phase. The outstanding features of the map for 1932 are twofold ; the complete disappearance of Jinja as a port and the decline of other ports which had been of major importance. The construction of the railway line to Kampala is clearly responsible for the fall in the tonnages of Port Bell and Mjanji, and for the complete abandonment of Jinja. These changes are reflected in the smaller traffic passing through Kisumu, which in addition had henceforth to share with Mwanza the extra-lacustrine traffic. The lake traffic of Mwanza naturally shows a fall as the result of the diversion of much of its traffic away from the lake by the railway. In those areas away from the effects of railway construction, slight increases in trade had, even in 1932, been made over that of 1926, e.g., at Bukoba, Bukakata, Katebo, Homa Bay and Kendu Bay. There is also at this period the appearance of the new port of Nyakanyasi on the Kagera River, together with the port at its mouth, Busungwe Island.

The picture of depression, of craft laid up in Kisumu harbour, should be

1. H. B. Thomas and R. Scott, Uganda, p. 347. 
borne in mind, for it lies at the core of the history of the period. Costly railway lines had been built, and for the first time the two East African railway systems were jointly tapping and competing for the traffic of the wealthy lake basin. The differences in the rating policies of the two systems gave rise to the private competition of the dhows for the now considerably reduced traffic. All parties concerned were desirous of attracting the maximum traffic to their services, and as a consequence the period is one in which a rate war was conducted against the dhows, and one in which several commissions attempted to solve the differences arising between the two railway systems over the diversion of Tanganyika traffic through Kisumu and Mombasa. The necessity of making the new and costly rail extensions in Uganda and Tanganyika pay became a prime consideration for the railway authorities in both countries. In Tanganyika the loss in great part of the valuable transit traffic from Belgian Ruanda-Urundi and the copper traffic from the Katanga Province, made it highly desirable that a greater flow of traffic should come from the Tanganyika Lake Province. On the other hand, in Uganda the necessity of preventing diversion of traffic from the new railway to the lake route, either by their own craft or by the dhows, was balanced by the need to find alternative traffic for the idle railway craft. Consequently there was a great reluctance on the part of the Kenya and Uganda Railway to surrender any trade from the Tanganyika zone of Lake Victoria.

By 1932, the date when this phase begins, the search for new trade had begun. The Kagera River, difficult to navigate because of its swift current, its sharp bends and the sandbanks exposed at low water, had been opened to navigation in November 1931, and the river port of Nyakanyasi established. The traffic from this port was, and still is, very largely in tin ore from the mines of Ankole and Bukoba Districts, and in supplies of timber machinery and food to the mines. In 1932, 416 tons of tin ore were carried away from this port.

The same year saw trade at Bukoba greatly facilitated by the construction of a breakwater and of a new steel pier. The practice of discharging into lighters from the steamers anchored out in the open lake, had made it frequently impossible to load or unload any cargo. This long needed improvement came, when an increase in the value of the coffee produced in the area gave increased purchasing power to the Africans, and led to a consequent rise in the value of imports from $£ 92,018$ in 1931 to $£ 109,407$ in 1932.1 These goods, 6,004 tons, were mainly from neighbouring territories and comprised such items as cotton piece-goods, blankets, wearing apparel and sugar. The same year saw the export of three tons of fire-cured tobacco from the Biharamulo District, a traffic which was to grow considerably, to eighty tons by $1939 .^{2}$

Recovery of trade throughout the lake basin was slow but steady. During the period under review, there were no spectacular increases of traffic at any one port, but as comparison of the maps showing trade in 1932 and 1938 will show, an all round increase in the volume of trade had taken place by 1938, but in the aggregate was still far behind that of 1926 . The recovery in trade was, of course, coincident with the general recovery of trade elsewhere, but in some areas definite steps to improve or foster new production must be taken into account. In the Bukoba area, the ravages of the coffee-berry borer beetle had for some been seriously affecting the quality of coffee, and by 1931 the deterioration was so marked that the value of the crop had fallen by 73 per cent ${ }_{n}$ In September 1933, drastic prophylactic treatment against the borer was enforced and the crop, steady between 1928 and 1933 at about 5,200 tons, jumped from 6,898 tons in 1934 to 7,472 tons in 1935 , with improved quality.

1. Anmual Trade Report of Tanganyika Territory 1932.

2. Provincial Commissioner, Lake Province, Tanganyika Territory, Almual Report 1932. 
In Musoma District, the production of ghee on a commercial scale had been practised since German times, but the ghee had been poor in quality. ${ }^{1}$ In 1932 a great step forward was taken, when an arrangement was made with the Native Treasury to finance the purchase of separators on a hire purchase basis, payment being made in the form of one debe of ghee per month. By 1939 it was estimated that there were 1,500 separators in the district. Exports of ghee rose rapidly as the following figures show :- ${ }^{2}$

TABLE 5

EXPORTS OF GHEE FROM MUSOMA DISTRICT

\begin{tabular}{|c|c|c|c|c|c|c|}
\hline Year & & & & Cwrs. & Value (S/hs.) & $\begin{array}{c}\text { Approximate Price } \\
\text { per } 36 \mathrm{lbs} .\end{array}$ \\
\hline $\begin{array}{l}1926 \\
1932 \\
1933 \\
1935 \\
1936\end{array}$ & $\begin{array}{l}\cdots \\
\cdots \\
\cdots \\
\cdots\end{array}$ & $\begin{array}{l}\cdots \\
\cdots \\
\cdots \\
\cdots\end{array}$ & $\begin{array}{l}\cdots \\
\cdots \\
\cdots \\
\cdots\end{array}$ & $\begin{array}{r}1,736 \\
2,950 \\
5,442 \\
10,457 \\
13,788\end{array}$ & $\begin{array}{l}157,301 \\
157,294 \\
221,975 \\
475,260 \\
749,163\end{array}$ & $\begin{array}{l}30 / 00 \\
18 / 00 \\
13 / 00 \\
15 / 00 \\
18 / 00\end{array}$ \\
\hline
\end{tabular}

Despite the introduction in 1936 of a new technique of ghee production the ghee remained sub-grade in quality until regulations for the control of its manufacture were enforced in 1941.

The improvement in agriculture and its allied industries was a feature of the Lake Province of Tanganyika as a whole. During the period 1932-1939 the growing of cotton along the lake shore margins of Mwanza, Kwimba and Musoma Districts extended, and railway craft began to serve such ports as Nansio and Mwanyire in the Speke Gulf.

The discovery of gold in the Kavirondo Province of Kenya brought about an increase in the traffic of Asembo Bay, which was suitably placed as an outlet for the Central Kavirondo mining area. Homa Bay, in a similar position in relation to South Kavirondo, was already in 1934 importing pit-props and tramway material for the Kenya Consolidated Mines Ltd., of South Kavirondo. By 1937 Kisumu was handling fair quantities of mining materials for the gold mining areas ; 667 tons of iron and steel goods, 64 tons of chemicals and 632 tons of machinery. Gold mining in the Musoma area began in 1934 with an output of 1,975 troy ounces, a figure which rose steadily each year to reach 50,366 troy ounces in 1939. This valuable export does not figure in the total tonnages as shown on the map, but the increased importation of mining materials swells the import figures of the various ports serving the mines. Another area of gold development was at the isolated mine of Geita in the south-western extremity of the lake region. This mine is served by the port of Nungwe. Reached by a tug and lighter service, Nungwe functioned at that time purely as the outlet for the mine which today is one of the largest in East Africa.

The expansion and development in agriculture was not confined to the Lake Province of Tanganyika. Examination of the map which shows the total traffic for 1938 reveals the remarkable expansion in traffic passing through the port of Bukakata. The district whick it serves is a rich agricultural area, and a centre of native-grown "robusta" coffee. The expansion in coffee production is simply demonstrated by the figures of acreage under "robusta" for Masaka District, which increased from 169 acres in 1925 to

1. The ghee, known as " Kibuyu ghee ", was made by boiling butter which had been churned from whole milk, or skimmed cream which had been shaken in a gourd or beaten in a cooking pot with a wooden spoon. The butter, rancid to begin with, had, by the time sufficient was collected to boil, grown a mould, and was dirty-acid, and insect-ridden. The introduction of separators from South Kavirondo by the Luo in the

2. Extracted from the Musoma District Book by kind permission of the District Commission 
5,700 acres in 1935 . In the same year, $1935,185,000$ seedlings were distributed in the district for further planting. ${ }^{1}$ The trade of the port of Katebo, which serves the area intermediate between Masaka and Entebbe, shows an expansion from 4,354 tons in 1932 to 9,715 tons in 1938, the port acting principally as an outlet for cotton, but also shipping coffee, beans and timber. The Sese Islands too, show a small revival in trade. Katebo, as part of its traffic, was developing its function as a collecting and distributing centre for the Sese Islands, a function shared with Entebbe, and to a lesser extent with Port Bell.

During this period the river port of Nyakanyasi had built a connection with the Ruanda-Urundi area of the Belgian Congo, for which it imported cotton goods in quantities which increased from 18 tons in 1934 to 64 tons in 1938. At the same time Belgian coffee from the Ruhengeru area, making a journey of over 200 miles by road via Kisoro and Kabale, was booked at Nyakanyasi for export.

The revival of trade in the Uganda area is not fully shown, as the railway, providing an alternative outlet for much of the region, certainly carried to and from Kenya the bulk of the traffic of Mengo District and the Northern and Eastern Provinces. With the revival of trade, Jinja does not reappear as a port. Nor does Mjanji again outstrip Sio, for in 1938 Sio had the larger traffic, 2,222 tons compared with 1,646 tons for Mjanji. Before the 1939-1945 war, cotton growing was a marked feature of the agriculture of the Kavirondo Province, and the function of Sio was principally as an outlet for the cotton grown in that part of North Kavirondo which lies immediately to its east. Of the export traffic passing also through Kendu Bay, a third, approximately 1,200 tons, was cotton, and at Homa Bay about 700 tons of cotton formed between a third and a half of the exports. The Kavirondo Province was also a heavy producer of maize, the Yala area in Central Kavirondo producing about 6,000 tons of surplus maize for export, approximately 3,000 tons being shipped via Kisumu to the Musoma area. The production of ghee from the South Kavirondo area of Kenya had risen from 27,000 tins in 1935 to 31,000 tins in 1939, approximately 95 per cent. of the ghee produced in the Kavirondo Province coming from that area.

Examination of the map of total traffic for 1938 shows, in comparison with that of 1932, that trade within the lake region had made considerable progress towards recovering the position existing prior to 1929. In all areas, with the exception of the ports of the Emin Pasha Gulf, trade had not only recovered but gave evidence of healthy development in all the lake regions. Despite the slow development of the production of fire-cured tobacco in the Biharamulo zone, this somewhat inaccessible region no longer had services available through the port of Nyamirembe, and the disuse of this port was in 1938 the subject of correspondence between the two railway systems. The installation, late in 1940 by the Tanganyika Railways, of a motor launch service between Mwanza and Nyamirembe partly remedied the isolation of this part of the lake.

In examining the map, it should be borne in mind that the activities of the dhows, now at their zenith, are not shown. ${ }^{2}$ Nor does the map show the carriage by railway craft of goods from the Tanganyika ports on Lake Victoria towards Kisumu and away from Mwanza. The prosperity which was once again making itself apparent over East Africa, enabled the Kenya and Uganda Railways towards the end of this period to make considerable reductions in its rates. These reductions sewed only to emphasise the difference in wealth between the Kenya and Uganda Railways and the Tanganyika Railways, and from this disparity of wealth a number of problems arose.

1. J. D. Tothill (ed.). Agriculure in Uganda, 1940, p. 292

The map showing dhosy traffic in 1938 which is described in Chapter Three should here be compared with the map which shows the total traftic of Lake Victoria carried by railway owned boats in 1938 . 


\section{The War Period, 1939-1945}

The outbreak of hostilities with Germany in 1939 did not affect the trade of Lake Victoria in the manner of twenty-five years earlier. Although the lake basin was divided politically, British Imperial power alone was dominant over the whole region. Furthermore, the existence of the railway line from Tabora to Mwanza provided a valuable second outlet to the lake. Lake Victoria, for the first time, played a role in the north-south chain of Imperial defence communications, linking Cape Town to Nairobi, to Khartoum and to Cairo. There was no longer any necessity to concentrate the fleet in any one port for protection as in 1914, nor for arming the vessels.

The presence of large armies in the Middle East and in East Africa threw a strain on the resources of the railway. Demands for timber on a large scale, particularly timber suitable for railway sleepers, resulted in exploitation of the forests in the lake zone of Uganda. The ports of Katebo, Buwaya, Mpunge, Bussi and Bunjako served the forest areas to be found along the swampy shores and on the islands in the region of the mouth of the Katonga River, whilst Sango Bay and Bukoba acted as the outlets for the timber growing near the mouth and along the lower valley of the Kagera River.

Food supplies for the large armies in East Africa, together with the necessity for the territories themselves to be self-sufficient in food, led to a drive for increased production in food crops. Stress was also laid upon the production of industrial crops, and in the Lake Province of Tanganyika the cotton crop which had fluctuated between 20,000 and 40,000 bales a year between 1933 and 1939 , under the stimulus of war was raised in 1941 to 50,115 bales each of $400 \mathrm{lbs}$. weight.

The steady increase in production in the lake basin found the Kenya and Uganda Railways in difficulties. The demands, civil and military, upon the railway line were so great that in 1942 the General Manager of the Tanganyika Railways suggested that to ease the situation, more traffic should be routed via Mwanza and Dar-es-Salaam. In particular, it was proposed that all export products of the Tanganyika Lake Province, including Bukoba coffee not requiring processing, should be sent to Mwanza together with military traffic from Sango Bay (mainly timber). Imports for the Geita gold field and for Musoma, Bukoba and Mwanza should also, it was suggested, be imported via Dar-es-Salaam. In large measure these proposals were adopted, and as the table below shows, by the end of the war, a considerable diversion of traffic to Dar-es-Salaam from Mombasa had taken place.

TABLE 6

DIVISION OF TRAFFIC OF LAKE PORTS, TANGANYIKA, 1939 AND 1945

\begin{tabular}{|c|c|c|c|c|c|}
\hline Year & & & $\begin{array}{c}\text { K.U.R. \& H. } 10 \text { and } \\
\text { from Tanganyika } \\
\text { Ports } \\
\text { (Excluding Mwanza) }\end{array}$ & $\begin{array}{l}\text { Dar-es-Salaam to } \\
\text { Tanganyika-Ports }\end{array}$ & $\begin{array}{l}\text { Tanganyika Ports } \\
\text { to Dar-es-Salaam }\end{array}$ \\
\hline 1939 & .. & . & $\stackrel{f}{f}$ & $\stackrel{\mathfrak{f}}{4,590}$ & $\stackrel{f}{\mathfrak{f}}$ \\
\hline 1945 & $\ldots$ & .. & 39,979 & 13,085 & 11,207 \\
\hline
\end{tabular}

It will be seen that although the total value of the traffic of the lake ports of Tanganyika fell, the Tanganyika Railways' share of the traffic 
increased considerably. The fall was due to the effect of the war upon ocean transport and the curtailment of imports. The diversion was an artificial one which bore no relation to the normal trade routes. War-time controls, such as the import control regulations which stipulated that all imported goods had to pass through the capital of the territory concerned, were in great part responsible for this diversion of traffic.

The transport difficulties of the Kenya and Uganda Railways were not lessened by a succession of bad seasons after 1941, which, bringing famine to many parts of East Africa, resulted in the large-scale movement of grain to the famine areas. In 1943, famine conditions in Tanganyika resulted in large-scale movement of food from Bukakata to the affected areas via Mwanza. In 1944, famine in the Eastern Province of Uganda necessitated the importation of maize and wheat flour. In 1945 the continuance of famine conditions in Tanganyika resulted in further large-scale shipments of soya beans from Nyakanyasi and Bukakata to Tanganyika. The defeat by bad weather conditions of the campaign to grow more food did not apply to the Kavirondo Province of Kenya. In South Kavirondo, the fertile upland area of Kisii greatly expanded its production of maize, whilst the flat clay plains around the Kavirondo Gulf concentrated on the growing of groundnuts and of rice. The Kavirondo Province of Kenya showed a steady fall in the production of cotton as a result of the increased interest in the growing of food. This is reflected in the map which shows the total traffic carried by railway craft in 1944 by the decline in the traffic of Sio, Mjanji and Asembo Bay. The Luo labourer, mainly interested in stock-keeping and fishing, found the growing of cotton, with its exacting calendar and labour, a tiresome crop. The war-time propaganda for increased food production offered an excuse for a smaller production in cotton, and the spice and fun of "black marketing" rice and pulses, to say nothing of the profit, was an exceedingly attractive proposition to many Africans. The increase in maize production is shown by the amounts changing hands in the markets of South Kavirondo, the number of $200 \mathrm{lb}$. bags of maize rising from 69,657 in 1942 to 87,550 in 1943 and to 105,427 in 1944. Kendu Bay and Homa Bay were the ports most affected by this increase in maize production. Road and rail services to the north of the Kavirondo Gulf effectively tapped that region, and a decline in the traffic of Asembo Bay from 1,507 tons in 1938 to 611 tons in 1944 is evidence of improvement of these other forms of transport. To the south however, the lack of a railway, and the long tortuous road journey to Kisumu, has emphasised the role of the lake as the chief means of extracting the produce from this wealthy agricultural area. At Homa Bay and Kendu Bay, control points and large storage godowns have been built for the maize and other grains, such as wimbi, mtama, simsim and pulses, all of which flow through these points.

Examination of the map showing the total traffic for 1944 reveals many of the points mentioned above. The demands for timber are to be seen in the expansion of existing ports and the appearance of new ones in the area between Bukoba and Entebbe. The institution, late in 1940, by the Tanganyika Railways of a heterogeneous collection of craft to serve the areas within a hundred miles of Mwanza was coincident with development in the southwest of Lake Victoria. This is reflected by the appearance of Buchenzi, an outlet for a cotton area, and the restitution of the fortnightly tug service to Nyamirembe. Improved road facilities in the Biharamulo District, together with the lake services, fostered development, wnnages of traffic at Nyamirembe rising from 548 tons in 1944 to 940 tons in 1948. The difficulties of getting machinery for the gold mines were mainly responsible for the decline in the traffic of Nungwe. The rise in production of agricultural commodities in South Kavirondo is shown by the increase of traffic at Kendu Bay from 5,273 tons in 1938 to 10,637 tons in 1944 and at Homa Bay from 2,274 tons in 1938 to 4,456 tons in 1944 . Of note, in the same region, is the 
spectacular development of the traffic of Kuwur. This small port, consisting merely of an open pier, is within a few yards of the site of a lime works. The limestone, of different grades, is quarried three miles away on the slopes of Homa Mountain, which rises steeply from a narrow raised beach lying behind the lime works. The demand for lime during the war, a demand accentuated by an acute shortage of imported lime, explains the large traffic; 12,805 tons of lime passed through Kuwur in 1944. Much of the high grade chemical lime was moved across the lake to the two sugar factories of Uganda, and other lime went to the gold mines, e.g., Geita, using the cyanide process of extraction.

The end of the war did not bring any great change to the character of the lake trade. There was a slow natural re-adjustment to the changed conditions of peace. In 1940 as in 1914-15 the outbreak of war brought a fall in trade, but a fall by no means so marked, and the recovery in 1941, 1942 and 1943 was more rapid and more marked than in 1916-17 and 1917-18. The later war, unlike its predecessor, acted as a stimulus to trade. After the initial setback resulting from public caution at the beginning of the war, a greater flow of traffic than in the immediate pre-war years began.

Concluding the historical survey of the trade of Lake Victoria, two final points are worthy of emphasis. Since 1918-19 the tonnages of goods exported from the Lake Victoria region have surpassed the tonnages of goods imported into the region. Undoubtedly the value of goods imported, mainly manufactured articles, will ton for ton be higher than that of the exported goods. In the absence of figures no firm conclusions should be drawn, but the excess of exports over imports suggests that the Lake Victoria basin has a favourable balance of trade. The second point lies in a comparison of the maps of total lake traffic for 1913-14 and 1944, which reveals the fact that all the major centres of lake trade were established at an early stage in the history of the lake, and that although time has brought changes in the volume of traffic, the appearance of new ports and the disappearance of some old ones, the broad general pattern was still fundamentally the same in 1944 as it was thirty years earlier. 


\section{CHAPTER III}

\section{THE. DHOW TRADE OF LAKE VICTORIA : ITS RISE AND DECLINE}

\section{Origins and Organization of the Dhow Trade}

The beginnings of trade on Lake Victoria are obscure. Such trade as existed before the development of Buganda under British administration was extremely small and limited to occasional movements of ivory and slaves, by dhow or canoe, southwards from Buganda to Kagei. The early trading contacts of Buganda came not across the lake but overland from the south, through Karagwe. We know that as early as the reign of Semakokiro, Kabaka of Buganda, who died about 1815, trade existed between Karagwe and Buganda, ivory being bartered for blue cotton cloth, copper wires and cowrie shells. ${ }^{1}$ These early traders in Karagwe were probably Swahili or Nyamwezi, and it was not until about 1848 that Arab traders reached the court of Suna. ${ }^{2}$ In their case too, the contact was overland through Karagwe. These early Arab traders, having incurred the displeasure of Suna, were forbidden to cross the Kagera River shortly before Suna's death in $1856 .{ }^{3}$ Movement on the lake at this time was possibly only by the use of the sewn canoes of the Ganda, a mode of transport rendered dangerous by the storms of the lake and the unfriendly tribes around the south and south-western margins of the lake. ${ }^{4}$ Stanley, in circumnavigating the lake in 1876 , noted the astonishment of many of the natives at the sail he used on his small boat ; their ignorance of the sail strongly suggesting that Arabs had not previously made any lake voyages. No precise date can be given for the appearance of the first commercial sailing vessel, but after 1880 odd references to dhows, canoes and small launches begin to occur, these vessels carrying such lake traffic as there was before the arrival of the railway steamer services.

The early dhow trade was between the Mwanza and Buganda areas, as Mwanza was the only point on the lake which could be easily reached from the coast, and Buganda was the only trading area in the lake basin. The first dhows were Arab owned and were largely concerned with the slave trade. As the drive against slavery increased in vigour about the same time as the first dhows were making their appearance, Arab dhow trade never became large and as late as 1894 canoes were still being used for transport between Entebbe and Mwanza. ${ }^{6}$ However, the dhow trade boomed for a brief period at the end of the century, as German influence extended in the Mwanza and Bukoba areas. German traders became established in Bukoba and Kampala, and a regular dhow service prior to 1903 was run between Mwanza, Entebbe and Bukoba.

In 1903 the beginning of the railway steamer service brought the withdrawal of the dhow service from Bukoba and its limitation to the local distribution of goods in the Mwanza and Musoma areas. It was not until 1925 that a recrudescence of the dhows begare when an increasing Indian population around the lake shores created a demand for rice. This could be carried at cheaper rates than by the railway secyices and dhow competition on the main routes began to grow. In 1925 six dhows of a total tonnage of

Sir Apolo Kagwa, BaseKabaka ba B:aganda, p. 88

Sir John Milner Gray, Uganda Journal, 1947, Vol. XI, p. 80.

3. J. H. Speke, The Journal of the Discovery of ihe Nile, 1863, p. 205.

4. Vide H.M. Stanley, Through the Dark Cominem, 1878.

5. Sir Frederick Jackson, Early Days in East Africa, London : 1930. 
107 tons trading from Mwanza made their appearance. A growing Indian and native market for rice and cassava flour resulted in a rapid increase of the number of dhows to 18 with a total tonnage of 457 tons by 1927 ; and at this time there was approximately one dhow arrival every month at Bukoba. In the main the bulk of the dhow trade was centred in Tanganyika waters, far fewer dhows being registered in Kenya and Uganda.

The organisation of the dhow trade is an interesting study in commercial opportunism. Almost without exception the dhows were owned by Indian traders who were not transporters, but general merchants owning their own dhows. The precise number of traders is not recorded, but in 1937, of the 100 dhows in operation, 81 were divided between 37 owners. In the same year, when the dhow trade was nearing its peak, the gross tonnage was 2,416 tons, making an average tonnage per dhow of 24 tons. In 1937 an estimate of the total capital invested in the dhow trade put the figure at $£ 25,000,{ }^{1}$ and in 1940 approximately 2,000 people were said to be employed in the trade. ${ }^{2}$

The bulk of the dhows, approximately 80 per cent., were concentrated at Mwanza, and were built on a gently shelving beach at Kirumba, a mile and a half to the north-east of Mwanza on Mwanza Gulf. The builders were workmen brought up from the coast, particularly from Lamu, an old centre of the Arab dhow trade in the Indian Ocean. ${ }^{3}$ These master craftsmen constructed the dhows in the traditional manner, the cost varying between $£ 250$ for a 10 -ton dhow and $£ 600$ for a 70 -ton dhow. ${ }^{4}$

The crew of a dhow varied according to its size, but a large dhow had a master, an assistant master and a crew varying in number from 14 to 20 sailors. Conditions on board these dhows were primitive, a sheet of corrugated iron often forming the only shelter for the crew, and the galley being an open fire in a bucket wedged between three stones. No passengers were carried and life-saving devices were largely absent. Navigational instruments were not used, a course being set by the sun and the stars. The hold for the cargo was open and a pent roof of corrugated iron formed the only shelter from the weather. Naturally the risk of loss and damage to goods was high, damage to cargo being sometimes as high as five per cent. Because of this, dhow owners could only insure against total loss and for limited amounts per consignment and cargo. The inability of the dhow owners to insure against damage and the fact that bank advances were given only on goods travelling by the Kenya and Uganda Railways system, meant that, until at a later stage in the development of the trade very strong inducements bccame operative, the dhows did not handle much high-class transport.

The cost of operating a dhow depended on its size and the length of its commission during the year, varying between $£ 95$ and $£ 240$ for an eightmonth period.5 The peak season lasted for about six months in a year. During this period all available dhow capacity was used and dhow rates increased, the rates falling in the slack season when competition for traffic increased. Many of the large owners used the slack season for repair work, considerable parts of the dhows being replaced, the net result being that a dhow was never scrapped but almost completedly replaced at least three times in 20 years. ${ }^{6}$ It is noteworthy that a dhow was not considered profitable to run unless it was in fairly constant use, owing to the rapid decay if a vessel was laid up. It was estimated that a vessel in regular commission needed repair every 18 months, but if laid up every three to four months. ${ }^{7}$

In 1937, Brigadier-General Sir H. Osborge Mance estimated that a

1. Rahamtal Kasim, in a letter to the East African Standard, 16/9/1937.

2. President of the Dhow Association, in a letter to the East African Standard, 12/1/1940.

3. Three master builders were brought from Lamu in 1937.

4. Verbal evidence from a former dhow owner, Mwanza, February 1949

5. Brigadier-General Sir H. Osborne Mance, Report on the Co-ordination of Transport in Kenya, Uganda and the

6. Tanganyika Terrilor

6. Verbal Evidence, Mwanza, February 1949 
dhow with a 60 per cent. load factor with an annual mileage of 6,400 miles, would have costs varying per ton-mile capacity from 2.5 to 5 cents. ${ }^{1}$ It was further estimated that a dhow owner could make a bare living on rates of 4 cents per ton-mile, but it was noted that no dhow owner up till then had failed financially, unlike some of the lorry transporters. In this respect the important fact that the bulk of the dhow owners were not true transporters, but general merchants, should be remembered. Having first call upon their own dhows, they were able to control the market at the expense of non-dhow-owning merchants, who were compelled to import their goods by the more expensive railway services. Letters of complaint exist from other traders that dhow competition resulted in upset of the stability of transport rates and confused the market prices. Few dhow owners carried goods for other traders as they said little profit was made out of it. The position at Kisumu in 1936-37 is illustrative of the general position. One large firm accounted for 9,721 tons out of a total of 19,200 tons of goods carried in and out of Kisumu by dhow, 51 per cent. of the total dhow trade. Confining attention to the Kavirondo Gulf, out of 17 merchants trading in that area from Kisumu, only six owned dhows, nine out of the 14 dhows involved being owned by the firm referred to above, dhows varying in size from 18 to 85 tons. When it is realised that this particular firm combined the activities of general produce merchants and commission agents in Kisumu, Kampala, Mwanza, and Mombasa, with the ownership of two soap factories in Kisumu, and the agencies for two wheat and flour firms in Nairobi and for one of the Uganda sugar factories, it is easy to see how traffic to and from Kisumu, Musoma, Mwanza, Port Bell and Jinja could be influenced and controlled and the market made difficult for other traders.

\section{The Challenge of the Dhows}

The recrudescence of the dhow trade in the late 1920's coincided with a boom in trade and a period when the lake services provided by the railway administration were finding it difficult to move all the traffic which was forthcoming. By 1931 however, the extension of the two railway systems to their termini at Kampala and Mwanza had resulted in the diversion of much traffic from the lake to the railways. This change in traffic movement coincided with the depression of trade and resulted in such a reduction of lake traffic that the railway authorities were compelled to look for new fields of enterprise for their vessels. It was natural that they should look askance at the dhow trade which was clearly prospering and showed no sign of decrease, but on the other hand gave every indication of rapid expansion. The dhows were encroaching on the main traffic lanes, using costly facilities such as ports provided by the public services and benefiting at the expense of the railway from trade created by the latter. It is not surprising then that in 1931 the management of the Kenya and Uganda Railway began to pay attention to this new form of competition, and that from that time special records were kept of the dhow traffic. It was felt, nevertheless, that it was not feasible for the railway to compete for traffic carried by the dhows because of the great discrepancy in rates.

From 1931 to 1934, though careful records were kept, no further consideration seems to have been given to the question of capturing the dhow trade. In September 1934, again the view was expressed that competition with the dhows by lowering rates would involve fne railway of Kenya and Uganda in financial loss, and not only would lead to conflict with the Tanganyika Railways, but would undermine rail transport from Kampala. By the following year the detailed statistics that were accumulating began

1. Mance, op. cit., para. 102. 
to show the full extent of dhow competition, and a change in attitude towards the dhow traffic became clearly necessary. There was a natural reluctance on the part of the Kenya and Uganda Railways to establish a complete monopoly of traffic, and the view was expressed that the dhows formed a valuable feeder service to the main shipping routes, the dhows serving areas where the water was too shallow to allow even tugs and lighters to approach. The accumulating statistics showed that in large measure this was a false view. The dhows were operating as small units on the main traffic lanes, carrying 100 per cent. cargoes in both directions, leaving the residue of traffic for the larger and more expensive regular steamer services. In the northern part of the lake the dhow services clearly formed a dangerous competitor not only to the lake steamers, but also to the railway extension to Kampala. Because of its longer haulage this line, constructed at great cost and with much criticism, was very vulnerable to competition from cheaply operating craft transporting goods from Jinja and Port Bell to Kisumu, whence they were railed by the much shorter route. Sugar produced at the two large sugar factories close to Jinja was a case in point. The dilemma for the railway was a difficult one. To lower lake steamer rates would be to run the risk of diverting traffic from the railway to the railway steamers, and because of the low operating costs of the dhows rates, to be competitive, would have to be so greatly lowered that the financial structure of the railway would be damaged. The following figures show the extent of the competition.

TABLE 7

DHOW AND RAILWAY TONNAGES, 1933-1935

\begin{tabular}{cccccc}
\hline Year & & & & $\begin{array}{c}\text { Dhow Tommages Carried } \\
\text { on } \\
\text { Competitive Routes }\end{array}$ & $\begin{array}{c}\text { Tonmages Carried by Kenya } \\
\text { and Uganda Railways } \\
\text { and Harbours }\end{array}$ \\
\hline 1933 & $\ldots$ & $\ldots$ & $\ldots$ & 27,929 & 49,039 \\
1934 & $\ldots$ & $\ldots$ & $\ldots$ & 29,360 & 51,257 \\
1935 &. & $\ldots$ & $\ldots$ & 29,471 & 67,853 \\
\hline
\end{tabular}

The bulk of this dhow traffic was between the three ports of Kisumu, Jinja and Mwanza, with a smaller traffic in the Kavirondo Gulf and at Port Bell. The principal commodities carried were sugar, grains, cement, salt, rice, hides, simsim, potatoes, timber, soap, petrol, kerosene and ghee (clarified butter). From Jinja sugar was carried to Kisumu and Mwanza, imported goods and maize forming the return traffic from Kisumu, and rice from Mwanza. The Mwanza rice was largely grown on Ukerewe Island and along the shores of Speke Gulf, dhows collecting the paddy during the harvest season from ports which the tugs and lighters were unable to reach, but where a dhow could be beached. Later the same dhows conveyed the milled rice to the large Indian market in Uganda.

Dhow competition increased over the period 1936-38 directly through the rating differences existing between the two railways of East Africa. Since 1928, when the Mwanza-Tabora line was constructed, there had been considerable agitation on the part of the Tanganyika Railways for a greater share of the trade of the Tanganyika ports on Lake Victoria. A local agreement was made between the two General Managers of the railways which came into effect on January 1st, 1937, for five years. This agreement ruled that equal rates should apply between points in the Tanganyika area of the lake and the two ocean terminals, Mombasa and Dar-es-Salaam, traffic 
being allowed to take its natural course. Receipts were to be pooled and divided on a percentage basis agreed upon by the two systems. Both railways were to prevent re-booking from stations short of the coast in order to benefit from the cheaper rates that might be obtained over the internal system of one of the railways.

The agreement was unfortunately undermined through the adoption by the Kenya and Uganda Railways and Harbours of new and much lower rates on high-class goods carried over their own internal system. At the insistence of the Tanganyika Railways, who feared loss of traffic, these new and lower rates, by the terms of the agreement, were not applied to the ports in Tanganyika served by the Kenya and Uganda Railways and Harbours. Almost at once dhow traffic began to be a serious menace to both railway systems. It was clearly a very paying proposition to import goods by the new cheap Kenya and Uganda Railways and Harbours rates to lake points within the internal system of the railway, and then to ship them to Tanganyika ports on Lake Victoria by the use of cheaply operating craft. The reaction was swift and immediate. An existing committee of enquiry reported to the Tanganyika Chief Secretary that the dhows were a serious threat to the financial structure of the Tanganyika Railways. ${ }^{1}$ It declared that the Mwanza traffic and the traffic of the Mwanza hinterland as far as Shinyanga to the value of $£ 60,000$, was in danger of being lost, and that the railway which was already in a precarious financial position could not afford to lose this traffic. It was thought that the dhows had an important part to play in the development of the lake littoral, since serving small ports at a cheaper rate, they were able to forward the economic development of those areas. It was felt to be both unjust and uneconomic to eliminate the dhows, but restriction of their activities was felt to be urgent and desirable, particularly as indications were appearing that if the situation then prevailing were allowed to continue, the dhows would be replaced by cheaply operating highpowered motor craft.

This new development was viewed with equal alarm by the Kenya and Uganda Railways, who by their own action had created a situation likely to deprive them of the transport of the higher rated goods carried over the lake, and had encouraged further expansion of a traffic which threatened both the financial structure of the railway and of the railway craft.

High-class goods began to accumulate at Kisumu for Mwanza faster than the dhows could transport them, despite the lack of warehousing facilities, and the risk of damage in transit by dhow. The position was such that both railway authorities were constrained to consider legislation to restrict the dhow traffic. Road competition in other areas had made it clear that an Inland Transport Bill applicable to all three territories was desirable in the public interest. This form of legislation could be made applicable to lake traffic. Naturally the traders of the lake basin sought to justify their use of the dhows. One Chamber of Commerce protested that the failure of the Kenya and Uganda Railways to apply lower rates to the Tanganyika ports had forced them to use dhow traffic, and feeling amongst those traders who had no ready access to dhows ran high. On the western side of the lake at Bukoba, a dangerous port for dhows because of its exposed anchorage, Uganda sugar hitherto carried in the main by the railway craft, began to be moved by lorrigs. The use of lorry transport in conjunction with dhows made it clear to the railway authorities that piecemeal legislation for the lake would be fruitless. The Railway Advisory Council for the Tanganyika Railways was considering restrictive legislation on the dhow traffic between Kisumu and Musoma, and Kisumu and Mwanza, because of the threat to the Dar-es-Salaam traffic, but it was rightly pointed

1. Report of a Committee appointed to Inquire into the Question of Competition between Road Transport and Railway's and the possibility of co-ordinating the various forms of Transport in the Tanganyika Territory, Dar-es-Salaam, 1937, para. 34 et seq. 
out that such measures could not hope to prevent evasion of the law by the dhows beaching at unauthorised places and from there distributing goods by lorry, with resulting loss of customs revenue to the Tanganyika Government.

Despite vigorous protests from certain sections of the community, ${ }^{1}$ legislation in all three territories was passed late in 1937 or early in 1938 and this gave to constituted authority the power to control through the issue of licences, craft operating privately on the inland waters of East Africa. ${ }^{2}$ In all three areas licensing of craft was not to become operative until late in 1938 or in 1939.

In the early part of 1938 , the dhow owners appear to have made an effort loyally to keep a private agreement made amongst themselves not to compete with the railway in the carriage of high-class imported goods. This agreement was made on December 6th, 1937, by 37 dhow owners owning between them 81 dhows registered at Kisumu, Mwanza and Musoma, and federated as the Dhow Owners' Association of Mwanza. Nevertheless, despite this restriction they continued to thrive. Towards the end of the year signs became evident that the carriage of these types of goods was too lucrative a temptation to be resisted, and from July to the close of the year tonnages carried by the dhows increased sharply. At the end of 1938 the total tonnage carried by the dhows reached the figure of 36,771 tons, the highest ever attained, and represented a loss in revenue to the railways of $£ 38,848$.

In view of the fact that in 1938 the dhow traffic reached its peak it is suitable here to examine in some detail the character of the trade. Figure 8 shows in diagrammatic form the size and direction of flow of the dhow traffic in that year. There were principally three major centres of the dhow trade, Kisumu, Jinja and Mwanza, with minor centres at Port Bell, Musoma, the Kavirondo Gulf Ports and numerous unidentified ports in the Speke Gulf area. In the main the traffic lay between the first three mentioned ports. From Jinja the outward traffic was mainly sugar from the two Uganda factories. Out of a total of 9,880 tons of goods shipped by dhow from Jinja, 7,720 tons went to Kisumu and 2,145 tons to Mwanza, 7,297 tons being the amount of sugar shipped to Kisumu and beyond, and 1,166 tons that shipped to Mwanza.

The destination of the sugar shipped to Kisumu reveals clearly the competitive nature of the dhow traffic. The bulk of the sugar was railed down line, only 600 tons being kept for consumption in Kisumu, whilst 3,583 tons were railed from Kisumu to Nairobi alone. That this was serious competition with the railway is shown by comparison with the figures of sugar railed from the stations Jinja and Kawolo which served the two sugar factories in Uganda.

TABLE 8

SUGAR MOVEMENT FROM UGANDA TO KENYA, 1938

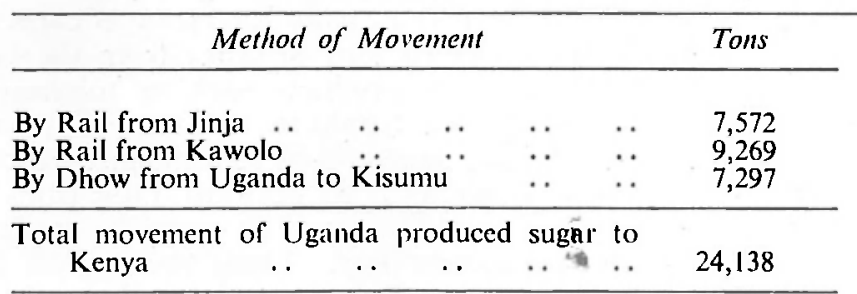

Between a quarter and a third of the sugardraffic was being lost to the railway in the first instance and then later was being railed from Kisumu

1. See the account of the debate on the Second Reading of the Transport Licensing Ordinance 1937 (Kenya) 2. The Inland Water Transport (Control) Ordinance Uganda, 9/12/1937. The Transport Licensing Ordinance
1937 (Kenya), 16/12/1937. The Inland Water Transport Ordinance (Tanganyika), 1938. 
in such a manner that it threatened the financial structure of the Uganda rail extension. From Mwanza the outward traffic was principally rice, the main consuming areas being Port Bell, 1,425 tons ; Kisumu, 802 tons ; and Jinja, 701 tons of rice.

From Kisumu the outward traffic originating at rail-head was more varied, but grain, chiefly maize and maize meal, together with locally manufactured soap and jagree, formed the bulk of the dhow cargoes. Out of a total of 2,130 tons shipped from Kisumu to Mwanza, 1,480 tons were grain (1,285 tons maize), 307 tons jagree, and 13 tons soap. To the Uganda ports of Jinja and Port Bell the dhows from Kisumu carried mainly grains, 742 tons to Jinja and 315 tons to Port Bell. The difference in quantities of grain imported into Jinja and Port Bell is probably a result of the closer position of Jinja to the two sugar factories, where the recruited labour, drawn mainly from tribes other than the Ganda and Soga, would be accustomed to a diet containing a heavy proportion of grain. To Musoma because of famine conditions there was in 1938 heavy movement of grain from Kisumu, some 3,000 tons being imported, together with 100 tons of soap.

The soap industry at Kisumu was largely in the hands of dhow owners. In 1938 they appear to have had a virtual monopoly in soap manufacture, and it was not until 1942 when crushing machinery for the extraction of cotton seed oil was installed at the Kakira sugar factory that any competition in this trade appeared. The basis of the Kisumu soap industry appears to have been coconut oil imported from the coast. The soap was wrapped in hessian and exported in bundles of $180 \mathrm{lbs}$. The distribution of the soap by dhows was mainly confined to the northern and eastern shores of Lake Victoria.

Of outstanding importance is the dhow traffic of the Speke Gulf. This traffic, though recorded by the railway authorities as Speke Gulf traffic, is really traffic originating from many small points along the entire southern shore of Lake Victoria. In 1938 the bulk of the trade originated in fact as well as in name along the shores of Speke Gulf and at the ports serving the great rice and cotton producing area of Ukerewe Island. Because of the very shallow nature of many of these ports and their lack of shelter, no tug and lighter service served the majority of them and their only outlet was through the dhow service. Here without question the dhows were operating legitimately and in the public interest. Without them it is doubtful whether the expansion in rice and cotton production along the shores of the Speke Gulf would have been so marked. Mwanza clearly functioned and, as figure 8 shows, still functions as a collecting centre for this area. In 1938 the in-traffic to Mwanza was 6,327 tons whilst the return traffic was 1,819 tons. Analysis of the content of this trade shows a clear division of the traffic. Primary products such as seed cotton, hides, cotton lint, rice, sisal poles, ghee, cassava, cotton seed, fruit, vegetables, maize, goats, sesame seed, beeswax, groundnuts, beans, honey, bananas, palm leaves, sugar cane, dried and fresh fish and firewood, are imported into Mwanza from the Gulf ports. Manufactured goods and secondary products such as tobacco, bicycles, milled rice, sugar, kerosene, petrol, furniture, coconut oil, soap, gunny bags, hoes, maize and wheat flour, jagree, salt, cement, piece goods, corrugated iron sheets, charcoal and lime form the outward traffic from Mwanza.

Of a similar nature, but on a smaller scate, was the traffic between Kisumu and Homa Bay and Kendu Bay. These two outlets for South Kavirondo and the Kisii area exported commodities such as ghee, simsim, hides, groundnuts, potatoes and above all, maize, with a return traffic of cotton cloth, rice, sugar, salt, jagree, kerosene, cigarettes, soap, cement, hoes and ploughs. The latter were being increasingly used by the Luo on the heavy black clay soil belt which fringes the lake shore and which is dominantly a groundnut and cotton producing area. 


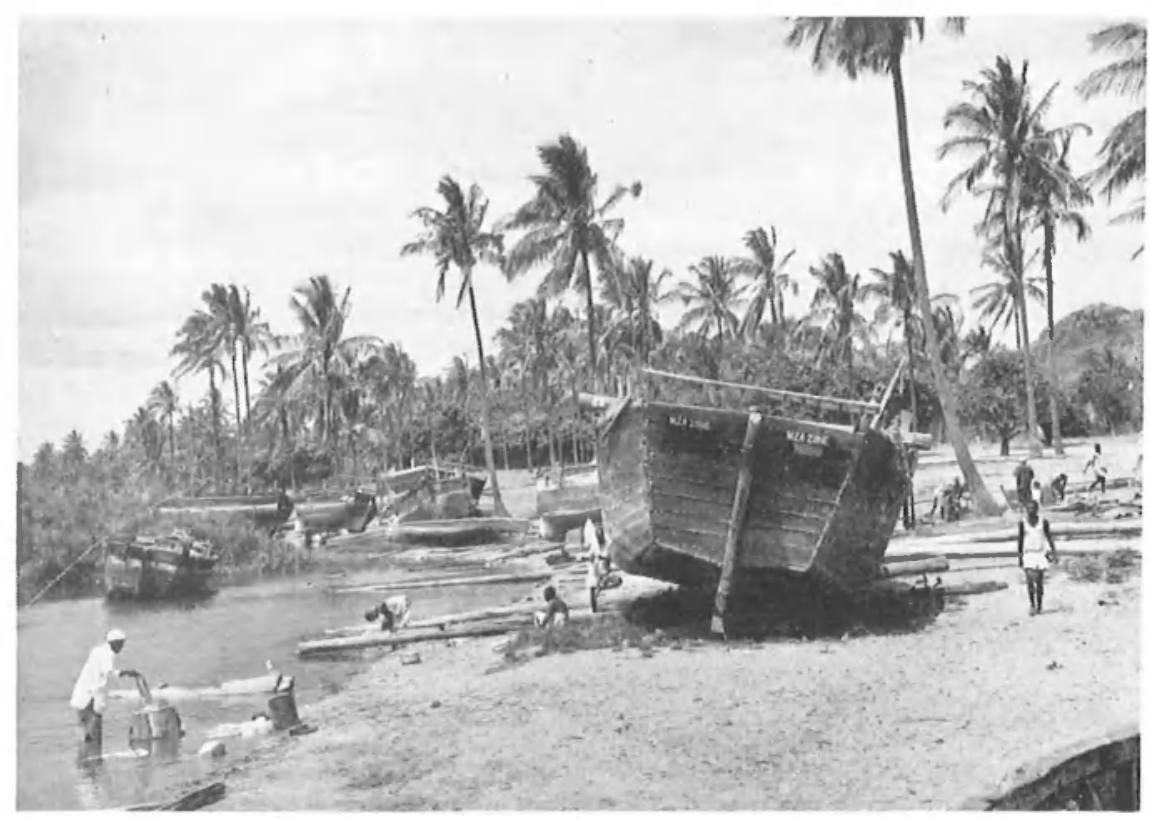

6 The dhow beach, Kirumba, Mwanza, Tanganyika. This beach, one and a half miles along the shore north of Mwanza, is the repairing centre for many of the Speke Gulf dhows. New dhows are also built here. The photograph shows beached dhows being repaired, a derelict dhow half submerged and the tall masts of eucalyptus wood lying on the sand. The coconut palms which give much of its charm to this beach are almost certainly relics of the Arabs who came from Lamu to build the dhows.

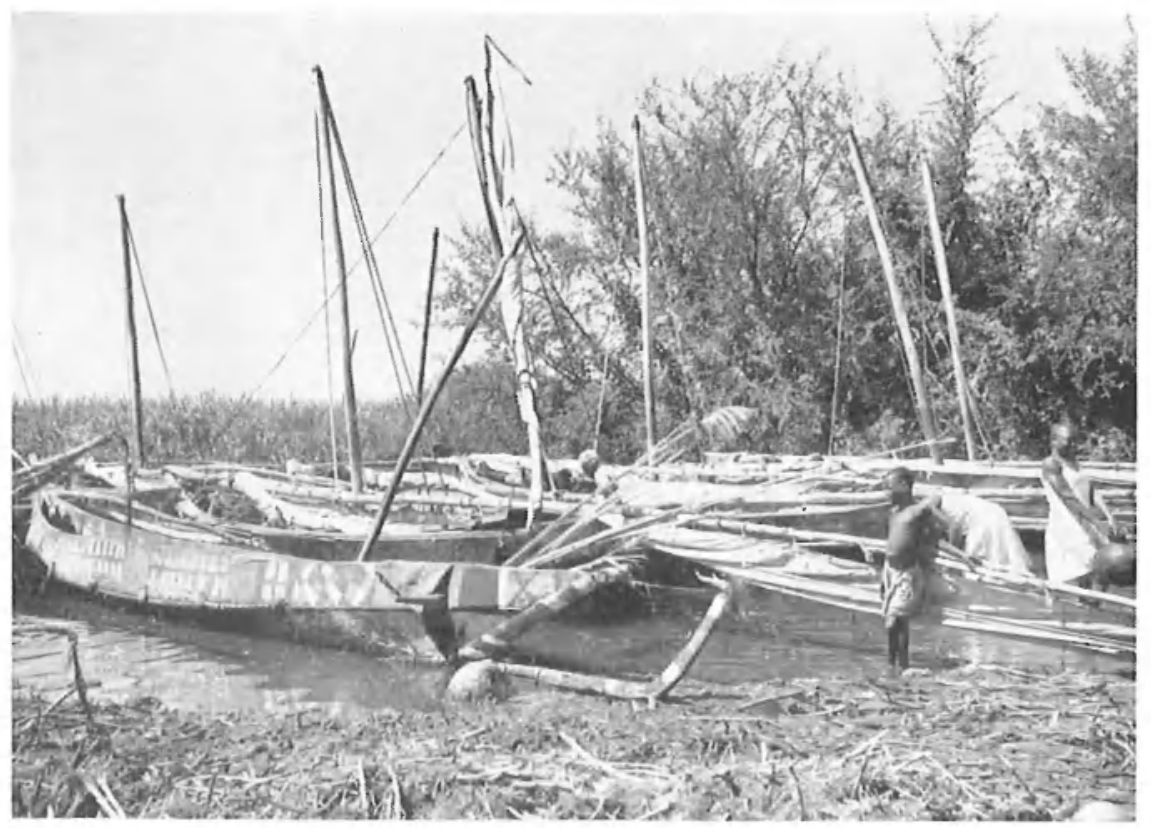

7 Fishing canoes, Asembo Bay, Central Nyanza, Kenya Colony. The gaily painted canoe is a good example of the sewn Sese Island type, with its prow and totem horns. 
The map of the dhow traffic in 1938, figure 8, does not show much traffic on the western side of the lake. This is a result of the very exposed nature of the coast which is rocky and bounded by high cliffs, unsheltered from the dominant onshore south-east winds. The principal centre of trade in this area, Bukoba, has a particularly exposed anchorage, and on the whole, dhows with their dependence upon the winds for their propulsion tended to give a wide berth to this region of the lake which has a bad reputation for dangerous storms, particularly towards the evening.

The map does not show another aspect of the dhow traffic, for which, naturally, no figures are available. There was undoubtedly a certain quantity of illegal traffic or smuggling over the Kenya/Uganda border into Tanganyika. Despite a Customs agreement between the two Customs services, sugar and salt remained commodities liable to importation taxes. It would appear that the method adopted was to consign the goods to Mohoru Bay, which is just within the Kenya boundary. From there the goods were carried in $60-\mathrm{lb}$. loads by porters or lorries for 10 to 11 miles to Shirati, just within Tanganyika, where they were then shipped by dhow to obscure and unwatched ports in Tanganyika. This method was also being increasingly applied to goods railed from the coast, using the new cheap through-rates of the Kenya and Uganda Railways which only applied to ports within Kenya and Uganda. This latter activity not only involved Tanganyika, Kenya and Uganda in a loss of railway revenue, but caused a loss of customs revenue to Tanganyika in that it prevented a correct division of tax receipts taken at Mombasa, since Tanganyika could not be credited with this traffic. Clearly the operation of the dhows along the eastern shore of Lake Victoria was a very serious financial problem for the two railways and their respective governments.

\section{The Victory over the Dhows}

In 1939 the various Transport Ordinances became operative and it was possible to prevent the inter-territorial movement of imported goods other than by the craft of the Kenya and Uganda Railways and Harbours. At more or less the same time the railway authorities indicated a change in rating policy with regard to competition with the dhows. Special rates for the transport of maize and maize meal were introduced between Kisumu Pier and Karungu, Mohoru Bay and Musoma. ${ }^{1}$

This direct attack upon one of the main commodities was followed in June 1939 by a more drastic one upon the vital sugar traffic. A recommendation by the Railway Advisory Council that

" sugar booked from Kisumu or any other ports on the east coast

of Lake Victoria be charged at the rate applicable from Jinja and that

the Jinja rate also apply to any such sugar as may be conveyed by road to another station and then consigned by rail"

was adopted on June 9th, 1939, by the High Commissioner. This drastic departure from ordinary rating procedure was defended on the grounds of protecting the earning power of the Kampala line, which had been built at the request of the Uganda Government. If competitive rates had been quoted between Jinja and Kisumu it was estimated that this would have caused a diversion from the railway and a loss of over $\$ 2,000$ a year. It was contended that the new policy would not inflict any damage upon the sugar industry which had, in any case, been able to expand greatly at an earlier period because of considerable reduction of the rates charged by the railway for the movement of sugar. In adopting the recommendation it was realised that the measure might secure all-rail traffic for the sugar, but that in any case even if dhows were used, the same revenue would be produced in the

1. Introduced 8 th June, 1938. Shs.: 5 per ton in 10 ton lots and over. 
case of all sugar moving beyond Kisumu. The sugar factories of Muhoroni and Miwani, close to Kisumu, were not included in the recommendation, as all their sugar moved down line towards Nairobi.

The effect of this measure was seen in a few weeks when one large firm sold its dhows by public auction. The advantage of the sugar factories near Kisumu in being nearer the Kenya markets, forced the factories at Jinja to lower their wholesale selling price by two shillings a bag. Within a month the dispatch of sugar by dhow from Jinja to Kisumu fell fiom approximately 742 tons to 72 tons per month, the latter amount being almost entirely for consumption in Kisumu.

This blow to the dhow trade was followed three months later by further attacks, aimed now at the Mwanza-Port Bell and Mwanza-Kisumu traffic, where the quotation of competitive rates could not involve diversion of traffic from the railway. On these routes therefore it was decided to quote low point-to-point rates for sugar and for country produce, i.e. grains, pulses, jagree, groundnuts, simsim, rice and paddy, the rates to include loading and unloading charges. ${ }^{1}$ These measures effectively attacked all the principal commodities carried by the dhows. The vital sugar traffic of the dhows was killed finally by the introduction of a through-rate for sugar from Jinja to stations along the Tanganyika Central Line. A further modification was to extend the country produce rates to Nansio, as much of the produce was taken by dhow direct from Ukerewe Island to Uganda and Kenya.

The effect of these measures was reflected in an increase in the intermediate port cargo carried on the railway craft, and was particularly noticeable at Port Bell. The total tonnage carried by the dhows in 1939 was only slightly below that of 1938 . This is explained by the fact that the railway rate changes came late in 1939 by which time most of the shipping contracts with the dhow owners had been completed. The full effect was felt in 1940. Tonnages carried by dhows fell from a total of 36,468 tons in 1939 to 27,306 tons in 1940 and by 1943 had fallen steadily to 9,151 tons. From 1941 onwards there was a steep rise in the traffic carried by railway craft between intermediate ports. This traffic which had been steady for years at about 5,000 to 6,000 tons, jumped progressively to 36,969 tons in 1946 and to 52,454 tons in 1952 . Some proportion of this increase in traffic is due to diversion of the dhow traffic to the railway craft.

Naturally this new policy of the railway aroused public controversy. ${ }^{2}$ Claims were put forward that the dhows were the "oldest industry on the lake", an argument that was refuted by statements that the dhows had arisen only with the expansion in the prosperity of the lake shores. This prosperity was due to facilities provided by the railway, and as the dhows had only lately trespassed on the main routes, the railway maintained that it was justified in safeguarding its financial position. In Tanganyika there was fear that elimination of the dhows would have an adverse effect upon prices within the territory, but the Kenya and Uganda Railways maintained that so long as their rates remained low, no hardship would accrue to Tanganyika, even if the dhow trade were partially destroyed. It was pointed out that if the dhow traffic were to be confined solely to the function of a feeder service to the railway, the work was insufficient to support the dhows and 2,000 people were threatened by unemployment. ${ }^{3}$ The railway authorities were not prepared to give way however, and the controversy finally died down and was forgotten by the general public who were more absorbed in the momentous events of that critical war year. ${ }^{4}$

Adopted 2/9/1939 to charge a special rate of Shs. 5 per ton between Kisumu and Musoma and Shs. 10 per On between Mwanza and Ugand

2. The East African press in January 1940 published correspondence from both parties on this issue, including a long letter in the East African Standard 12/1/1940 from the President of the Dhow Association.

3. A view endorsed by the Provincial Commissioner at Mwanza.

4. The Minules of the Railway Adrisory Council, Memo. No. A14/58/11 of 16/2/1940, make clear the determination of the authorities not to give way to the general clamour, and take the opportunity of formally atating the reason for their case. 
The final attack upon the dhows was the introduction of special cheap rates for soap carried from Kisumu to Jinja, Port Bell, Musoma and the Kavirondo Gulf ports. This measure could not hope to be wholly successful as the soap was manufactured by the dhow owners, but in 1941 the installation of crushing machinery at Kakira sugar mills for the manufacture of cotton-seed oil gave rise to a soap industry near Jinja producing cheaper and better soap than that at Kisumu, and resulted in the eclipse of the KisumuUganda soap trade.

\section{The Dhows in Eclipse}

From 1940 to the present day the history of the dhows can be quickly told. Dhow traffic declined rapidly and steadily, but has not become extinct. The war of 1939-45 put a strain on the transport services of Lake Victoria, which by 1942 brought about a lull in the rate war with the dhows. The same war however brought difficulties to the dhow owners in that materials for repairing the dhows and skilled workmen became unobtainable. Many dhows went out of commission and can be seen today as derelict hulks on Kirumba beach. The rice traffic was not killed immediately by the new rates because the rice merchants were dhow owners and preferred to earn something rather than nothing from their boats. They were still able to undercut the railway rates to a small degree and here speed of transport was not a material factor. For these reasons a small fraction of the old trade remained until later in the war when food restrictions imposed by the Tanganyika Government prevented the export of rice. In 1942 the dhows were still carrying 2,319 tons of maize flour from Kisumu to Jinja and from 3,000 to 4,000 tons of sugar in return, a traffic which has about it something of the elements of barter. The dhow trade declined steadily until in 1947 the dhows carried their smallest tonnage, 6,451 tons. Since then there has been a partial recovery, trade being stabilised at between 12,000 to 15,000 tons a year.

It is interesting to compare the map on figure 8 , which shows the total dhow traffic for 1951, with that previously described for 1938. The change is striking. In all quarters of the map the decline of trade is very evident. Traffic from Mwanza to the western side of the lake has all but ceased. War-time and post-war restrictions on the export of rice from Tanganyika, the competitive rates of the railway craft, and the exposed nature of the west coast have all combined to eliminate this once busy dhow traffic lane. In like manner the Jinja-Mwanza traffic has ceased.

For all practical purposes the map clearly shows that the carriage by dhows of sugar from Jinja, of maize from Kisumu, and of rice from Mwanza, a thriving industry in 1938, had ceased to exist in 1951. When examined in detail it is found that a profound change has come over the dhow traffic of Lake Victoria with the exception of that of the Speke Gulf-Mwanza traffic, which increased its size from 6,327 tons in 1938 to 9,797 tons in 1951 .

The dhows operating today are few in number and the largest of them is little above 11 tons in size. In the period 1944-46, 36 new dhows of an average capacity of eight tons were registered in Kenya. Significantly, few Indians today own dhows, and a considerable proportion of the dhows are owned by Africans. The traffic is essentially one serving small ports along the eastern shore of the lake, which are not tapped by the tug and lighter service. The trade is very largely one in firewood (a tonsiderable item in the Speke Gulf area), dried and fresh fish, fresh fruit, and a seasonal traffic in paddy and seed-cotton. A rough estimate in 1940 of the number of dhows in operation was about 40 , of an average capacity of eight tons and employing in all about 300 people, and approximately 100 karuas employing another 300 to 400 men. ${ }^{1}$

1. Verbal evidence given in Mwanza by an Indian who was formerly a dhow owner. A karua is a small fishing dhow of about two tons capacity. 
In the Speke Gulf area, a comparison of the traffic of 1951 with that of 1938 shows that the content of the trade has not altered very greatly, but tugs and lighters now move much of the seed cotton. The Speke Gulf has a wealth of fish, and fishing encampments, where the hauls are crudely dried, are to be found all along the shores of the south-eastern corner of Lake Victoria. Much of the traffic northwards along the east coast consists of small dhows taking dried fish to the Kavirondo area of Kenya.

From Musoma, the small dhows mainly carry dried fish and a considerable quantity of fresh fruit, particularly mangoes, the latter often being taken on board loose as ballast. The mangoes command a good price in the Kisumu area and further afield.

In the description of the dhow traffic in 1938 it was mentioned that smuggling was a characteristic of the dhow traffic along the east shore of Lake Victoria. Smuggling proved in the latter years of the war and the period following to be very lucrative. The Musoma area has developed into a large producing area of good quality ghee (clarified butter). Control restrictions in Tanganyika together with an acute shortage of ghee in Kenya and Uganda, particularly in the large urban populations, gave rise to a black market in ghee. It was estimated that in 1946 the profit on a smuggled tin of ghee was between 10 and 15 shillings if delivered at Mohoru Bay and 20 shillings if delivered at Karungu.

Today dhow traffic continues to serve the small ports of Mohoru Bay and Karungu, which are only served by the railway tug and lighter service and not by the large cargo-passenger boat service. The traffic from Karungu is almost exclusively in ghee, with a varied return traffic of small size in such items as sugar, salt, soap, ploughs, kerosene oil, cloth and sundries.

The Kavirondo Gulf traffic into and out of Kisumu is small and very varied in character. The figures returned as dhow figures also include merchandise brought daily by motor launch from Kendu Bay, the principal item of which is approximately 1,000 lbs. of fresh fish. In both maps it will be noted that the dhow traffic is solely with the southern shore of the gulf. Lack of a short good road and railway to Kisumu, such as those which serve the northern side, necessitates movement of the imports and exports of this agriculturally prosperous southern area by water. The railway tug service, though somewhat elastic, mainly runs twice weekly, and as a consequence there is scope for a small dhow trade from the area in such goods as ghee, maize, onions, hides, beans, and groundnuts, with a return traffic in timber, cement, salt, cloth, ploughs, sugar, petrol and sundries.

The dhow traffic today survives as a mere ghost of its former self. That it has survived at all is due to its function as a feeder service in those parts of the lake not served by railway craft, and this is, in the view of the Railway Authorities, its appropriate function. The ability of the dhows to enter small ports with extremely bad anchorages and exposed to sudden strong winds has preserved for them small areas free from competition. Because of their ability to "up anchor" and to put to sea quickly in a storm, the dhows can enter these small ports which are far too dangerous for the expensive and unwieldy tugs and barge trains. Undoubtedly the dhows fill a valuable function in the development of the more remote areas around the southern lake shore, where the short haulage and cost of operation would not pay to run a tug and lighter service. No one would question the wisdom of breaking the power of the dhows on the main traffic lanes of the lake, in the general interest of the public of the three territories, but it must be a matter of keen regret to all who love the picturesque that these large, stately, and beautiful craft have with few exceptions disappeared from the waters of Lake Victoria. 


\section{CHAPTER IV}

\section{THE TRADE OF LAKE VICTORIA AT THE PRESENT DAY}

\section{General Considerations}

Examination of published statistics shows a steady and rapid increase in the traffic carried by the railway craft since the end of the war in 1945. In 1945 the total tonnage carried was 122,364 tons and remained around this level for the following two years. In 1948 the effect of post-war development in East Africa together with the general recovery of trade was shown by a rise to 140,662 tons in the tonnage carried. By 1952 the figures had reached 197,868 tons. The rise is clearly the result of an increase in the traffic moving from the lake region through Kisumu to the extra-lacustrine areas. This increased output is not restricted to any one area, but, except for a marked rise at Mwanza, is spread evenly around the lake ports, giving the same general pattern of trade in both 1944 and 1952.

Examination of the map showing the total traffic for 1952 shows clearly the effect of the railways upon the present-day traffic of the lake. Kisumu is the chief railway terminus, 145,414 tons of goods passing through its docks in 1952 in contrast to the 32,840 tons moving through Mwanza. The importance of Kisumu becomes even more apparent when it is appreciated that with the figure quoted above, Kisumu handled 73 per cent. of the total of all the lake traffic carried in 1952. The two Lake Victoria Commodity Traffic maps for 1952 show the same strong flow of lake traffic to Kisumu and the Kenya and Uganda Railway system.

The restricted hinterland of the lake along its northern shore is revealed by the absence of any but the smallest ports between Kisumu and Port Bell. The bulk of the trade of this area, a richly productive one, is quite clearly handled by the railway. Away from the two main sections of the Kenya and Uganda Railways and their branch lines the size of ports increases rapidly. A good example of this fact is provided by the large traffic of the ports along the southern shore of the Kavirondo Gulf, in contrast with the conditions prevailing on the northern side of the gulf where the traffic is tapped by the Kisumu-Butere railway line. In like manner the importance of Bukakata, the third largest port on the lake, arises from the fact that no railway serves the rich agricultural area of Masaka District.

A geographical distinction reflected in the map is the previously mentioned diagonal division of the lake into a wetter and more prosperous north and west and a drier and less developed south and east. The prosperity of the former division is shown by the large size of the ports from Bukoba northwards to Port Bell and the frequency and size of the ports of the Kavirondo Gulf. On the other hand, with the notable exception of Mwanza, the region to the south and east has fewer and smaller ports. The sparsity of the population to the west of the Mwanza Gulf is shown by the small trade of the only two ports, Nungwe, serving the Geita gold mine and Geita District, and Buchenzi, which taps the small coastal belt. Diversion of the traffic of Sukumaland southwards from the lake by the Mwanza-Tabora railway is responsible for the smaller size of the taffic of Mwanza as compared with that of Kisumu. Along the whole of the eastern coast there are but three ports ; Musoma, the administrative centre of a very large district, and the small ports of Shirati and Mohoru Bay, these last two serving the area as yet largely undeveloped which lies to the north of the River Mara.

Consideration of the nature of the trade in certain commodities as 
shown by the two Lake Victoria Commodity Traffic maps for 1952 brings out clearly some of the regional differences around the lake. Compiled from records of individual consignments during 1952, the maps show the movement and tonnages of eight selected articles of commerce, major items of the traffic of the lake. Figure 10 deals with the trade in four articles of food, sugar, maize, coffee, and rice, produced around the lake shore and indicates the localisation of each food crop in one region peculiar to itself. Figure 11 shows the movement of timber, millets, cotton, and cotton-seed.

As the maps show, there is not very much coastal traffic between one port and another around Lake Victoria, and there is not a very active exchange of products between one region and another, despite the dissimilarity between north and west on the one hand and south and east on the other; but it is perhaps noteworthy that three of these maps, those for sugar, rice, and timber, show a small exchange of goods produced under the different circumstances prevailing in the individual marginal lands of Lake Victoria. This exchange is perhaps a forerunner of lacustrine trade which may expand considerably and help to bind the lands marginal to the lake into one distinctive region. As yet there is very little sign that the lake has proved to be a unifying influence ; rather has it acted as a dividing sea. Initial geographical advantages and disadvantages have led to great diversity which has been accentuated by the tendency of the products of the Lake Victoria zone to enter into the trade of extra-lacustrine areas rather than into inter-regional trade within the basin. The reason for an absence of coastal trade on a major scale probably lies in the fact that the majority of the population fringing the lake are peasants practising subsistence farming and with dietary prejudices which largely inhibit the exchange of the varying foods grown, sugar being the outstanding exception. The ubiquity of the Indian trader with a common economic and cultural outlook has accelerated the initial process of exchanging products. The rapid rise of a dhow trade, built mainly on traffic between one lake region and another, was the result of Indian enterprise and illustrates the unifying influence of the Indian trading community on the economic life of the Lake Victoria basin. The important trade in sugar, one that ranks high in lake trade, is a direct result of Indian enterprise.

\section{The Sugar Trade}

There are three centres of sugar production within the lake basin. Two of major importance are at Kawolo and Kakira lying respectively west and north-east of Jinja, and shipping their sugar at Port Bell. The third sugar producing factory sited at Miwani, 25 miles to the east of Kisumu, has had a chequered history and its sugar at present figures only to a small degree in the trade of the lake.

Something has already been said of the two Uganda factories in an earlier chapter. Both were encouraged to expand production during the war and their output has risen steadily. The larger of the two is at Kakira, but both factories have a modern plant. The factories work day and night throughout the year, except for a few weeks when the machinery is overhauled in May or early June, a period when the cane is in relatively short supply. The Uganda producers are favoured in that mature cane is available in almost all months of the year : it has been known for cane to be cut continuously for periods of 12 to 14 months. This natbrally enables the factories to work with comparatively low operating costs. It is very unusual to have conditions such as those of 1949 , when owing to prolonged drought both factories were idle for some months and sugar was imported from South Africa and Mauritius to supply the needs of East Africa.

In 1952 Uganda produced 55,180 tons of sugar, of which 34,950 tons were retained by the Protectorate for its own consumption. Uganda produces 
about two-thirds of the total East African production, and by inter-territorial negotiation each year a portion of the Uganda-produced sugar is allocated to Kenya and Tanganyika. This arrangement is necessary because the production of sugar within East Africa is insufficient to meet the demand and certain very limited dollar purchases of sugar from abroad have therefore to be made. In 1952 about 3,500 tons of Uganda-produced sugar thus allocated to Tanganyika was shipped across the lake to Tanganyika ports. Consumption of sugar within Uganda has risen from a monthly average of 1,075 tons in 1938 to 2,873 tons in 1952 . This rise reflects the growing demand for sugar by the African population and the increasing amounts of sugar made available to the people of Uganda by the inter-territorial allocations.

The plantation sugar area on the Kano Plains east of Kisumu occupies land which, though suitable for sugar cane, is very inferior to that of the Uganda estates. In recent years sugar production has fallen at the Miwani sugar mill. In addition to the supply from its own estate the factory receives cane from a number of small Indian growers. Difficulties between the factory and the growers over the renewal of contracts for the supply of cane, unstable weather conditions and a shortage of labour, resulted in much distress amongst the small growers in the period prior to 1948 . The difficulties in disposing of the crop forced them to convert their cane into an unpurified sugar known as jaggery, which is produced by boiling the juice of the cane in open pans. This jaggery and the factory-produced sugar do not in any sense compete seriously with Uganda sugar in the lake area.

Considering the character of the lake traffic in sugar as shown by the map the fact at once emerges that Uganda supplies the bulk of the sugar consumed in the various centres around the lake, and that the sugar traffic of Lake Victoria falls into two categories. First there is the transit traffic as shown by the movement to Bukakata. The port of Bukakata in 1952 imported 1,915 tons of sugar, compared with 804 tons in 1948, almost the whole of this sugar being destined for the markets of Masaka District and southwestern Uganda. The rise in the transit traffic of Bukakata contrasts with a change in the character of the sugar traffic to Mwanza. In 1948 the transit traffic in sugar through the port of Mwanza was much the strongest line of movement; 3,000 tons of Uganda sugar were railed from Mwanza to inland Tanganyika centres. In 1952 this amount had fallen to 781 tons, the bulk of the 2,832 tons of sugar shipped to Mwanza being either retained there or redistributed to smaller centres such as Nungwe. Nansio, Buchenzi and Musoma. This is an example of the second form of traffic where sugar is distributed to various centres around the lake, whence secondary distribution of sugar may take place to the small settlements. Further examples of secondary distribution of sugar are to be seen in the small movements of sugar from Musoma to Shirati, from Kisumu to the southern ports of the Kavirondo Gulf and from Entebbe to the small ports of the Sese Islands.

The map clearly shows the restricted movement of sugar from the Miwani factory into the lake basin. In 1952 Kisumu Town received 2,685 tons of sugar by rail from Miwani, the bulk of which was consumed within the town and perhaps some distributed by road and rail to nearby centres to the north of the Kavirondo Gulf. Only 67 tons were shipped from Kisumu Pier, the whole of this amount going to the ports along the southern shores of the Kavirondo Gulf.

In Uganda in 1952 no shortages of sugar were rechorted from the various districts, but the average quantity available per head per month for the Protectorate as a whole was only $1.29 \mathrm{lbs}$., the range varying from $3.1 \mathrm{lbs}$. in the relatively wealthy Mengo District to $0.09 \mathrm{lbs}$. in Rigezi. These figures together with the very small imports of sugar into the thickly populated districts of South Nyanza, North Mara and Musoma, suggest that despite the African's love of sugar, it does not as yet bulk largely in his diet, a reflection no doubt of his poor financial resources. 
An indication that the production of the Uganda factories is insufficient to meet the sugar demands of the population within the lake basin is given by the importation of 760 tons of sugar through Mwanza from Dar-esSalaam, 152 tons going to Bukoba, 171 tons to Musoma and 437 tons to Mwanza. From the point of view of meeting the demands of East Africa as a whole, and increased demands in the future within the lake basin itself, there is need for much greater sugar production, and schemes are afoot to increase the number of sugar plantations. In Bukoba District a pilot sugar estate was started in 1950 on 70 acres of peaty soil near the lake, and in 1952 a likely area for a third estate in Uganda was selected, with a possibility of its development being fostered financially by Government.

\section{The Maize Trade}

The map of maize traffic serves to emphasise two points. First is the importance of maize cultivation on the rich, fertile, well watered soils of South Nyanza and to a lesser extent on those of North Mara. Four ports handle the maize traffic which originates in the highland area of Kisii and North Mara, the largest traffic passing through Kendu Bay. Daily to this port lorries bring the sacks of maize from the buying posts around Kisii, 20 miles to the south. To store the grain the Maize Control Board has built large sheds near the pier.

Secondly, the diversion of the traffic of North Nyanza and of Mengo and Busoga Districts from the lake to the railway lines and to the roads is clear. The map shows none of the tremendous movement of maize which is a feature of the commercial agriculture of these districts; no port on the northern and north-western shores of the lake handles any maize. The establishment of the Grain Conditioning Plant at Jinja enables very large stocks of conditioned maize to be stored to cover requirements between harvests and the possibility of a short crop. Some of the Uganda crop is stored in Kenya, some 70,000 bags of conditioned maize being held in 1953. The size of the Uganda production is shown by the returns for 1953, when Government purchases of maize in the four districts of Mengo, Busoga, Masaka, and Kigezi, amounted to $1,397,908$ bags, some 280,000 acres being planted in Buganda and Busoga alone. Because of the state of world market prices it does not pay to export Uganda maize abroad. Unless serious shortages in Kenya and Tanganyika cause the absorption of Uganda's surplus crop there is therefore the distinct danger of over-production unless the acreage planted is reduced.

In Kenya the purchase and marketing of maize is controlled by ordinance, the controlling body, Maize Control, being responsible to, and subject to the general directions of the Member for Agriculture and Natural Resources. Maize prices are fixed by the Government, and the Maize Control has the task of buying and storing maize until it is required for consumption, and of ensuring its correct distribution. The Maize Controller, acting as the Agent for the East African Cereals Pool, is responsible for meeting the needs of the other territories in East Africa and the Military Authorities. ${ }^{1}$ To do this he is responsible for storing any surplus of maize from the other territories and maintaining an emergency reserve vąrying between 250,000 and 500,000 bags.

In Nyanza Province, the Nyanza Marketing Organisation, a part of the Maize and Produce Control system, controls the sale of maize by African growers. All maize surplus to the grower's own needs must be sold in the nearest market to traders licensed by the District Commissioner, traders who must in turn sell the maize through the Maize Control. The maize

1. The East African Cereals Pool was wound up in July 1952. 
millers are also registered and hold stocks of maize for the Control. This very tight control of maize and maize flour enables stocks to be accumulated and maize flour to be sent from central depots to those areas where food shortages make supplies necessary. This control is responsible for the direction which the maize takes on leaving the South Nyanza ports. In 1952 the Maize Control had erected and was the owner of storage capable of holding 900,000 bags of maize and was constructing a storage for a further 460,000 bags. The policy was to store the grain at railheads in the various producing areas, using also stores in Nairobi capable of holding 250,000 bags. A Grain Conditioning Plant in Nairobi had been bought and another erected at Kisumu. The policy was further to avoid straining rail services by movement of grain immediately after the harvest and double movements of grain by rail, storing the bulk of the crop instead in the producing areas until such time as the grain was required. This controlled movement is shown by the map, the whole of the maize from Mohoru Bay, Homa Bay and Kendu Bay being consigned to centres along the railway line, such as Nairobi, Nakuru and Kisumu.

The year 1952 was a difficult one climatically in the Nyanza Province, rainfall above the average in the earlier part of the year being followed by drought in the last months, and this resulted in a reduction of the surplus maize crop from the 1951 planting. Local food shortages, particularly amongst the Luo on the Kano Plains, resulted in much local movement of maize. In this respect it is noteworthy that some 16,000 tons were exported from South Nyanza ports, despite the poor weather conditions. An indication of the expansion of maize cultivation is given by comparing this figure with that of the year 1946-47, an average climatic year, when 12,975 tons were estimated to be available.

Maize movements from Shirati and Musoma were all to Mwanza and reflect the character of Mwanza as a distributing centre, as is shown by the movement of 433 tons of maize from Mwanza to Bukoba, and 60 tons to Nungwe and three tons to Mwanyire. Maize production in North Mara has grown steadily in the last 10 years and has brought about a revival in the trade of Shirati. In 1948753 tons of maize were moved from Shirati to Mwanza, and this had increased to 974 tons in 1952. The North Mara area is an important source of maize for the mines in the Musoma District. The Musoma District at times verges on famine and the North Mara area is then looked to for help.

\section{The Coffee Trade}

The map of the coffee traffic clearly demonstrates the division of the lake zone into a humid half to the north and west and a drier one to the south and east. Coffee flourishes only in wet conditions and is affected by drought. "Robusta " coffee prefers hot, wet conditions but " arabica "coffee succeeds where temperatures are cooler than those usually found around the northern and western shores of the lake.

The position of Bukakata as the only outlet for a large and rich hinterland is strikingly shown by the volume of coffee traffic issuing from that port. Through Bukakata in 1952 there passed the largest export tonnage in any one single commodity handled on Lake Victoria, 10,711 tons of coffee, the bulk of it " robusta". Most of this coffee was grown on African plots in eastern Masaka, and hulled and sacked in the vicinity of Masaka township. All of it moved through Kisumu to Mombasa for export.

Statistics of coffee exports from Uganda show the notable development of the Bukakata area, the coffee exports of this port jumping from 54 tons in 1922 to 10,711 tons in 1952, more than a quarter of the total Uganda export. In 1952 Uganda exported some 39,450 tons of coffee, worth $£ 12,345,000$, 
of which more than half was shipped across the lake to Kisumu.

In Chapter One the conditions under which Bukoba coffee is produced were outlined. The direction taken by Bukoba coffee is, like that of all other coffee produced around Lake Victoria, through Kisumu to Mombasa or the Nairobi Coffee Market. Long-standing custom, deriving from the days when Kisumu was the only outlet from the lake, combined with the superior facilities for handling coffee in Kenya, confines the coffee trade to the Kenya and Uganda section of the East African Railways. It was an old grievance of the Tanganyika section that this valuable coffee traffic was not carried over their line, but until port and marketing facilities are improved at Dar-es-Salaam it is unlikely that any change in direction will occur. In 1952 Bukoba shipped 9,136 tons, all of it moving direct to Mombasa.

Kibanga serves a European-owned coffee plantation area in its vicinity, whilst much of the coffee exported through Port Bell derives from the very fertile county of Kiagwe between Jinja and Port Bell, where there are several coffee plantations on about 13.6 square miles of alienated land. Hera as elsewhere in Buganda, African grown "robusta" coffee bulks largely in the coffee exports. In 1952 Port Bell exported 9,357 tons of coffee, the whole consigned, as with the case of the Bukoba crop, to Mombasa for export overseas.

The return of the population to the Sese Islands has brought about a small-scale revival of the very old export of coffee to the mainland, whence after further preparation it is re-shipped from Port Bell.

The coffee exported from Kendu Bay is of the "arabica" variety, grown under the cooler conditions of the Kisii Highlands, where 472 acres have been planted, of which only 205 acres in 1952 were in bearing. The acreage planted has increased considerably, rising from a total of 196.78 acres in 1947 to 472 acres in 1952, 102 acres being planted in 1952. The bulk of the coffee is grown in the South Nyaribari location, in the neighbourhood of Kisii town. A coffee union of 12 primary co-operative societies operated 12 pulping stations, producing 26.5 tons of parchment coffee and 12.7 tons of dried cherry, " buni ", valued at $£ 6,982$. Preparation of the coffee needs closer supervision, but despite this, production and quality of the crop have improved and increased from three tons in 1938 to 39 tons in 1952.

The coffee shipped from the port of Nyamirembe is "arabica" coffee grown in Ngara District, where it is the main cash crop. The industry is of recent origin and production has expanded from 70 tons in 1949 to 720 tons in 1952. This coffee, like that from Bukoba, was dispatched after grading to Mombasa where it was sold by auction. The British Ministry of Food bought part of the 1951-52 crop at a contract price, but the contract was not renewed after June 1952, and the coffee is now sold on the open market.

\section{The Rice Trade}

Of the three crops so far mentioned, sugar, maize, and coffee, considerable portions pass as exports beyond the conftnes of the Lake Victoria zone, and this is also true of the fourth food crop,rice, the traffic in which is mapped on figure 10. Rice is even more localised in its production than the other crops, for with the exception of the two vey small centres of Musoma and Kisumu, all the rice entering into the commerce of the lake comes from Mwanza. It is grown along the shores of the Speke Gulf in the Nyanza Federation of Mwanza District, on Ukerewe and Ukara Islands, on the Majita Peninsula in Musoma District and in central Kwimba. Rice was grown before the advent of the Europeans, but its cultivation has expanded considerably under Government encouragement. The production of rice 
fluctuates greatly with rainfall, especially in those areas where the rice pans depend solely on rainfall, rather than, as is the case in the older rice growing areas, on water from the lake or from seepages into basins. The seed is usually sown in November or early December in nursery beds where the soil is moist, or where suitable seepages of water are found. The bed is well prepared, and after sowing, the seed is protected from birds by a grass mulch or a cover of thorns. When the main rains begin the rice pan is dug to a great depth and, if water is plentiful, the ground is puddled and then the young rice is planted singly by hand. The crop is harvested in June and July by cutting off the heads by hand.

The Majita peninsula, formerly a very good rice area, is rapidly degenerating. Over-cultivation, leading to excessive soil erosion, has caused many seepage areas to dry up, and rice production is becoming more and more confined to the lake shore.

Many of the small areas of rice cultivation along the Speke Gulf are tapped by dhows and the rice taken to mills at Mwanza. An exchange traffic in rice and sugar between Mwanza and Uganda, formerly carried by the dhows, still exists today, though the dhow traffic is dead, and in the case of rice the trade is much reduced in volume.

The Indian populations of Uganda and Kenya are the main consumers of the rice exported from Tanganyika, for rice does not figure to any large extent in the diet of the African. Rice from Mwanza finds its way to the large urban centres, where considerable Indian populations create a demand.

The rice trade of Mwanza has from early times been considerable. In 1913-14 527 tons were shipped to Kisumu, and although production fell during the years of the war of 1914-18, by 1920-21 1,201 tons of Mwanza rice were again moved over the Uganda Railway from Kisumu. In 1935, 1,302 tons were imported into Uganda, a figure which rose to 2,270 tons in 1938. Exports of rice from Mwanza have fluctuated considerably in recent years. A series of bad droughts in 1943 and 1944, and lack of rain at the right time in 1945 and 1946 resulted in a marked decline in the export of rice, culminating in a complete ban by the Government of Tanganyika on its movement from the territory. For some years there has been a tendency for rice to be consumed by the growers with a consequent fall in the amount offered for sale. In 1939 Mwanza exported to Kenya and Uganda 4,405 tons of rice valued at $£ 45,155$, the figure rising to 8,979 tons valued at $£ 102,318$ in 1942. The result of four bad climatic years was to reduce the total production of the whole Lake Province of Tanganyika to 2,260 tons in 1946 and in that year only 1.5 tons valued at $£ 26$ were shipped to Kenya and Uganda. Exports were resumed in 1947 but not on the scale of the early war years. In 1952 approximately 2,900 tons of rice from the Lake Province of Tanganyika were shipped across the lake to Kenya and Uganda, the recorded tonnage of paddy marketed by growers in that province being 5,185 tons.

The rice shipped from Kisumu is a tiny fraction of that grown in North and Central Nyanza. In 1952 heavy rains in North Nyanza made ploughing of the swamps impossible, with a consequent reduction in the acreage for Nyanza Province from 10,100 acres in 1951 to 5,000 acres. There was, however, a further development in the growing of transplanted, irrigated rice on the Kano Plains. In 1952 the Nyanza Province marketed some 1,463 tons of rice valued at $£ 21,847$. South Nyanza grows very little rice and a certain amount is imported from Kisumu through Kendu Bay to supply consumer demands.

\section{The Timber Trade}

On figure 11, the first map shows intricate movements of timber, but the salient point emerges that there is one timber producing belt in the Lake Victoria zone. Between Bukoba and Entebbe, sited on the low swampy 
ground fringing the lake, covering the islands, and filling much of the lower valley of the River Kagera, are patches of thick forest. Exploitation of these forests was greatly accelerated during the period 1939-45 when large quantities of timber were needed for the armies in Africa and the Middle East. The serious inroads made on the more accessible of the forest areas as a result of uncontrolled and indiscriminate cutting during the absence of most of the forestry staff on active service make it imperative that new areas should be exploited and that methods should be adopted to extract the timber from the more inaccessible forests in the interior of the Uganda Protectorate. Only one major area around the lake shore, southern Busoga, remains as yet unexploited ; careful opening up of this zone, closed for many years because of sleeping sickness, would yield a valuable supply of good timber. The demand for timber continues to be pressing and though production has fallen at some of the timber producing points, the commodity still bulks greatly in the traffic of the Kenya and Uganda section of the East African Railways. The timber is transported by the tugs and lighters of the railway administration, as the two large cargo-passenger boats do not call at the majority of the timber ports.

The timbar belt includes two sources of supply, the riverine and other mainland forests, and secondly, the forests of the islands of Kome North, Zinga, and Bugala. The mainland source, as the ports of Sango Bay, Kyaka Ferry, and Bukoba show, is principally in the territory overlapping the Uganda-Tanganyika border. In Uganda there are the Tero and Malabigambo Forests served by Sango Bay, and in Tanganyika the Nyakabadzi and Bushenya Forests with outlets at Kyaka Ferry and Bukoba. Bukakata serves a belt of forest in the Masaka-Bukakata area.

As would be expected, the timber from this north-west coastal belt takes three routes, to Uganda, to Kenya, and to Tanganyika. The quantities of timber consigned to Uganda and Kenya are roughly comparable, whilst somewhat smaller amounts are exported through Mwanza. The bulk of the timber sent to Kenya in 1952 went direct to Mombasa for export abroad, but in previous years large consignments have been sent to the big timber yards in Nairobi, whilst that sent to Uganda moves by rail to storage yards at Kampala, Jinja and, in northern Busoga, Nsinze.

There is a second stream of timber traffic which enters the lake basin at Kisumu, timber moving from the forests on the Mau Highlands to the various ports along the eastern and southern shores of Lake Victoria, Mwanza receiving the major portion of this traffic. Stations such as Molo, Elburgon, Londiani and Timboroa are the chief sources of the timber, though some comes from timber yards in Nakuru and Nairobi. Some of the timber, such as that entering Musoma, is for use in the mines, but the bulk of the timber is for general purposes.

\section{The Millets Trade}

The map showing movements of millets across Lake Victoria is compiled from consignment statistics which refer to a variety of grains, namely Sorghums, Bulrush Millet, Finger Millet and Foxtąil Millet. It is not possible to distinguish between the various forms.

The map shows one major source of supply, Sukumaland in the Lake Province of Tanganyika, with minor sources in Ukerewe Island, Musoma District, South Nyanza, Bukoba District and south-western Uganda.

In Sukumaland, a densely populated area, the staple food crops are sorghum, bulrush millet and maize. Sorghum is the staple food of central and southern Sukumaland. It grows well on a wide variety of soils, and yields heavily on the "mbuga " soils which are widespread. It is, however, liable to fail on the heavy soils in very wet years and to fail on the light soils in 
very dry years. In central Sukumaland in 1952, when excessive rains occurred, flooding of the fields was responsible for lower acreages planted and lower yields. In these thickly populated areas approximately two acres of sorghum are planted by each grower. Varieties of sorghum which store well form the main reserves of food for the people in years of poor harvest. Sorghum is susceptible to considerable loss caused by the parasitic weed Striga, particularly when cultivated on poor soils. Bulrush Millet (Pennisetum) is not so affected and is an important crop in the poor soil areas of Musoma District. It is the staple grain of north Sukumaland and in the islands of Ukara and Ukerewe.

Finger Millet (Eleusine) is an important crop in many parts of Musoma District, especially the higher and wetter areas. This is the case in the Zanaki area, and in the Kuria Federation of North Mara and the Kisii area of South Nyanza finger millet is an important grain crop together with maize. In South Nyanza sorghum is grown on the heavy and drier lake shore soils.

In Uganda sorghum is an important native food crop, and is pre-eminent in Kigezi. None of the Kigezi crop, however, enters into lake trade, as a strict ban on the export of food from the district has been in force since 1943. Finger millet is also widespread and is an important crop in Ankole. Only very small acreages ol bulrush millet are grown in the whole Protectorate. In 1952 district acreages of sorghum planted were 10,327 in Ankole, 168,338 in Kigezi, and 3,223 in Masaka. Acreages of finger millet planted in 1952 for the same districts were 31,333 for Ankole, 53,450 for Kigezi, and 936 for Masaka. The reduced acreages of both crops in Masaka District bring out the replacement of millets by plantains as the chief source of food.

In Bukoba District finger millet is second in importance only to plantains and is of great importance in the drier areas of the district. In the wetter parts of Bukoba District it is possible to reap two crops a year, sowing in September and October, reaping in January and February, with further sowings in April followed by a second harvest in July and August.

The movement of sorghums and millets by lake services shows a strong flow through Kisumu to the Kenya and Uganda Railways line. Of the 3,480 tons shipped from Mwanza, 2,248 were sent direct to Kilindini harbour for overseas shipment, 711 tons to Nairobi for sale or storage, and about 250 tons to Jinja and Kampala. Mohoru Bay and Homa Bay showed movements similar to each other. Of the 481 tons shipped from Mohoru Bay, mainly eleusine, 152 tons went to Nairobi, 40 tons to Nakuru, 53 tons to Kilindini Harbour, and 120 tons to Kisumu. Bukoba and Bukakata, though handling only small quantities of grain, presumably grain surplus to the needs of the population, both showed movements to Kilindini Harbour and to the Northern and Tanga Provinces of Tanganyika. Bukoba handling 322 tons, sent 180 tons to Kilindini Harbour, 40 tons to Tanga, 30 tons to Korogwe, and 50 tons to Dar-es-Salaam. In 1952 Uganda exported overseas 154 tons of millet, of which 23 tons passed through Bukakata. The bulk of the crop passing through Bukakata is finger millet grown in Ankole. The quantity of millet shipped from Bukakata in 1952, 246 tons, was greatly in excess of the tonnage marketed in Ankole and Masaka Districts, and therefore the shipments must include part of the 1951 millet crop which was large.

\section{The Cotton Trade}

The map of cotton traffic on Lake Victoria shows the small extent to which lake transport is now used for the movement of Uganda-grown cotton. In 1952 little more than 4,000 tons of cotton, in 400-lb. bales, was shipped to Kisumu, although the total amount of cotton lint exported in that year from Uganda was 67,911 tons. Virtually all the main cotton growing areas of Uganda now rail their cotton direct to Mombasa, and the lake boats 
carry only the cotton from those areas south of Kampala which are not served by a railway line. Bukakata, Katebo, Buwaya and Entebbe, together serve the southern continuation of the cotton belt which stretches through the Eastern Province of Uganda into southern Buganda. The cotton belt also extends through the southern portion of Mbale District into that part of Northern and Central Nyanza west of the Nzoia River which is served by the two small ports of Sio and Mjanji. Except in the area west of the Nzoia River, cotton production has declined steadily in the Nyanza Province of Kenya. In 1937 Kendu Bay exported 1,858 bales of cotton lint, but by 1948 the figure had fallen to 418 , and the unpopularity of cotton as a crop in South Nyanza had been fully shown. The reasons for the decline there and in the rest of the Nyanza Province are not hard to find. Food production drives during the war years combined with high prices for food crops resulted in greater attention being given to the growing of maize, rice and groundnuts, instead of the more exacting crop of cotton. Lack of Government direction to grow cotton and declining yields from areas of cotton cultivation also contributed to the marked fall in the amount of lint offered to ginneries. The decline in cotton cultivation in this part of the lake zone resulted in the recommendation of a Nyanza Cotton Committee in 1948 that several ginneries, including either Homa Bay or Kendu Bay, should be closed, and that the areas growing cotton should be drastically restricted by closing numerous buying posts. This decision was influenced by the need to check cotton growing on some areas of easily eroded land, and to concentrate the growing in areas where ginneries could be assured of economic supplies.

Cotton is interesting as a crop which contributes to trade both in the north-western and in the south-eastern sections of the lake zone, for its cultivation is also of importance in the Lake Province of Tanganyika. In some parts of the province a very late start with cotton growing on any considerable scale was made, a fact which is true of the Musoma District. Though cotton growing began in 1924-25 the cotton had to be shipped to Mwanza for ginning and it was not until a ginnery was established at Mugango in 1936 that any real encouragement was given to cultivation of the crop. The principal cotton growing area in the district is along the coast south of Musoma, principally in the Chiefdom of Mugango where there is a dense population.

In the Lake Province of Tanganyika cotton growing is well established in the areas close to the lake shore which are known to produce good yields, and it competes for the soil with rice and groundnuts, the other main cash crops. The growth of cotton is encouraged by the Government, as the drought resisting properties of the plant ensure an income for the peasant cultivator when his rice and groundnut crop fail. The cotton is planted in November and December with the beginning of the rains, picking begins in June and July and the ginning season lasts from July to October. As a result, cotton is available for export at a time when the main Uganda crop has been transported, and the movement of cotton from the south of the lake over the Kisumu line does not occasion any traffic congestion. In the Lake Province many crops are cultivated by ridging the soil into broad-based low ridges, a highly commendable practice which serves equally to drain waterlogged soils and to absorb moisture in dry areas by expesing a greater area to the rain. This wholly admirable practice was native to the people of Sukumaland and Nyamwezi. If placed along, the contours the ridges prevent soil erosion and under encouragement from the Department of Agriculture the peasants now add transverse ridges to make a tie at short intervals. The shallow basin which results proves a most valuable method of storing water in dry areas. On Ukerewe Island, where increasing amounts of cotton are being grown at the cost of food production, the recent introduction of tie-ridging has had the result of greatly increasing the yield of cotton lint. 
Most of the cotton is now moved by the tug and lighter service which serves the small ports around the shores of the Speke Gulf, together with Buchenzi west of Mwanza, and Musoma, but small dhows still carry the raw cotton, at times unsacked, from many small centres to the ginneries. Dhows discharging at the private piers of ginneries sited on the lake shore are still a common sight around Mwanza. In 1952 the cotton crop of Tanganyika was a record one, 13,900 tons being produced, of which the bulk, 12,857 tons, was from the Lake Province. Roughly one-third of this crop, 4,626 tons, was shipped to Kisumu consigned to Kilindini Harbour. The rest of the crop was railed by the Tabora line to Dar-es-Salaam. The greatly increased production of cotton in 1952 was due in part to the raised prices paid to producers, in part to good weather conditions, and in part to early planting and better cultivation as a result of encouragement by officials of the Agricultural Department.

Some 10,000 bales of cotton lint from the Lake Province were sold by auction in the free market by the Uganda Lint Marketing Board, Kampala, the remainder of the crop having been purchased by the Raw Cotton Commissioner. In Uganda, under a bulk agreement, the United Kingdom Raw Cotton Commission and the Government of India purchased 75,591 bales and 150,677 bales respectively, whilst approximately 153,000 bales were sold in the free market auctions in Kampala. The movement of the cotton from the lake ports of Tanganyika exclusively through Kisumu would appear to be solely the result of using the route which at that time was most convenient for the railway authorities, and is possibly an example of the advantages to be had from a unified East African railway system. With the exception of the port of Mwanza, the map accurately shows the baled cotton lint exported from the areas of the Lake Province which are not served by railway lines, but the position is comparable with that in Uganda in that the map does not show the sum total of cotton grown in the region adjacent to the lake, since the Mwanza-Tabora railway diverts a proportion of the crop to Dar-esSalaam.

\section{The Cotton-Seed Trade}

Cotton-seed, the by-product of the cotton-ginning industry, naturally has the same places of origin as the lint. When the seed is crushed the oil extracted from it is used principally for food, though some of it is used locally in East Africa for soap manufacture ; the cake provides a valuable cattle food. A useful practice is the application of cotton-seed to coffee as manure, but this does not occur on a large scale.

Owing to its bulky nature, cotton-seed can be profitably railed only if transport costs are low and a reasonable price can be obtained for its sale. In the past too, the Kenya and Uganda Railways have experienced difficulty in moving large quantities of the seed, because of the demands upon rolling stock by other more immediately essential commodities, such as maize. The problem is complicated because plague is endemic in the lake area and cotton-seed can be kept only in rat-proof stores, and it is in any case inadvisable that cotton-seed should be stored for any long period.

A comparison of the maps of cotton lint and cotion-seed trafic reveals marked differences. Only very small quantities of cotton-seed were shipped from the Uganda ports sited on the lake coast of sputhern Buganda, and the bulk of the cotton-seed from the ginneries of the Lake Province of Tanganyika was shipped to Mwanza. In Uganda the total production of cottonseed in 1952 was 133,807 tons, of which Katebo shipped 203 tons, and Bukakata 405 tons, both consignments being sent to Kilindini harbour for overseas shipment.

Within Uganda the sale of oilseeds was controlled in 1952, and the dis- 
tribution of cotton-seed allocated after consideration of the total of the annual yield. Much of the seed is carried by lorries to railhead, the cost of transport being allowed for in the purchase price of the seed. In 1952 the disposal of the seed surplus to that required for planting and ginnery fuel purposes was twofold; tenders were invited from oil millers, who it was hoped would then produce enough oil and cake to satisfy the needs of East Africa, and secondly, the balance was sold by auction or exported to the British Ministry of Food. Thirty-six millers crushed cotton-seed in 1952, using 77,068 tons of seed, the average rate of oil extraction being about 28 gallons per ton of seed. The oil is exported in tank waggons, and insufficiency in the number of these waggons creates difficulties in moving the product. Approximately 1,850,300 gallons of oil were produced in 1952 by the mills, and were distributed as follows :-980,000 gallons to Kenya, 485,904 gallons to Tanganyika and overseas, 282,824 gallons consumed locally and 236,974 gallons carried over to 1953 as a balance. The oil is used principally as a food, though a small and varying quantity is used for soap manufacture. Of the rest of the seed approximately 20,000 tons were retained for local planting, 3,767 tons were used by ginneries as fuel, and 29,017 tons were exported to the Ministry of Food of the United Kingdom. As a result of crushing, 31,522 tons of cotton-seed cake were produced, of which 7,928 tons were allocated to the Kenya Stockfeed Control and 2,090 tons were used locally.

In all this movement rail transport is predominant, and the lake craft play a very minor role in moving the Uganda produce. The movement of cotton-seed from the cotton area in the Lake Province of Tanganyika was during 1952 almost entirely to Mwanza where all seed surplus to planting requirements was sold by auction. Small movements such as 76 tons of seed sent from Mwanza to Mwanyire were probably to augment supplies of seed for planting purposes, whilst other small movements were to the European farming areas of Kenya for cattle feed.

Soap manufacture in the lake area uses both oil extracted from cottonseed and coconut oil imported from the coast. Soap works exist in Kisumu and Musoma, whilst the sugar factory at Kakira also has a subsidiary plant which makes soap.

\section{The Ghee Trade}

Ghee and clarified butter are articles of value in the trade of Lake Victoria, but the traffic is too small for it to be satisfactorily mapped. They are commodities which are greatly in demand amongst Indians and Africans for cooking purposes. The bulk of the ghee production is in the Lake Province of Tanganyika and the South Nyanza District of Kenya. A certain amount is made in Central Nyanza, but none enters into lake traffic.

One important centre is Homa Bay, an outlet for the cattle country in the western parts of South Nyanza, where large plains are suitable for cattle pasturing. Others are Shirati for the cattle area of North Mara, and Musoma for the large cattle region south of the River Mara. In the three districts of South Nyanza, North Mara and Musoma, it has been estimated that there are close upon one million head of catth. These areas with their good rainfall, flowing rivers, access to Lake Victoria, together with plentiful grazing and a type of cow superior to that found in most other areas, are particularly suited to a native dairy industry. ${ }^{1}$

An outline of the ghee industry of Musoma District has been given in Chapter Two. In 1941 a licensing system was introduced and rules laid down for the manufacture of ghee. Before an applicant for a licence is registered

1. Tanganyika Territory: Ammal Repart of the Veterinary Department 1950. 
he must pass through a "ghee school" where he is taught the process of making the first-class product. This has the effect of increasing the price of Musoma produce and has encouraged development of the industry. Under European instruction remarkable results have been obtained in the Districts of North Mara and Musoma. In 1952, 98 per cent. of the North Mara output was of sufficient standard to be graded as clarified butter, a fact made more remarkable when it is realised that the bulk of the produce is made by 1,100 operators using their own separator units. In 1952 the value of ghee and clarified butter produced by these districts was $£ 121,000$, a figure which should be set against the total value of $£ 153,221$ for the whole of the Lake Province.

The bulk of the Musoma ghee comes from the interior of the district, where the people are pastoral by inclination, and not from the coastal belt. Furthermore, since the lake is the chief means of disposing of produce, distance from the lake involves the cost of motor transport. This is expensive and tends to discourage the growth of bulky crops at any considerable distance from the lake. The result is that the lake shore is agricultural, though not so well favoured from the point of view of rainfall as the interior, which remains pastoral. Good quality ghee commands a price which can stand the cost of transport. The one exception to this statement is the Kinesi area, the chief centre of the Suba Federation of Chiefdoms, where the Luo are dominant amongst the population and where cattle are the main interest of the people. It is also a poor area for agriculture.

The role of the dhows in smuggling ghee from Tanganyika to Kenya in the later years of the 1939-45 war has been described in Chapter Three. Smuggling by lorry and dhow has continued and in 1951 because of the very much higher prices to be obtained in Kenya it was estimated that between 800 and $1,00036-1 b$. tins per month were lost by this illicit traffic. As a result of the very much higher prices for ghee in both Uganda and Kenya there was an increase in 1953 in the quantity of low-grade ghee produced. This is because low-grade ghee may be exported and it is sufficiently attractive financially to downgrade ghee with a view to obtaining an export permit. There has been a tendency in recent years for more of the poor "kibuyu" type of ghee to be made in Sukumaland, especially in Mwanza District.

The bulk of the ghee produced in Tanganyika is sent through the Control Board to the chief towns in Tanganyika, particularly to Tanga and Dares-Salaam. Of the 446 tons shipped from Musoma in 1952, 150 tons were sent to Dar-es-Salaam, 118 tons to Tanga, 54 tons to Moshi, 34 tons to Bukoba and 20 tons to Mwanza. The Kenya product likewise finds its market in the Indian communities of the larger settlements, such as Nairobi, Nakuru, Mombasa and Kisumu. Homa Bay in 1952 shipped 357 tons of ghee, 166 tons being sent to Mombasa, 162 tons to Nairobi, and 33 tons to Nakuru. Kendu Bay sent the whole of its produce of 28 tons to Kisumu.

\section{The Groundnut Trade}

Groundnuts are grown in African plots in all the districts around Lake Victoria as an additional item to the diet of the people. It is only in a few areas that there is any excess available for export. The most important area with a surplus crop is found as a belt about 12 miles wide along the southern shore of the Kavirondo Gulf. The crop is handled in almost equal bulk at Homa Bay and Kendu Bay; in 1948 the tonnages handled were respectively 736 tons and 654 tons, but these had fallen in 1952 to 406 and 302 tons, because prices at planting time were unattractive to the growers. Except for small quantities, all the groundnuts which are exported from this area go to oil mills in Kisumu, where they are crushed and groundnut oil extracted. 
Musoma is another exporting centre of groundnuts, the bulk of the crop originating in the middle belt of the Musoma region, in what is the territory of the Zanaki. In this well-wooded country the bush is lopped, leaving stumps about two feet above the ground. After the crops are reaped, the stumps shoot again and in this way the natural vegetation of the area is largely preserved together with shade and shelter.

Groundnuts are a common crop in the Mwanza area and are often planted amongst the cereals, especially between maize. As a rule they are grown on the lighter soils and avoid the heavier clays. The production of groundnuts in Sukumaland, as in many other parts of the lake basin, is still considered very largely to be a prerogative of the women. Oil mills exist in Mwanza for crushing the nuts, and much of the crop which is marketed is sold to the mills for export as oil.

\section{The Oil Seeds, Beans, and Tobacco Trades}

Brief mention should be made of a number of other commodities carried as lake traffic by the craft of the East African Railways and Harbours system. Oil seeds, mainly castor seed, with some sunflower seed, are a valuable cargo shipped from Bukakata, which in 1952 sent 3,619 tons to Kilindini Harbour for overseas export. The bulk of this production was from Masaka District which in 1952 marketed 4,337 tons of castor seed worth $£ 242,872$. Smaller quantities were also forthcoming from Ankole and Kigezi Districts. Shipments of oil seeds varying from 50 to 100 tons were sent from Musoma, Mwanza, Nyamirembe and Nungwe to Dar-es-Salaam for overseas export.

Beans, both mixed and of the soya variety, are a bulky cargo which figured in 1952 in the traffic through the ports of Bukoba, Mwanza and Bukakata. These ports handled respectively 2,262 tons, 1,287 tons, and 291 tons. Soya beans, grown in the Karagwe area of western Bukoba District, formed the bulk of the cargo shipped from Bukoba. Unfavourable weather conditions affected the size of the bean crop in Masaka and Ankole Districts, yields being markedly decreased in comparison with other years, as shown by a comparison with 1948, when Bukakata shipped 899 tons of beans. Mixed beans formed the bulk of the cargo shipped from Mwanza. With the exception of small loads sent to various urban areas in East Africa, the greater proportion of the bean traffic through these ports was to the ocean terminals of Mombasa and Dar-es-Salaam.

Tobacco, both raw and processed, is a commodity of value in lake trade, though not one of great bulk. The largest consignment of raw tobacco was from Iringa in the Southern Highlands Province of Tanganyika, which sent 1,112 tons of flue-cured tobacco to the factories in Jinja, Nairobi and Kampala. Fire-cured tobacco grown by native growers in the Kibondo, Ngara and Biharamulo Districts of the Lake Province of Tanganyika was processed at the premises of the Nyamirembe Native Tobacco Board, 146 tons then being shipped to Kampala. Another large source of tobacco was the Overseas Food Corporation unit at Urambo which in 1952 sent 62 tons to the East African Tobacco Company at Kampala. A small but interesting trade is that between the Embu people of Kenya and the inhabitants of South Nyanza and North Mara Districts. Small consignments.of broken leaf tobacco were sent from Sagana, Nyeri and Karatina stations to Kendu Bay, Homa Bay, Mohoru Bay and Shirati, the leaf being bought by local agents on behalf of buyers in these areas.

Cigarettes and processed tobacco from the tobacco factories in Nairobi, Jinja and Kampala move across the lake to Tanganyika towns in the Lake Province and to distribution points along the Central Railway line. The largest consignments were from Jinja and Kampala, 252 tons and 116 tons respectively, only 14 tons being railed from Nairobi to points across the lake. 


\section{The Fishing Industry}

It remains to outline some of the aspects of the fishing industry of Lake Victoria, an industry for which as yet no firm statistics are available. Although the lake contains various edible fish, one group, Tilapia spp., which is excellent to eat, is pre-eminent and forms the basis of much of the fishing.

A report was made upon the fisheries of Lake Victoria as long ago as 1927-28, ${ }^{1}$ but it was not followed up, and little was done to tap the wealth of fish in the lake scientifically or to protect the fisheries from over-exploitation. It was not until the Inter-territorial Organization was established in East Africa in 1948 that a Lake Victoria Fisheries Service was set up, together with the East African Inland Fisheries Research Organization.

Fishermen using indigenous methods of fishing, e.g., traps, baskets and fences are not licensed and it is therefore impossible to assess completely the number of people engaged in fishing, but there are certainly more than 30,000 , all of them African, though some nets and boats are owned by Asians. Both the western and eastern sides of the lake show migratory movements of fishermen. Periodically, fishermen from the Sese Islands move south to the mouth of the Kagera River, whilst along the eastern coast Luo are to be found in fishing encampments as far south as Mwanza. The common practice of the Luo is for a group of fishermen to take two small dhows and four or five canoes. The men then run a shuttle service between the fishing ground and the Kavirondo Gulf. The fish are crudely dried and packed in wicker baskets. One dhow is loaded with dried fish and sent back to the Kavirondo Gulf with a skeleton crew, whilst the other fishermen continue to fish, and to load the second dhow. Dried fish find a ready market amongst the dense population in the Nyanza Province. In Uganda also, particularly during the cotton selling season when extra money is available for such luxuries, dried fish have a ready sale. Considerable quantities of dried fish are bought annually on the Buganda mainland from the Sese Islands and the Kagera River.

The fresh fish industry is only organized to any extent in the Kisumu area; lack of communications prevents fishermen in many areas from selling their fresh fish. Many of the fishermen are coastal people who fish primarily for their own needs and dry any surplus catch. Modern methods of fishing by using nets were introduced in 1905, but many primitive methods of fishing still survive. The supply of fresh fish is a great attraction to many of the lake-side dwellers, particularly along the Musoma coast. In Majita, despite the rapid exhaustion of the soil and the inability of the land to support the population, there is a great reluctance on the part of the people to move out of the area to new lands prepared for them by the Government as it would involve a loss of contact with the lake. Fish is an important part of the Jita diet which is lacking in animal and stock products. Fishing with seine nets around the Majita peninsula yields on an average estimate 65 tons of fish per seine net per annum. There are as many as ten seine nets in use in this area. ${ }^{2}$

The nature of the climate, and the present primitive boats, mean that fresh fish cannot be caught at any great distance from their market. The bulk of the fresh fish which passes through Kisumu is caught in or close to the Kavirondo Gulf. A private enterprise, Lake Fish. Distributors, owning a cold storage plant, purchases the fish from the fishermen and rails the fish to Nairobi. The catch is landed in the early morning and taken by lorry to Kisumu where fish for sale in the town are sold, the rest are kept until the late afternoon, by which time the catch from the more distant points has been brought into Kisumu. Then the fish, all "ngege", a species of Tilapia, are

1. M. Graham. The Victoria Nyanza and its Fisheries: A Report on the Fishing Survev of Lake Victoria

2. East Africa High Commission : Lake Victoria Fisheries Service Ammal Report 1953. p. 2. 
gutted and crated in ice and rice husks obtained from the nearby mills and sent by the night train to Nairobi and Nakuru, the principal European settlements along the line. The quantity railed to Nairobi in 1952 was 2,342,175 fish, approximately 1,500 tons, or some 6,000 fish per day. In addition quantities of fish are sent away by bus and by bicycle.

No figures are available for the value of the fish caught around the shores of the whole lake, but some guide to the size of the industry can be obtained from the estimate made in 1953 by the Lake Victoria Fisheries Service of the value of fishing gear then in use. ${ }^{1}$ The value of the nets used during the year was put at $£ 760,000$, representing recurrent expenditure, and the value of craft at $£ 160,000$, making a total value for all gear used of $£ 920,000$. The estimate was based on the use of some 250,000 5-in. gill nets, a smaller number of small-mesh gill nets, 4,000 seine nets, 600 "karuas" and 5,000 canoes.

Sufficient has been said to show that there is a very large and valuable market for both fiesh and dried fish from Lake Victoria. The establishment of a Lake Victoria Fisheries Service to control the whole of the lake was a measure long overdue. Its duty must be both to foster the organization of the fishing industry in order to provide a far greater supply of fish for the numerous population around the lake, and to safeguard those fishing grounds which are still rich in fish from suffering the depletion which is now most probably a permanent feature of the Kavirondo Gulf.

\section{The Trade in Imported Goods}

The character of the trade in imported goods reflects the position that the Lake Victoria zone is an area producing primary products and that there is no large-scale production of manufactured goods within the region. It is true that around the larger towns of Kisumu, Kampala and Jinja there are small industrial units, soap works, tobacco factories, brickworks, limeworks, etc., but apart from the alimentary industry of sugar-making there is a lack of any major industrial development. The Jinja-Kampala belt of country will become a small industrial region, but that is development which will probably spread over the next decade.

The imports of the Lake Victoria zone vary little in character from one portion to another : the wants of Bukoba are very much the same as those of Musoma or Mwanza, or of the many small ports around the lake shore. The purchasing power of the people is controlled by the agricultural wealth of the region in which they live; the people of the richer north-western shores with their profitable crops of cotton and coffee have the ability to buy more than those people in the drier and less productive regions of the southern and eastern shores, but their imports in kind, if not in quantity and quality, remain very much the same.

In the country districts, almost without exception, the import trade is in the hands of Indians. There are a few Arab traders, but they tend to be found in more remote spots and very often only where there is no Indian competition. Even in the larger towns, although there is a sprinkling of European traders, the bulk of the commercial life is Indian. Their small shops very often stock an incredible range of imported goods, a fact especially true of the country shops.

\section{?.}

Customs returns at the individual lake ports do not record imports from overseas which are handled at the ocean ports of entry into East Africa, but record only those goods imported from the other territories in East Africa. It is not possible to extract from the total import figures published for each territory the quantity and value of goods imported from abroad

1. East Africa High Commission: Lake Victoria Fisheries Service Aumual Report 1953, p. 3. 
into the lake zone as distinct from the territory as a whole, but to this class belong such commodities as cotton-piece goods, kerosene, petrol, bicycles and other manufactured iron and steel goods.

Imports into the Lake Victoria zone from the East African territories are mainly foods or processed agricultural products, tea from either Kenya or Uganda, sugar, tobacco and cigarettes from Uganda, jaggery and maize flour from Kenya. Other items may include articles manufactured in some of the towns in Kenya, such as shoes from the Bata factory, sisal bags, and woollen blankets from the small mill in Nakuru. The non-native element in the population is responsible for the inclusion of such items as bacon, butter and lard from the European dairy farms of Kenya, beer from the Nairobi and Kampala breweries, wheat flour and simsim oil from the Kenya mills.

The customs returns at Bukoba of goods imported from Kenya and Uganda in 1948 are typical of the inter-territorial trade. With the exception of sugar, tobacco and cigarettes, and a little tea, all the goods came from outside the lake region. Foodstuffs imported in 1948 were 129 tons of wheat flour, 264 tons of sugar, $152 \mathrm{cwt}$. of tea, $74 \mathrm{cwt}$. of butter, and $621 \mathrm{cwt}$. of salt, worth respectively $£ 3,913, £ 5,525, £ 1,586, £ 853$ and 2264 . Manufactured goods included $81 \mathrm{cwt}$. of aluminium African cooking pots, $52,395 \mathrm{lbs}$. of cigarettes, and $871 \mathrm{cwt}$. of sisal bags, valued respectively at $£ 1,461, £ 47,371$, and $£ 5,946$. In the 1947 returns there figure 301 dozen pairs of shoes and 1,200 gallons of beer.

\section{Conclusion}

Something has been said of those differences which exist between one part of the Lake Victoria basin and another, and sufficient to show that Lake Victoria has not yet bound the peoples around its shores into a common community. There is little local trade between the various parts of the lake; and thinking in terms of the traditional African societies which have their homes in the Lake Victoria zone, nothing which might be termed a common culture has developed around the shores of the lake. It is not surprising that there should be this lack of unity. Primitive craft, the primitive wants of society, the width of the lake, the violence of the lake storms, the great tracts of fly-infested bush would all militate against any long and sustained intercourse between one region of the lake and another, either by water or overland. The advent of the Europeans and the Asians has not resulted in any very great interchange of goods from one part of the lake region to another. Their intervention in African economy has not produced articles of commerce, other than sugar and tobacco and cigarettes, which enter greatly into local trade between the various marginal lands of the lake. It is the transit traffic between the two outlets of Kisumu and Mwanza which is of overwhelming importance, and for the majority of the people the lake is a medium connecting them with the outside world and not with other parts of the lake margins. The bulk of the export and import trade of all the ports is in goods destined for and originating from the extra-lacustrine areas. It is the transit nature of the trade of Lake Victoria, tingether with the political division of the lake, which has given rise to various problems affecting trade. To appreciate these problems it is necessary to set Lake Victoria and its marginal lands against the general pattern of East Africa. When this is done it is seen that around the lake shores is one of the densest concentrations of population in East Africa, and that from the marginal lands important export commodities, such as cotton and coffee, are produced in large quantities. Despite the diversity of its lands, the Lake Victoria zone assumes an economic unity as a region productive of valuable export commodities, but 
cutting across this unity have been the frontiers between Kenya, Uganda and Tanganyika.

In this last respect 1948 inaugurated a new period in the history of the trade of Lake Victoria. For forty-six years the lake was under a divided transport service, but now with the establishment of the East African Interterritorial Organization and its transport, customs and fisheries services, Lake Victoria with its marginal lands can look forward to a new period during which its potentialities as an economic and geographical unit may for the first time be fully developed. 


\section{SELECT BIBLIOGRAPHY}

Colony and Protectorate of Kenya, Department of Agriculture. Annual Reports. Nairobi : Government Printer.

Colony and Protectorate of Kenya. Report of the Board under the Chairmanship of Sir William Ibbotson on the Marketing of Maize and other Produce. Nairobi : Government Printer, 1952.

East Africa High Commission. Lake Victoria Fisheries Service Ammal Reports 1952 and 1953. Nairobi : Government Printer.

East Africa High Commission. East African Economic and Statistical Bulletin, No. 1. September, 1948, et seq. Nairobi : Government Printer.

East African Railways and Harbours. Reports of the Commissioner for Transport, East Africa High Commission, and the General Manager on the Administration of the East African Railway's and Harbours. 1948 et seq. Nairobi : Government Printer.

Edwards, D.C. “A Vegetation Map of Kenya, with particular reference to Grassland Types", Journal of Ecology, Vol. XXVIII, 1940.

Farquharson, J. R. Tanganyika Transport: A Review. Dar-es-Salaam : Government Printer, 1945

Ford, V. C. R. "The Trade of Lake Victoria and its Marginal Lands", Geographical Essays on British Tropical Lands, ed. R. W. Steel and C. A. Fisher. London : George Philip and Son, 1955.

Ford, V. C. R. " Some Factors affecting the trade of the Lake Province of Tanganyika ", XVIIth International Geographical Congress, Publication No. 6. Washington? International Geographical Union, 1952.

Gillman, C. "A Population Map of Tanganyika Territory", Geographical Review, Vol. XXVI, 1936.

Gillman, C. "A Vegetation-Types Map of Tanganyika Territory", Geographical Review, Vol. XXXIX, 1949.

Graham, M. The Victoria Nyanza and its Fisheries : A Report on the Fishing Survey of Lake Victoria, 1927-1928. London : Crown Agents for the Colonies, 1929.

Great Britain. Report by Mr. Roger Gibb on Railway Rates and Finance in Kenya, Uganda and Tanganyika Territory'. Cmd. 4235. London: H.M.S.O., 1932.

Hailey, The Lord. An African Survey. 2nd Edition. London: Oxford University Press, 1948.

Henderson, J. P. Some Aspects of Climate in Uganda with Special Reference to Rainfall. East African Meteorological Department. Memoirs, Vol. II, No. 5. Nairobi : 1949.

Hill, M. F. Permanent Way-the Story of the Kenya and Uganda Railway. Nairobi : - East African Railways and Harbours, 1950.

Humphrey, N. The Liguru and the Land. Nairobi : Government Printer, 1947.

Kenya and Uganda Railways and Harbours. Reports of the General Manager on the Administration of the Kenya and Uganda Railway's and Harbours, 1926-1947. Nairobi : Government Printer.

Malcolm, D. W. Sukumaland, An African People and Their Country. London : Oxford University Press, 1953.

Mance, Brigadier-General Sir H. O. Report on the Co-ordination of Transport in Keny'a, Uganda and the Tanganyika Territory. Nairobi : Government Printer, 1937.

Matheson, J. K. and Bovill, E. W. East African Agriculture. London : Oxford University Press, 1950.

Milne, G. "Essays in Applied Pedology. III. Bukoba. High and Low Fertility in a laterised Soil, and including a note on Soil Fertility at Nyakato by A. H. Savile. C.D.A.", East African Agricultural Journal, Vol. IV, 1938.

Milne, G. A Provincial Soil Map of East Africa (Kenya $a_{\dot{q}}$ Uganda, Tanganyika and Zanzibar) with explanatory memoir. Amani Memoirs. Crayn Agents for the Colonies, 1936.

Richards, A. I. ed. Economic Development and Tribal Change. A Study of Immigrant Labour in Buganda. Cambridge : Heffers, 1954.

Rounce, N. V. The Agriculture of the Cultivation Steppe of the Lake, Western and Central Provinces. Department of Agriculture, Tanganyika Territory. Longmans, 1949.

Rounce, N. V. and Thornton, D. Ukara Island and the Agricultural Practices of the Wakara. Nairobi : Government Printer, 1948.

Tanganyika Territory, Department of Agriculture. Agriculture in Tangamyika. Dar-esSalaam : Government Printer, 1945. 
Tanganyika Territory, Department of Agriculture. Anmual Reports. Dar-es-Salaam : Government Printer.

Tanganyika Railways and Ports Services. Anmual Report of the General Manager on the Tanganyika Rail and Ports Service, 1939. Dar-es-Salaam : Government Printer, 1940.

Thomas, H. B. and Scott, R. Uganda. London : Oxford University Press, 1935.

Tothill, J. D. ed. Agriculture in Uganda. London : Oxford University Press, 1940.

Uganda Protectorate, Department of Agriculture. Anmual Reports. Entebbe : Government Printer.

Uganda Protectorate. Anmual Report of the Department of Commerce, 1952. Entebbe : Government Printer, 1953.

Uganda Railway. Anmual Reports of the General Manager of the Uganda Railway, 1905-06 to 1925. Nairobi : Government Printer.

Walter, A. "The Climate of Uganda with Special Reference to the Agricultural Districts," Section II, Agriculture in Uganda, ed. J. D. Tothill. London : Oxford University Press, 1940 


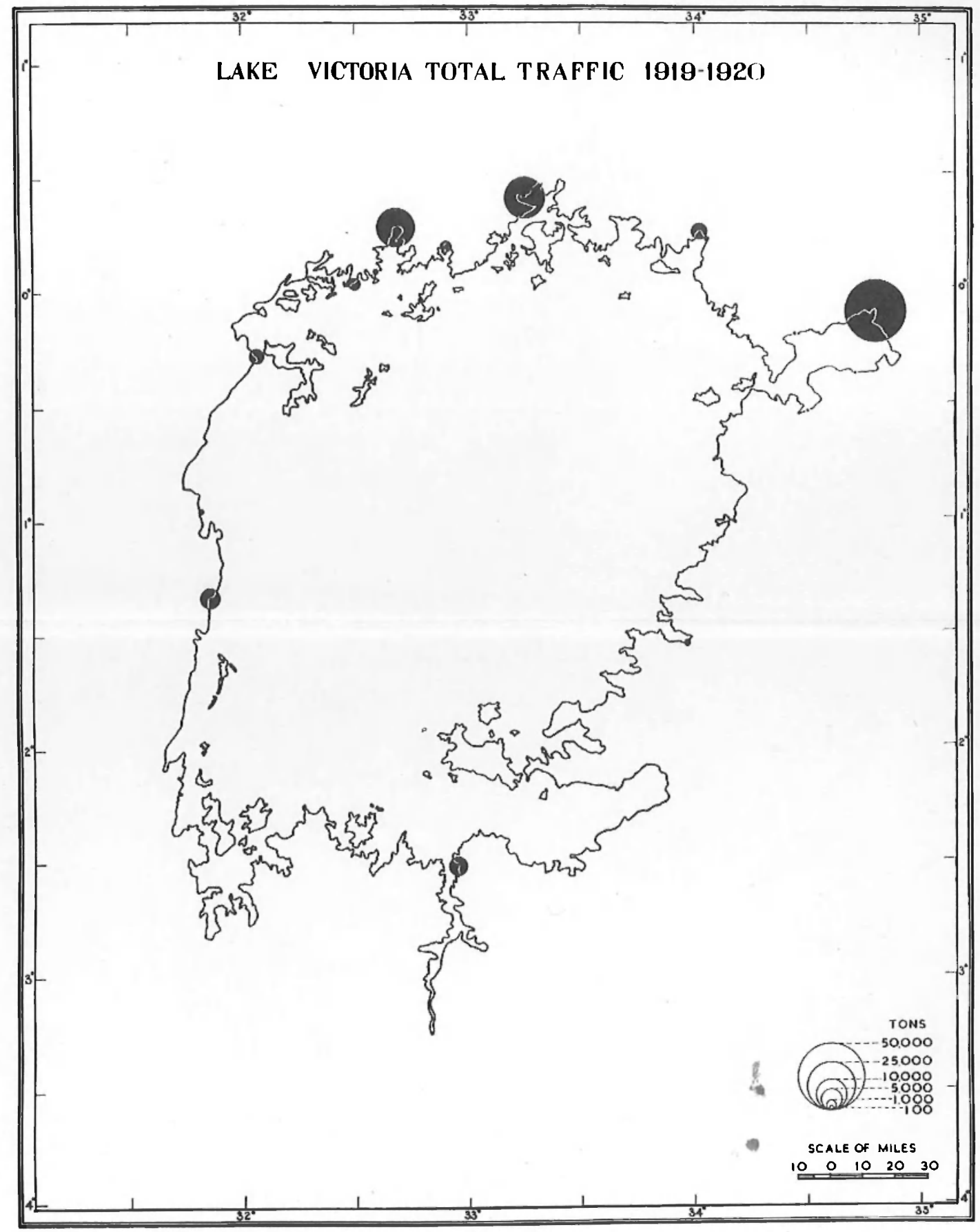

Figure 3. 


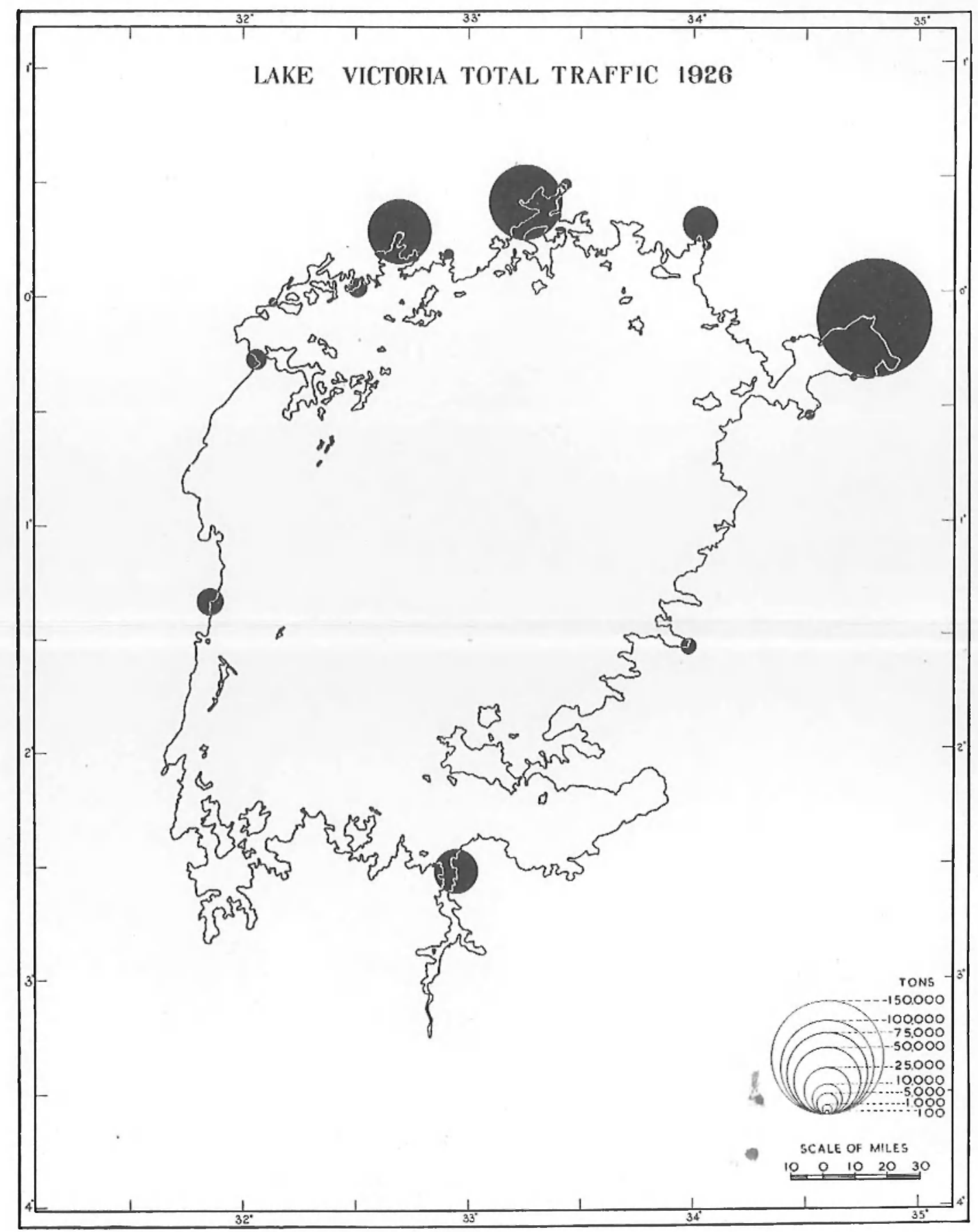

Figure 4. 


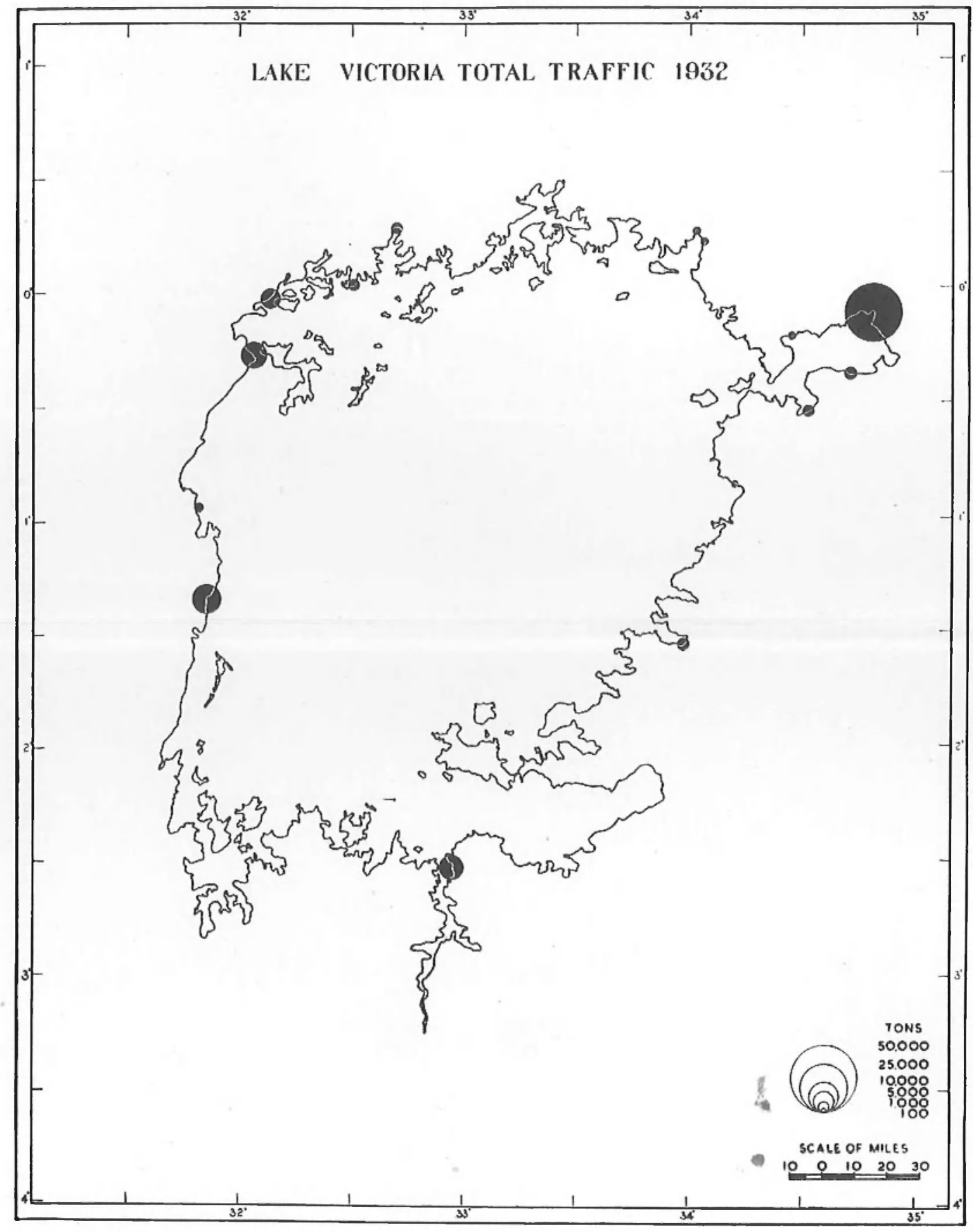

Figure 5. 


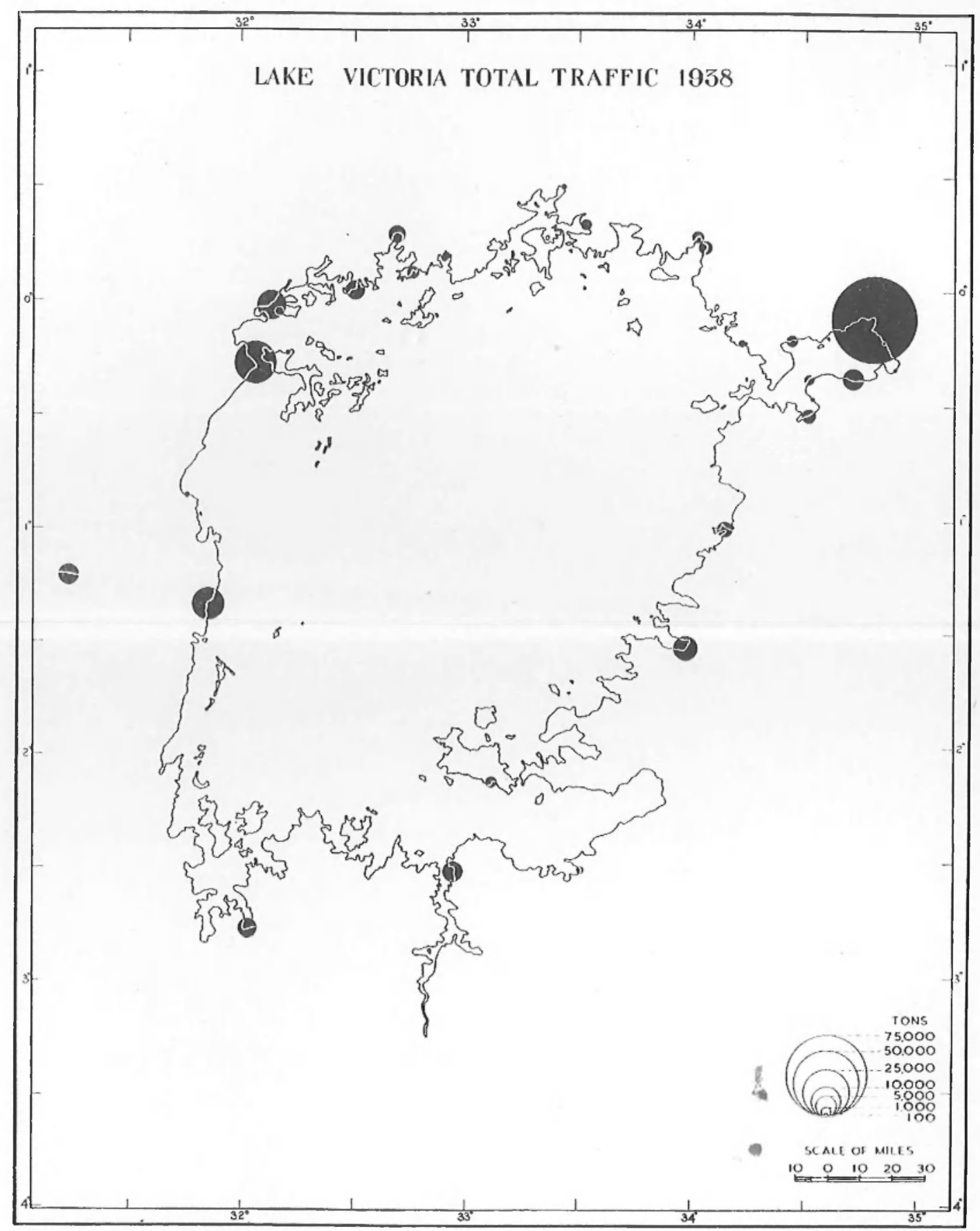

Figure 6. 


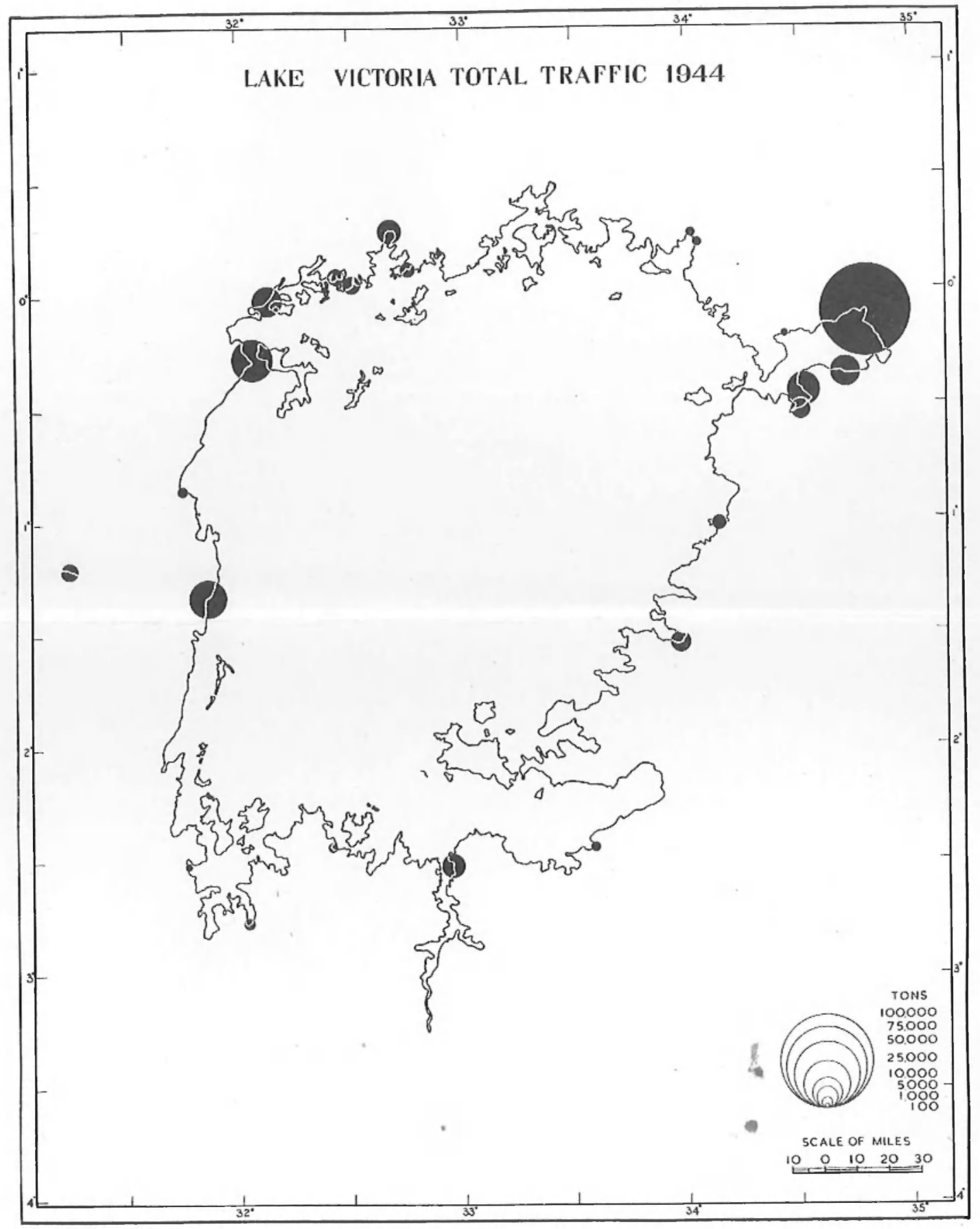

Figure 7. 


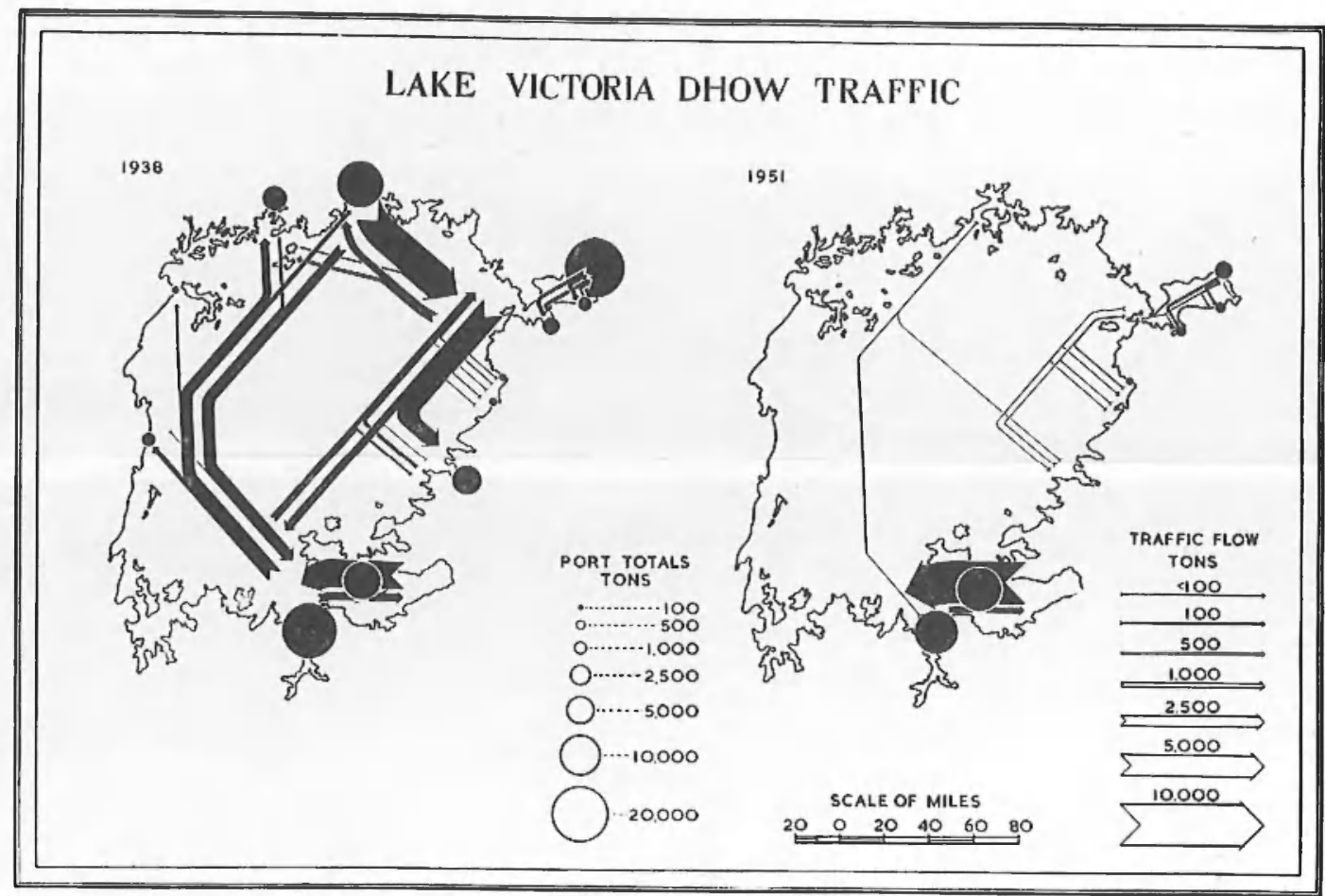

Figure 8. 


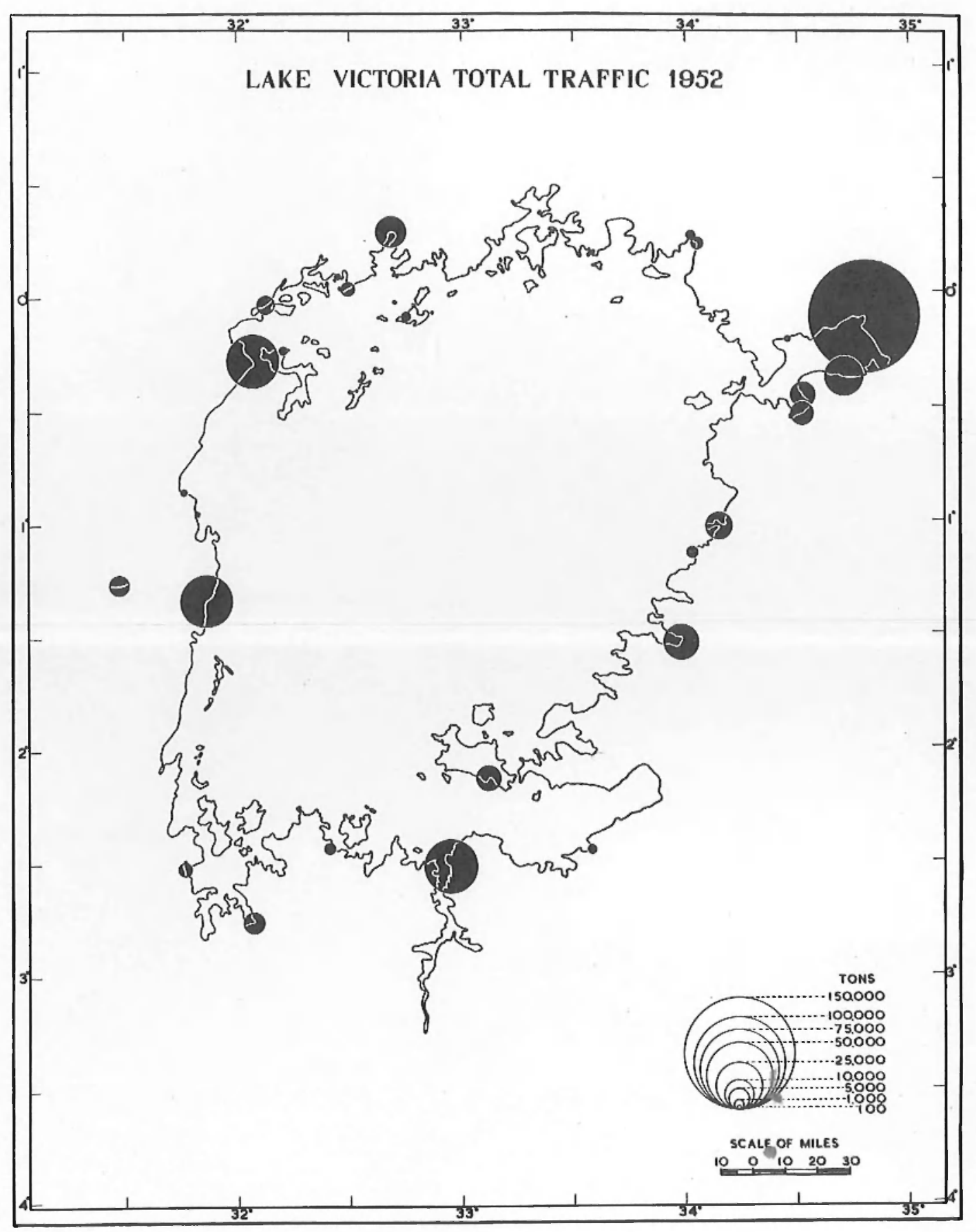

Figure 9. 


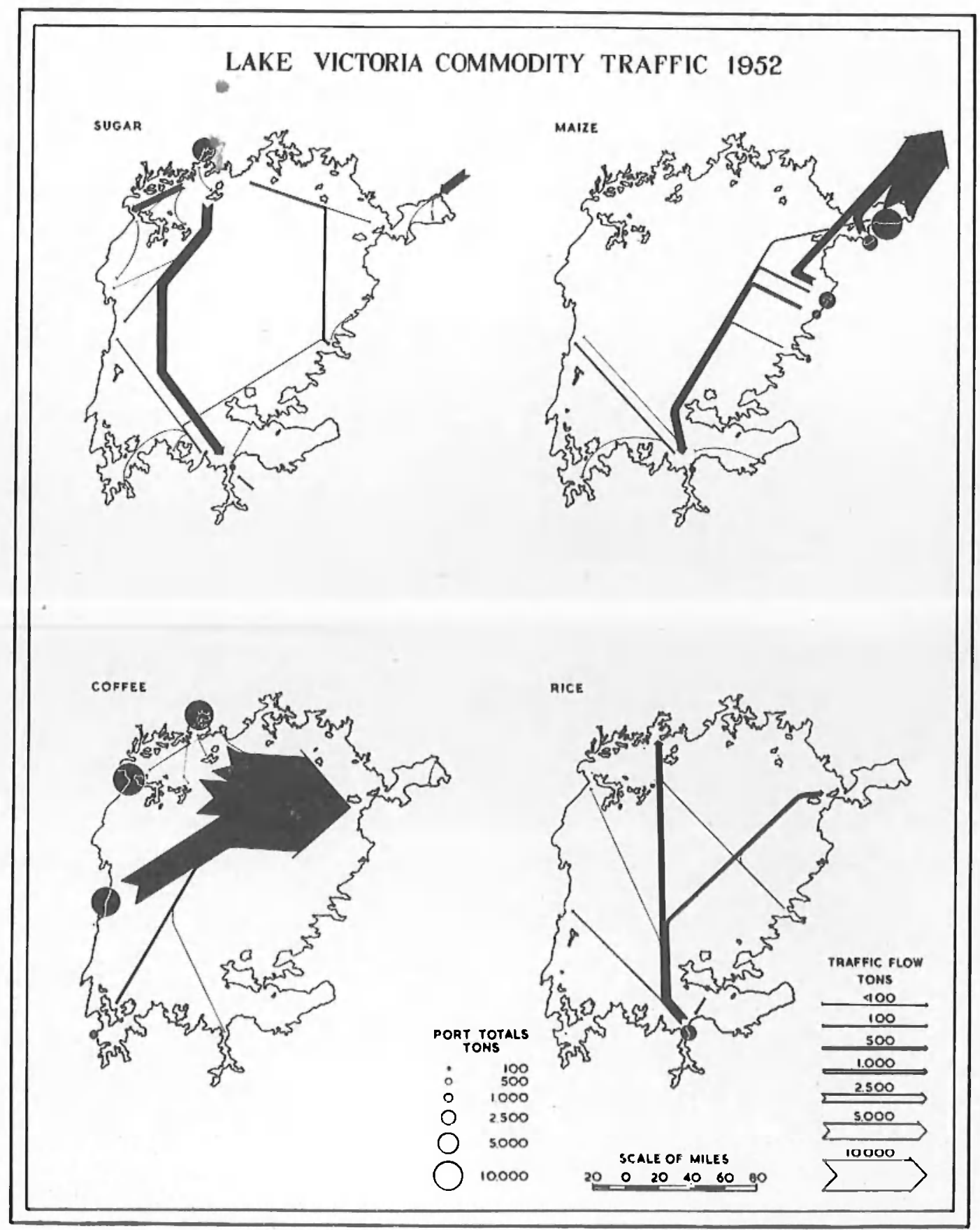

Figure 10.

The above maps, together with those in Figure 11, have been compiled from the detailed code records which are kept by the East African Railways and Harbours of all consignments handled by their services. 


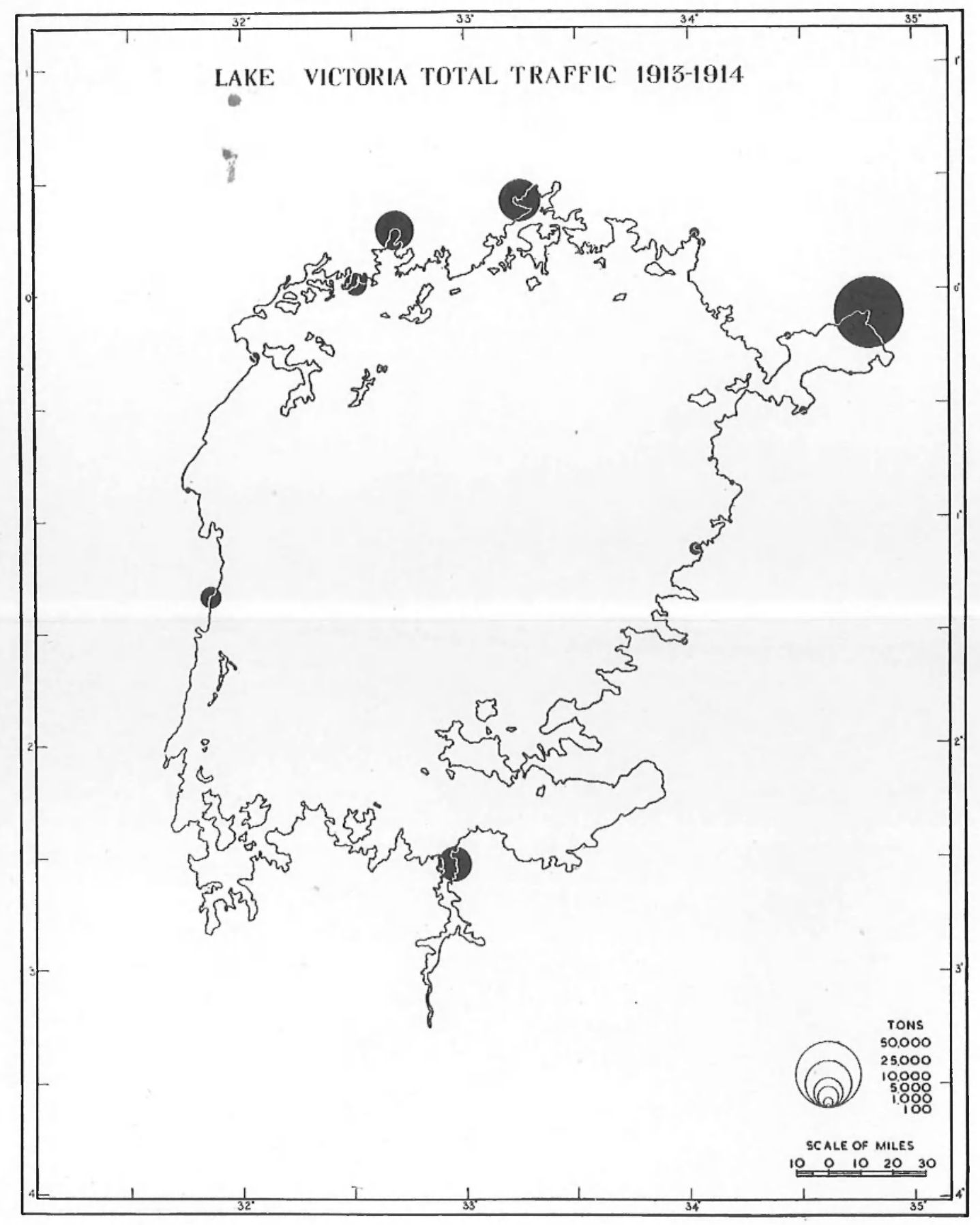

Figure 2. 


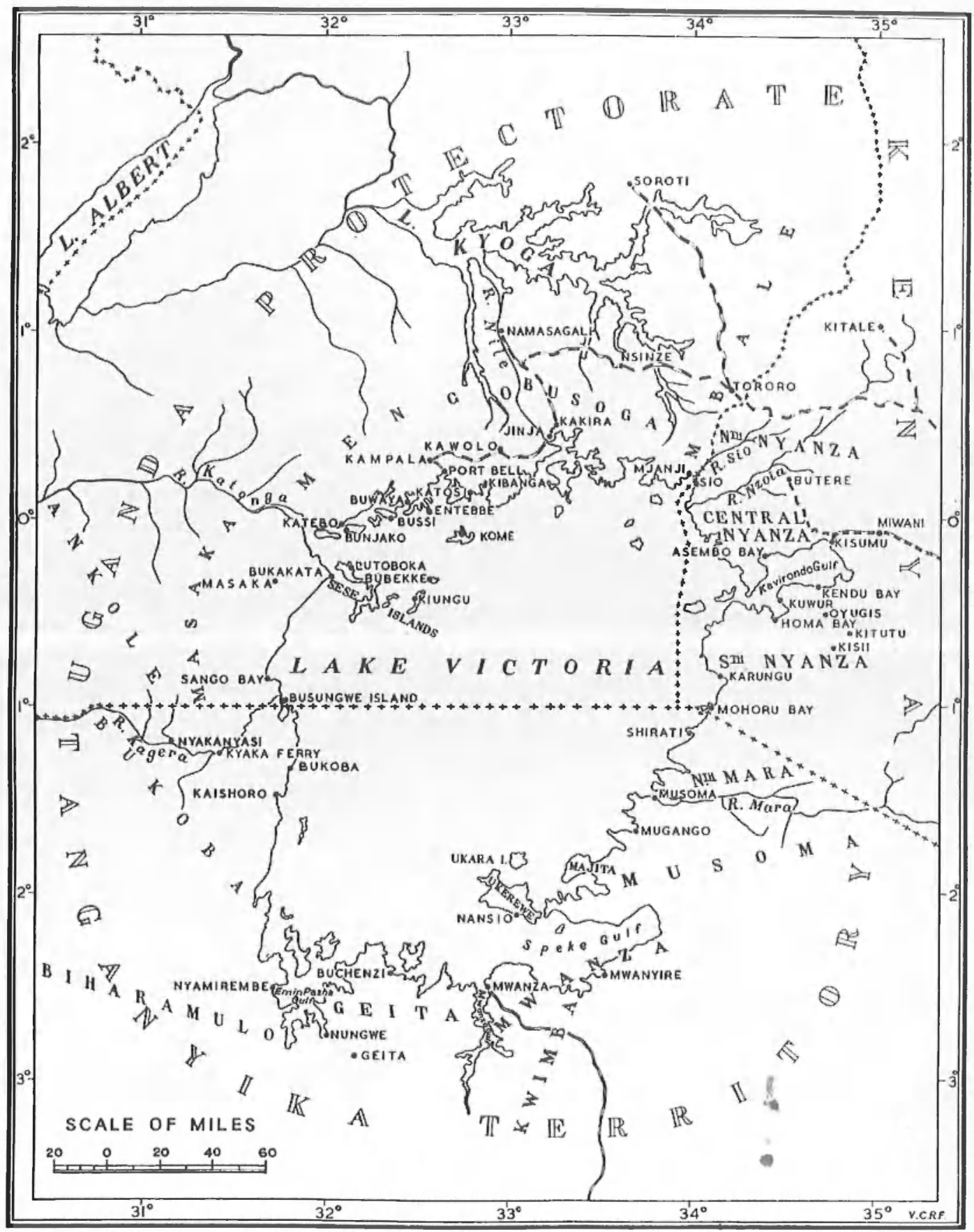

Figure 1.

The Lake Victoria Basin : principal lakes and rivers, ports, other place names, railways and inter-territorial boundaries. 
This work is licensed under a

Creative Commons

Attribution - NonCommercial - NoDerivs 3.0 Licence.

To view a copy of the licence please see:

http://creativecommons.org/licenses/by-nc-nd/3.0/ 